INTERNATIONAL MONETARY FUND
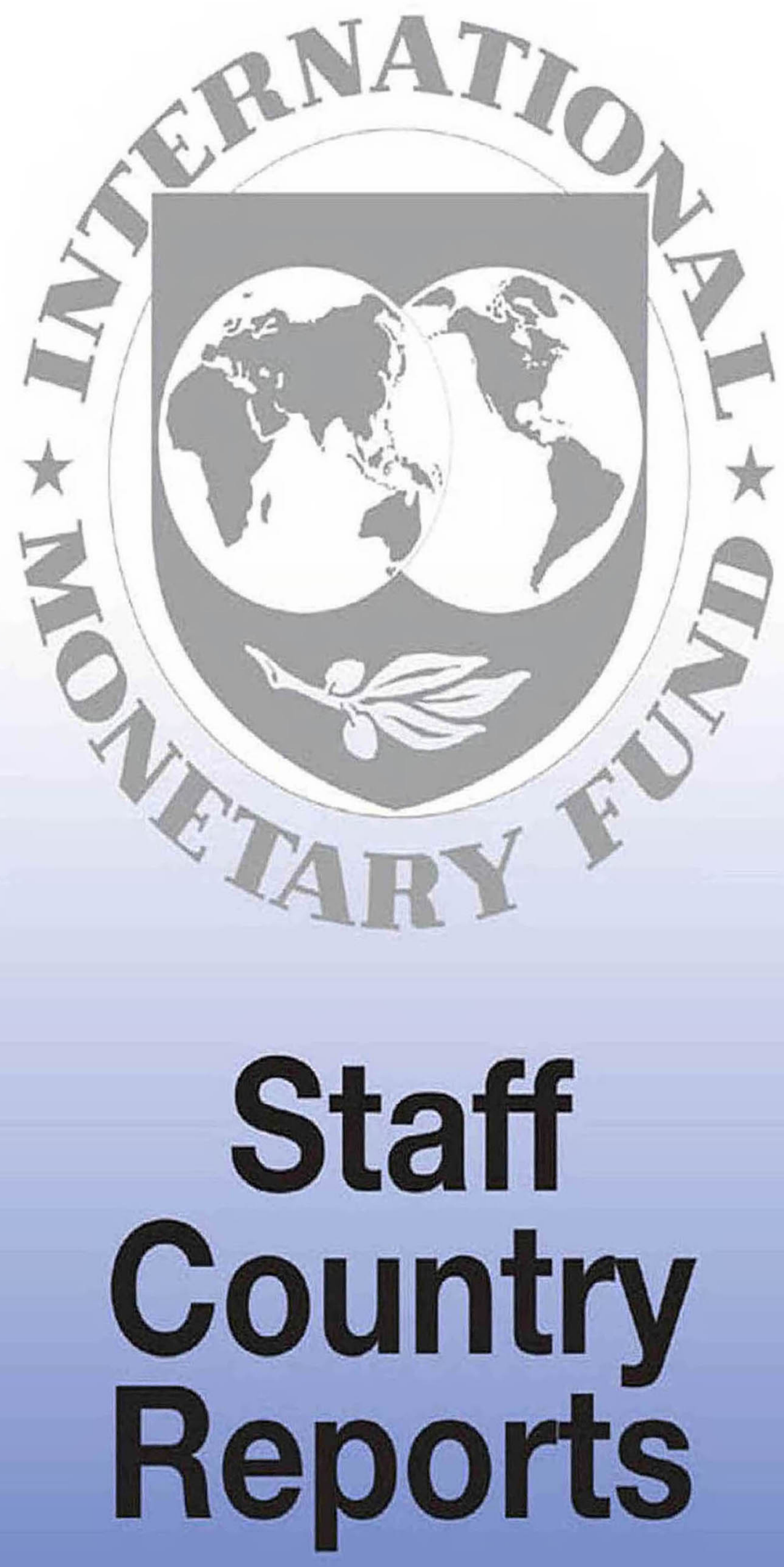


\section{Union of the Comoros: Poverty Reduction Strategy Paper- Review of the Second Year of Implementation}

This paper was prepared by the Comorian authorities as an assessment of progress in implementing their Poverty Reduction Strategy Paper in 2011. It is based on the information available at the time it was completed in October 2012. The views expressed in this document are those of the authorities and reflect the views of the government of Comoros.

The policy of publication of staff reports and other documents by the IMF allows for the deletion of market-sensitive information.

Copies of this report are available to the public from

International Monetary Fund • Publication Services

$70019^{\text {th }}$ Street, N.W. • Washington, D.C. 20431

Telephone: (202) 623-7430 • Telefax: (202) 623-7201

E-mail: publications@imf.org Internet: http://www.imf.org

\section{International Monetary Fund Washington, D.C.}


OFFICIAL TRANSLATED VERSION

\section{Union of Comoros}

Poverty Reduction and Growth Strategy

\section{Review of the second year of implementation}

2011

PRGS Standing Technical Steering Committee

The Government's Economic Advisory Commission

(Commissariat Général au Plan) 


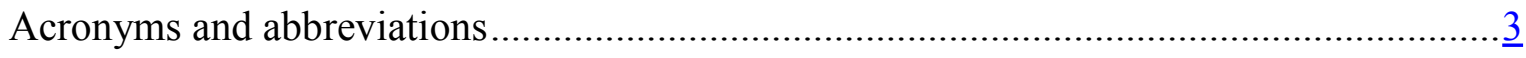

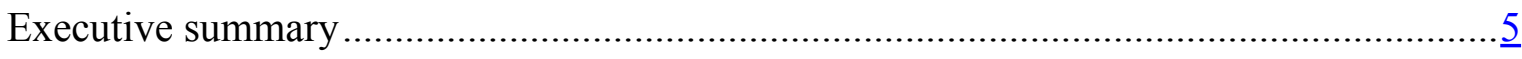

General introduction...................................................................................... 12

I. MACROECONOMIC FRAMEWORK AND SITUATION OF POVERTY ...........14

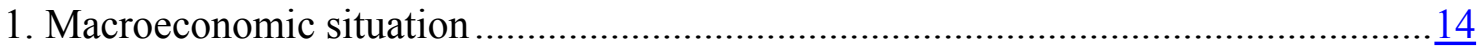

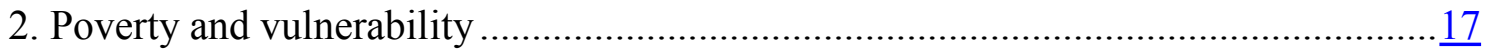

II. IMPLEMENTATION OF THE PRIORITY ACTION PLAN IN 2011 AND

HIPC TRIGGERS...............................................................................................19

Core strategy 1: Stabilize the economy and lay the groundwork for strong growth based on equity .......................................................................

Core strategy 2: Strengthen the profitable sectors by emphasizing institution-building and increased participation of private economic operators ................. $\underline{38}$

Core strategy 3: Strengthen governance and social cohesion .................................... $\underline{53}$

Core strategy 4: Improve the health status of the general public .................................

Core strategy 5: Promote education and vocational training with a view to developing

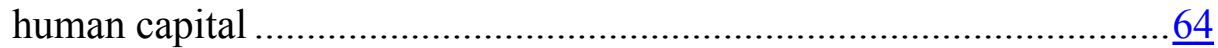

Core strategy 6: Promote environmental sustainability and civil security....................69

III. ANALYSIS OF IMPLEMENTATION AND MONITORING AND

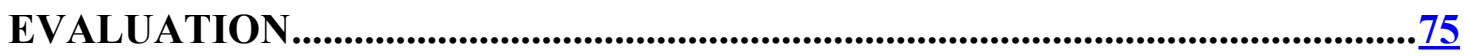

1. The institutional framework for monitoring the PRGS …...................................

2. PRGS implementation and monitoring instrument .........................................

3. Resource mobilization instrument …......................................................

4. Implementation of the Paris Declaration...........................................................

IV. CONCLUSION AND RECOMMENDATIONS FOR 2012 ................................ 


\section{Acronyms and abbreviations}

\begin{tabular}{|c|c|}
\hline AAIA & Arab International Agency for Agriculture \\
\hline ADB & African Development Bank \\
\hline AFD & African Development Fund \\
\hline AFD & French Development Agency \\
\hline AFRISTAT & Economic and Statistical Observatory for Sub-Saharan Africa \\
\hline AGOA & Africa Growth and Opportunity Act \\
\hline AIDS & Auto-Immune Deficiency Syndrome \\
\hline $\mathrm{APC}$ & Apprenticeship by Skills \\
\hline APLACO & Support for Development Planning and Coordination \\
\hline ARV & Antiretroviral Treatments \\
\hline ASCOBEF & Comorian Association for Welfare and the Family \\
\hline $\mathrm{BCC}$ & Central Bank of the Comoros \\
\hline $\mathrm{CCI}$ & International Trade Center \\
\hline $\mathrm{CF}$ & Comorian franc \\
\hline CGP & Office of the Commissioner General for Planning \\
\hline COMESA & Common Market for Eastern and Southern Africa \\
\hline COPSED & $\begin{array}{l}\text { Committee for Development Guidance, Planning and } \\
\text { Monitoring/Evaluation }\end{array}$ \\
\hline COSEP & Emergency Operations and Civil Defense Center \\
\hline $\mathrm{CRC}$ & Convention on the Rights of the Child \\
\hline CREF & Financial and Economic Reforms Unit \\
\hline CRESMIC & Reference Framework and Common Minimum Methodological Guidelines \\
\hline $\mathrm{CSO}$ & Civil Society Organization \\
\hline DAD & Development Assistance Database \\
\hline DCP & Decentralized Cooperation Program \\
\hline DNS & National Statistics Directorate \\
\hline EAC & East African Community \\
\hline $\mathrm{ECF}$ & Extended Credit Facility \\
\hline EDF & European Development Fund \\
\hline EIM & Comprehensive Household Survey \\
\hline EPA & Economic Partnership Agreement \\
\hline EU & European Union \\
\hline FADC & Community Development Support Fund \\
\hline FAO & Food and Agriculture Organization \\
\hline FDA & French Development Agency \\
\hline FIDA & International Fund for Agricultural Development \\
\hline FSF & Fragile States Facility \\
\hline FTZ & Free Trade Zone \\
\hline GAB & ATM machine \\
\hline GAFTA & Greater Arab Free Trade Area \\
\hline GDP & Gross Domestic Product \\
\hline GIZC & Comprehensive Management of Coastal Zone \\
\hline GTS & Sectorial Working Group \\
\hline HIPC & Heavily Indebted Poor Countries Initiative \\
\hline IDB & Islamic Development Bank \\
\hline IFC & International Finance Corporation \\
\hline ILO & International Labor Office \\
\hline IMF & International Monetary Fund \\
\hline
\end{tabular}




\begin{tabular}{|c|c|}
\hline IOC & Indian Ocean Commission \\
\hline MAMWE & Water and Electricity Production and Distribution Company \\
\hline MDG & Millennium Development Goals \\
\hline ME & Monitoring and Evaluation \\
\hline MECK & Savings and Loan Associations ya Komor \\
\hline MICS & Multiple Indicators Cluster Survey \\
\hline MTBF & Medium Term Budget Framework \\
\hline MTEF & Medium Term Expenditure Framework \\
\hline PAP & Pluriannual Action Plan \\
\hline PASCO & Comorian Health Sector Support Project \\
\hline PCD & Decentralized Cooperation Program \\
\hline PDLC & Comorian Local Development Program \\
\hline PIN & National Indicative program \\
\hline PIP & Public Investment Program \\
\hline PIR & Regional Indicative Program \\
\hline PNDHD & National Program for Sustainable Human Development \\
\hline PNEEG & National Gender Equality and Equity Policy \\
\hline PNLP & National Anti-Malaria Program \\
\hline PNRH & National Human Resources Program \\
\hline PRCI & Institutional Capacity Building Project \\
\hline PREDIVAC & Project to Strengthen and Diversify the Agricultural Sector in the Comoros \\
\hline PRGF & Poverty Reduction and Growth Facility \\
\hline PRGS & Poverty Reduction and Growth Strategy \\
\hline PRGSP & Poverty Reduction and Growth Strategy Paper \\
\hline PTF & Technical and Financial Partner \\
\hline PU & Single Program \\
\hline RGPH & General Population and Housing Census \\
\hline RMP & Mid-Project Review \\
\hline SADC & Southern Africa Development Community \\
\hline $\mathrm{SCH}$ & Comoros Hydrocarbon Company \\
\hline SIG & Geographic Information System \\
\hline SME/SMI & Small and Medium-Sized Enterprises/Small and Medium-Sized Industries \\
\hline SNPSF & National Postal and Financial Services Company \\
\hline SNU & United Nations System \\
\hline STP & Permanent Technical Secretariat \\
\hline TAP & Automatic Payment Machine \\
\hline TIC & Information and Communication Technology \\
\hline TOFE & Government flow of funds table \\
\hline $\mathrm{UC}$ & Unit of Account (African Development Bank) \\
\hline UNCDF & United Nations Capital Development Fund \\
\hline UNCTAD & United Nations Conference on Trade and Development \\
\hline UNDAF & United Nations Development Assistance Framework \\
\hline UNFPA & United Nations Fund for Population Activities \\
\hline UNICEF & United Nations Children's Fund \\
\hline UNIFEM & United Nations Development Fund for Women \\
\hline US & United States of America \\
\hline USD & United States Dollar \\
\hline WB & World Bank \\
\hline WHO & World Health Organization \\
\hline
\end{tabular}




\section{Executive summary}

The Union of Comoros is a less developed country, a member of the sub-category of vulnerable small island states. Since its independence in 1975, it has been deeply affected by political and institutional crises, sources of prolonged instability. Resolution of the separatist crisis on the island of Anjouan and subsequent national consolidation and reconciliation have constituted a historic turning point for the Union.

The context for implementing the PRGSP bears the stamp of the third democratic alternation of power within the new institutional framework of the Union of Comoros established in 2001. The new president of the Union of Comoros, Dr. Ikililou Dhoinine, was elected in December of 2010 and took office on May 26, 2011, after the assumption of their offices by the governors of the islands on May 23, 2011.

The government began a wide-ranging program of structural reforms centered on a reference program with the IMF, leading to generally good macroeconomic performance. In a context marked by a lowering of political tensions, foreign assistance has remained substantial and domestic lending relatively strong. The budget year balance recorded no unpaid wages due.

Economic activity in the Union of Comoros has proceeded in a rather favorable context, despite a difficult international environment characterized by the public debt crisis. In 2011 the real GDP growth rate was 2.6 percent, compared to 2.2 percent in 2010, despite an annual average inflation rate estimated at 1.8 percent in 2011, and the increase in the prices of energy products, along with a rise in the value of the dollar compared to the euro on the international market.

The external debt of the Comoros remains unsustainable, representing as it does 343 percent of exports. The government is making efforts to speed up the implementation of triggers, in order to reach the completion point of the HIPC initiative and obtain access to an appropriate reduction in its debt burden.

Our country's external trade exhibits an increase in the flow of exchanges with a degree of openness of the economy of 52 percent in 2011, compared to 47.8 percent in 2010, and a rate of coverage of imports by exports of 9.1 percent, compared to 8.9 percent in 2010 . The balance of payments therefore shows a deterioration of the balance of current transactions, totaling CF 29.1 billion (14.1 percent of GDP) in 2011.

In 2011, the money supply stood at CF 64.7 billion, compared to CF 57.6 billion in 2010 . Also in 2011, the required reserve ratio was brought down to 25 percent. In the same year, savings improved, reaching a total of CF 26.5 billion, compared to CF 25.7 billion in 2010. Domestic lending grew by 4.3 percent, bringing the total to CF 45.5 billion in 2011 after a total of 43.7 billion in 2010 .

Studies undertaken in 2003 show that one person out of two is poor in the Union of Comoros. Approximately 369 individuals out of 1000 are living below the threshold of poverty, including more than 78.8 percent in rural areas. The incidence of household poverty is estimated at 36.9 percent, which means that one individual out of two 
(44.8 percent) would be classified as poor according to the monetary poverty index. Three socio-economic groups account for nearly two-thirds of poverty: farm households (30.2 percent), families of unprotected wage earners (15.8 percent), and households with an unemployed individual as head (19.6 percent).

In sum, according to the year 2003 studies, all indicators of inequality point to a net growth in disparities. The Gini inequality index has increased by 25.7 percent (from 0.443 to 0.557 ). As for households, the impact of redistributed income is greater on Grand Comoro than on the other two islands. Transfer income from traditional and customary sources and income from citizens residing abroad tend to mitigate the depth of poverty. However, that state of affairs further underscores the vulnerability of populations because of the random character of these sources of income. The vulnerability of households is slightly more widespread than poverty itself. For instance, the ratio of persons exposed to short-term poverty is markedly greater that the incidence of poverty.

In the absence of recent data, the positive trend in certain priority indicators favoring poor and vulnerable groups would suggest that the incidence of poverty has decreased in 2011.

Implementation of the PRGS priority action plan in 2011 has had generally positive effects in the whole range of sectors.

Satisfactory results were recorded in the area of public finance, the result of government efforts undertaken in the sector. Thanks to an improvement in government receipts totaling 16.1 percent of GDP (including 3 percent attributable to exceptional receipts from the economic citizenship funds), in 2011 the primary balance posted a surplus equivalent to 1.6 percent of GDP, compared to the deficit of 1.6 percent of GDP for fiscal 2010. The wage bill was reduced to a level that is more compatible with the government's ability to mobilize domestic resources (8.5 percent of GDP) in the wake of the cancelled wage increase agreed to in 2010.

Efforts to mobilize domestic resources and strengthen control over expenditures undertaken in 2010 generated additional gains in fiscal consolidation. The base budgetary balance also improved (1.1 percent of GDP in 2011, compared to a deficit of 2.2 percent in 2010), as did the public debt ratio, from 65.4 percent in 2010 to 59.9 percent in 2011 .

The external current account deficit for 2011 is estimated at nearly 9.5 percent of GDP (versus 7 percent of GDP in 2010), linked to an increase in world prices of food and petroleum products, the resumption of imports linked to direct foreign investments, and the slight decline in financial flows from budgeted supports. Gross transfers by Comorians residing abroad rose modestly.

The external debt of the Comoros remains unsustainable. It represents 343 percent of exports and forces the government to speed up the implementation of triggers in order to reach the completion point of the HIPC initiative and obtain a sizeable alleviation of the country's debt burden.

The entire range of programmed structural reforms scheduled has been delayed - for example, the implementation of new civil service internal frameworks and finalization of the census of civil servants. 
As for trade, 2011 exports increased in value to CF 8.9 billion, compared to the 2010 figure of CF 7.7 billion, thanks to sustained external demand and good export prices for cloves. In the same time frame, the value of imports rose to CF 97.9 billion in 2011, up 13 percent compared to 2010 . The degree of openness of the economy stands at 52.0 percent and the rate of coverage of imports by exports stands at 9.1 percent as of 2011.

The energy sector continues to be affected by difficulties encountered by the national company in providing regular distribution of electrical power. Massive fraud results in commercial losses estimated at 30 percent. The electrification rate is estimated at 45 percent, i.e., below the 50 percent projected in 2011, and this despite efforts made to extend hookups to the network, and in particular the situation on the island of Mohéli, with a rate of 70 percent.

The increase in prices of petroleum products on the international market has had no repercussion on consumer prices. The cost per kilowatt hour has remained unchanged at CF 132. This sector subsidy policy reflects the determination on the part of the authorities to protect vulnerable members of society.

In the area of infrastructure, the government had set as a year 2011 priority the repair of highly damaged roads. A sweeping program was undertaken based on economic citizenship to repair $41 \mathrm{~km}$, including $17 \mathrm{~km}$ on Ngazidja, $17 \mathrm{~km}$ on Ndzouani, and $6.5 \mathrm{~km}$ on Mwali. Repairs cover the airport corridor Ouani-Mutsamudu as well access to the basin on the island of Anjouan and, on Mohéli, repair of the Djoiezi-Fomboni corridor. On Ngazidja, the corridor Coulée de laves-Bahani-Itsandra is to be repaired, with work to begin in 2012, and on Mwali, the Djoiezi-Fomboni corridor. In Moroni, rehabilitation and rebuilding of $3.5 \mathrm{~km}$ of urban roadways is to be undertaken. Road maintenance of the Moroni-Hahaya corridor was financed by FER funds. The AFD financed asphalt paving of the Hajoho-Jimilime road.

We should also mention the start of PADST activities with establishment of technical assistance (20 percent of the startup advance was already released).

Nevertheless, it must be emphasized that completed work has not attained the year's targeted objectives. In fact, beyond the problems of slow government contracting procedures, we find an enormous deficiency of human and financial resources.

In the area of telecommunications, the household subscription rate rose to 59 percent in 2011 compared to 54 percent in 2010, the slight increase attributable to network improvements made in 2010. In addition, the ADSL product was connected to the network. It must nevertheless be noted that the sector is closed to competition and offers the consumers no alternatives for acquiring better services at competitive prices.

As regards the strengthening of the rule of law, administrative buildings have been constructed and/or rehabilitated in the course of the year 2011. We note construction/rehabilitation of rooms within various jurisdictions (SNU), construction of council headquarters on the islands of Mohéli and Anjouan (PCD/UE), construction of the weather bureau (government), and construction of the office of tourism (China). Public housing has also been built within the framework of experimentation with clay bricks. Comoros Telecoms has built commercial agencies in certain localities with its own 
financing. The most significant completed building project was construction of the courthouse in Mwali, a project long-awaited by the local population, in light of the dilapidated condition of the previous cramped courthouse.

No significant progress has been seen in water and sanitation services, in particular access to sources of drinking water. The 11 percent rate of access to potable water has only been observed in the case of Moroni. Despite new construction of water conveyance facilities and drilling wells for community systems, the rate of access has not shown a net improvement because of a lack of water analysis and treatment systems in rural areas.

The number of households benefiting from a sanitation program stands at 300 . This figure exceeds the target proposed for 2011. Sanitation efforts undertaken with the support of the PAEPA project of ADB continues to lead in these progressive efforts.

The built water network has reached 23 kilometers, exceeding projections by one kilometer in 2011. This performance resulted from implementation of the water conveyance program for rural areas financed by AFD, which has also been active in Djando on Mohéli and Domoni and Sima on Anjouan.

The government has initiated substantial reforms aimed at improving the business climate in the private sector. The secretariat for this huge project is provided by the National Agency for Promotion of Investments. It has benefited from the manifold support of the PTFs, and in particular the SFI. The reforms have concerned the areas of creation of enterprises, transfers of property, accessing loans, and execution of contracts.

With reference to the World Bank Doing Business Report, our country has focused its attention on 4 indicators from among those regarding ratings. In 2011, the Comoros were rated number 159 (156 if electricity is included). In access to credit, the Comoros have moved up from the $170^{\text {th }}$ position to rank number 150 as a result of the OHADA amendment to the article on credit.

The 107 new businesses created are testimony to the results of these efforts.

AMIE has supported 32 SMEs for a total of CF 22,909,000 using small lines of credit opened for promoters unable to acquire a guarantee fund.

The amount of bank lending rose from CF 43.704 billion in 2010 (including CF 35.304 billion for the private sector) to CF 45.852 billion in 2011, including CF 38.275 billion for the private sector. Nevertheless, the volume of long-term credits continues to be small, thereby limiting business investment capacity.

Agricultural land tenure continues to be problematic and constitutes a real obstacle, particularly as regards the status of the user of the land. For 2011, the land registry agencies have received no requests for registering farm parcels, in flat contradiction to the 25 percent target set in 2011, and this despite financial resources already mobilized from partners, including FIDA (PNDHD) designed to support security of land holdings, under the subtitle protection and development of vulnerable sites.

The growth rate of foodstuffs production exceeded the target set for 2011, despite immobility in the rate of agricultural investment. This performance was due to support for 
farming inputs and the multiplication of food seeds provided by our partners in development, in particular the IDB, PNDHD and UN System. Construction by AFD of the roadway Hajoho-Jimiliméune, a region with strong agricultural potential, had a positive effect on that indicator. In addition, the development of irrigation systems for agricultural areas in Pomoni (on Anjouan), promotion and development of small-scale processing and preserving facilities for short-term preservation of perishable products (UN System), and the creation of a laboratory for analysis of food products, all contributed to the performance of the sector.

In the livestock segment, the rate of vaccination coverage for ruminants made a gain of 18 percent, below the 40 percent rate targeted, and this despite the support from FIDA and the NGOs Activa/APSA and ACDE. The vaccination campaign concerned anthrax, Rift Valley fever, and theileriosis. The rate was satisfactory for poultry: it rose from 25 percent in 2010 to 87.06 percent in 2011. The exceptional campaign undertaken by VACNADA (EU) made a substantial contribution to that performance, with the campaign including local poultry as well. The mortality rate dropped to 20 percent in 2011 , from 80 percent recorded in 2010. Nevertheless, the need for protein covered by the campaign represents only 30 percent of local consumption, thereby justifying the massive imports of uncooked poultry, meat products and bovids.

The outlook is favorable for milk production, thanks to a widespread insemination campaign to introduce cross-bred species of cows (297 cows inseminated out of the target figure of 600).

The growth rate for fishing stayed at 3 percent between 2010 and 2011. Climate change perturbations contributed to that state of affairs, with fishing catches dispersed outside the usual zones. It is urgent that we envisage modernization of the sector by introducing new fishing techniques and fleets able to navigate on the high seas in order to have an impact on the rate of production. In that respect, the involvement of Qatar, investing in the sector for the external market, will have a substantial effect on production, thereby justifying our exceeding the target set for boosting the investment rate.

Tourism is one of the priority sectors decided upon by the authorities for participation in economic recovery. In 2011, the sector's growth rate was estimated at 3.30 percent, compared to 23.04 percent in 2010, despite the increase in hosting capacity. Conditions in the transportation sector account in a major way for this underperformance. The high cost of Comoros as a destination, combined with the lack, irregularity, and uncertainty of direct flights to major touristic markets, together with poor interconnections of flights, have devastated the tourism industry. Construction of a tourism office by China will no doubt contribute to achievement of the goals set. The sector should also make significant progress with the construction and operations of the new tourism welcome center in the port of Moroni.

Several accomplishments can be recorded in the area of governance and social cohesion. These include completion of CAP studies on: prejudice, discrimination, citizenship, female and youth expectations from social cohesion, establishment of 16 peace committees, organization of reconciliation between ex-FGAs and their victims, introducing biometrics into the electoral rolls, and establishment of the national commission on the fight against corruption. 
A genuine impact on the effectiveness of our administration can be expected from the activities of the AGBE/BM project on the census of civil servants, widespread use of the updated integrated system for managing employees of all three islands (ISE), as well as reform of financial controls and approval of internal frameworks.

The judicial system will see the creation of jurisdictions complementing courts of first instance exceeding the targets set in 2011, in addition to the 32 cadis and the establishment of the Supreme Court, all of which will make an impact on the time required for processing judicial cases. The new courthouse in Mwali, together with hiring of staff for the island will have an impact on the time required for processing cases, an area in which the island used to be deficient.

Improving the health of the population constitutes a major challenge for the authorities. The incidence of malaria discovered in doctor's office visits has dropped from 50 percent in 2004 to 36 percent in 2011. It should be emphasized that although sickness remains at a high level, mortality has been reduced markedly thanks to available, free treatment for cases of simple malaria, and the mass treatment campaign on Mohéli between 2008 and 2010.

The fight against avoidable illnesses through vaccination shows improved vaccination coverage per antigen. In 2011, the vaccination coverage for the various antigens was, respectively, 88 percent for BCG, 92.1 for DTC/Hep/Hib 1, 86.7 percent for DTC/Heb/Hib 3, 78 percent for scarlet fever, and 22.8 percent for VAT2+. This improvement resulted from the installation of new instruments and equipment; support for training; validation of PPAC; installation of vaccines; and implementation of management tools for vaccination services, with the support of GAVI, UNICEF, JICA and WHO. These efforts have had a positive effect on certain indicators related to the health of mothers and children. The available information shows a clear improvement in achieving MDG 4 related to reducing the rate of mortality of children under 5 years of age.

In the area of education, the objective was to develop education and professional training with a view to improving human capital. The rate of enrollment in technical and professional education rose from 3 percent in 2010 to 8 percent in 2011, thanks to the multiplication of centers for technical education and professional training; however, the rate is still significantly lower than the targeted figure of 15 percent for 2011 . At the University of the Comoros there has been a significant increase in the rate of admissions of new secondary school graduates to the first year of studies. This rate increased from 50 percent in 2010 to 60 percent in 2011. Despite the increase in the rate of admissions, the very young Comorian university was unable to reach the target figure of 77 percent set for 2011 because of its limited acceptance capacity, resulting in a massive departure of new secondary school graduates to foreign universities.

Preschool enrollments are estimated at 16 percent for 2011, a significant increase of 10.9 percentage points over the period of a single year (the rate was 5.1 percent in 2010). Despite this progress, the Comoros have been unable to reach the targeted figure of 35 percent. Among the causes of this underperformance were lack of financial resources and classrooms in insufficient numbers and in dilapidated condition.

In the area of successful completion of primary school instruction, the Comoros progressed by five percentage points in 2011 (62 percent) compared to 2010 (57 percent). 
As a result, the number of pupils not successfully completing primary school stood at 38 percent in 2011, or 28,000 children in the cohort of ages 6 to 11 years.

The net rate of admissions to primary schools practically doubled between 2010 and 2011 , from 34.6 percent to 60 percent, for a remarkable increase of 25.4 percent, the result in particular of improved access to basic education.

Of the HIPC indicators, 2 out of 4 were achieved. Future efforts need to be made to provide school books and latrines.

In the sector of the environment the PRGSP aims at promoting the sustainability of the environment and national security. The completion of 5 fauna and flora inventories in the priority zones for conservation of biodiversity exceeds the forecasts drawn up for 2011 . This success benefited from the support of the OCB project, the ECDD project, and the National Forestry Inventory (IFN). In addition, 1,531 persons were trained in various areas with a view to developing and strengthening their capacities for managing AGRs, with linkage to the goals of preserving and making sustainable use of natural resources, while 965 persons were trained in adopting methods and systems for increasing productivity of traditional agroforestry and techniques of integrated biological pest control and agrobiology. In 2011, it was noted that 20 percent of land making up the surface of the Comoros was adaptable to the system of agro-biodiversity. The annual target of 30 percent could not be reached because of inadequate financial resources.

In terms of public safety, 30 percent of government institutions have mastered the actions that need to be taken in the face of a catastrophe. In order to reach this outcome, widespread campaigns promoting awareness on the part of elected officials, prefects, mayors and primary school teachers have been undertaken. Much effort remains to be deployed within the framework of mobilization, taking priority geographic zones into account. A study of the vulnerability to the main climatic and natural uncertainties resulted in the preparation of three risk vulnerability maps (volcanos, floods, and landslides) as part of the Acclimate project.

As far as resource mobilization is concerned, out of CF 92,977 million programmed, CF 57,089 million have been mobilized, for a rate of 62 percent. Credit for this performance is due to the sectors of water and sanitation (206 percent), governance (113 percent), and energy (98.8 percent), which made very substantial contributions. The social sectors of health and education recorded respective mobilization rates of 39.5 percent and 34 percent.

Finally, the report noted slight capacity for generating data for follow-up of indicators, as well as the limited capacity of local managers for generating the technical documentation required by resource mobilization. 


\section{General introduction}

In August 2009, the Union of Comoros adopted a Poverty Reduction and Growth Strategy Paper, the successor to the interim version of 2005. The PRGSP was drawn up using the participatory and inclusive approach engaging all parties concerned with development, with the support of development partners. This approach enabled a broad consensus among all the participants in development, making the PRGSP the sole reference framework for programming and budgeting of government strategic actions, as well as the dialogue with the technical and financial partners. The strategic framework for fighting poverty integrates the imperatives of post-conflict recovery and achievement of the MDGs. The essential objectives aimed at within this framework are: consolidation of the peace and strengthening of good governance; creation of wealth and generation of substantial revenues within the framework of pro-poor growth; and broadening of access to basic social services. This entire project takes the form of an action plan taking into account cross-disciplinary issues in human rights, gender, improved production and access to statistical data; development of and access to ICTs; trade policy as a component of development strategy — with the MDGs acting as a unifying framework.

In the course of the Doha Conference, held in the month of March 2010 in the capital of Qatar at the initiative of the government of the Union of Comoros, under the auspices of the government of His Highness, the Emir of Qatar, the League of Arab States, the Islamic Development Bank, and the United Nations, the mobilization of resources was undertaken within the framework of the priorities contained in the PRGSP. The government of the Union of Comoros obtained overall financial assistance totaling USD 540 million. Continuing this process of resource mobilization to finance the PRGSP, the government of the Union of Comoros established a framework for following up the Doha Conference, with implementation taking the form of a series of missions and consultations between the Comoros and Qatar and formalization of participation frameworks for the partners involved.

Formalization of the institutional framework for implementation, monitoring and evaluation was successfully completed and the associated regulatory rules were adopted. The remaining challenge is to operate the framework effectively, which should make for more thorough ownership and approval by the national leadership, as well as a more operational involvement of all the national participants in the implementation of the PRGSP.

Following the current exercise, bearing on assessment of the progress of the program at the end of its second year of implementation, in order to measure the progress made, it is essential to proceed to an adequate adjustment so as to improve the expected results, performance, and national ability to absorb the resources mobilized and placed at the disposal of Comoros. In addition, we must draw up - and seek adoption by the relevant bodies - of a road map showing the major actions to be undertaken by the national partner in order to achieve these goals.

The present report on implementation of the PRGSP pursues a twofold objective, namely:

- to sum up the execution of the PRGSP in 2011; 
- to identify the constraints and difficulties encountered during the implementation period, as well as the opportunities made available to Comoros to pursue in satisfactory fashion the deployment of actions arising from the PRGSP.

As regards methodology, the present report proceeds as follows:

- design, validate, and adopt the tools needed to gather the principal types of data related to execution of the program and projects at the sector level;

- launch the process of sectoral reporting, based first of all on the Sectoral Focal Points of the Office of the Commissioner General for Planning (CGP), and secondly on their equivalents at the operational level, i.e., the sectoral ministerial departments, and in particular the Technical Working Groups (GTS);

- organize sectoral workshops to validate sectoral reports using members of the Sectoral Technical Groups;

- draw up a summary report of the second year of implementation of the PRGSP by consolidating the validated sectoral reports;

- present the summary report to the national workshop on annual implementation review;

- the national expert charged with drawing up the report incorporates commentaries and contributions arising at the workshop and files the final report within about 10 days.

The present report consists of an Introduction six Parts, a Conclusion, and Recommendations:

- Part I analyzes the macroeconomic framework for implementing the PRGSP.

- Part II analyzes the implementation of priority actions in 2011 and takes stock of the HIPC triggers.

- Part III assesses capacities to implement, monitor, and evaluate.

- Part IV presents the conclusions and recommendations.

- Part V contains the annexes and the list of the major report tables.

This report on the second year of implementation of the PRGSP was not able to take into account all the indicators it was supposed to use as references, for the following reasons:

- resources not set aside for financing inquiries aimed at collecting data for the indicators and updating them; 
- constraints (of what type?) encountered by the institutional body regarding coordination, monitoring, and evaluation;

- inadequacies of the National Statistics System, poorly endowed with human and especially financial resources;

- lack of resources for implementing certain priority actions.

In drawing up this second report on implementation of the PRGSP, despite numerous constraints weighing on the effort, the government of the Union of Comoros gives proof of its commitment to make of the PRGSP a tool for economic and social programming and development, and for evaluating its implementation on a regular basis using its institutional framework of monitoring and evaluation. The government is persuaded that the PRGSP constitutes a framework for effectively mobilizing external resources, and especially for strengthening coordination of development assistance based on national priorities and the government's leadership. It is also counting on the need to adopt implementation that is at once inclusive and participatory, with rigorous monitoring and evaluation of actions, so as to measure the impact of actions undertaken and results achieved in the course of the joint mission with its development partners.

By undertaking this exercise related to the second consecutive year, and by presenting a summing up in the form of a comparison between objectives, resources mobilized, achievements and initial results, the government wished to appeal to its development partners and its donors, so as to draw out mutually beneficial lessons from this second year of PRGSP implementation, in order to proceed, where applicable, to making the needed adjustments of strategies and programs for the subsequent stages of the process.

\section{MACROECONOMIC FRAMEWORK AND SITUATION OF POVERTY}

\section{Macroeconomic situation}

Economic activity of the Union of Comoros has been undertaken in a rather favorable context, in spite of a difficult international environment marked by the government debt crisis. This state of affairs benefited from sustained domestic demand on the rise, and in particular incoming funds from Comorians living abroad, as well as an increase in lending to the private sector. Real GDP grew at the rate of 2.6 percent in 2011, compared to 2.2 percent in 2010. That growth was sustained by a healthy agricultural sector and transfers from Comorian expatriates.

The average annual inflation rate is estimated at 1.8 percent for 2011 , compared to 3.8 in 2010 , in spite of the rise in energy products and a hike in the rate of the dollar against the euro on the international market. 


\section{Change in the real sector}

The volume growth rate of GDP in 2011 was sustained by an increase in production in the areas of agriculture, livestock, and fishing, which posted an increase in its contribution to GDP of 2.1 percent. The secondary sector contributed 0.4 percentage points in 2011 , versus 1.7 points in 2010. The tertiary sector posted an underperformance following an increase of 10 percentage points of its contribution from 2009 to 2010 . This underperformance resulted from the weak energy, transportation and telecommunications sector.

External trade of the Union of Comoros saw an increase in the flow of exchanges, with a degree of openness of the economy standing at 52 percent in 2011, compared to 47.8 percent in 2010, and a rate of coverage of imports by exports of 9.1 percent in 2011, versus 8.9 percent in 2010, which increase was due specifically to the buoyant price for cloves.

\section{Public finance}

The Union of Comoros is posting improved major budget balances, including a primary balance that improved by CF 3.4 billion in 2011, following a deficit of CF 3.3 billion in 2010. This is explained by an increase in domestic receipts and in particular the 75.4 percent increase in nontax receipts in 2011 when compared to 2010.

Customs duties based on improved value of imports generated an increase of 4.8 percent of tax receipts compared to 2010, reaching a level of CF 23.5 billion in 2011, compared to CF 22.4 billion in 2010, an improvement resulting from the reintroduction of ad valorem taxation and an increase in the volume and prices of exports.

External accounts exhibited a deterioration of the deficit of the current transactions balance, standing at CF 29.1 billion in 2011, compared to CF 19.4 billion in 2010, or 14.1 percent of GDP versus 9.8 percent, respectively. The balance of the trade deficit stands at CF 68.1 billion as of 2011, versus CF 60.3 billion in 2010.

Efforts to mobilize internal resources and strengthen the grip on expenditures undertaken in 2010 generated additional gains in terms of budgetary stabilization. With credit going to undertaking more sustained mobilization efforts at year's end, the share of government receipts in GDP reached 16.1 percent, including 3 percent due to exceptional economic citizenship receipts. This figure exceeds significantly the revised forecast of 13.1 percent formulated in 2010, together with an expected attainment of 14.3 percent of GDP for the same year. Total net expenditures and lending grew by 21.5 percent, representing 26.4 percent of GDP in 2011, versus 22.7 percent in 2010. Current primary expenditures rose by 6.7 percent, including control over the wage bill (negative 0.5 percent) and interest paid on the debt (negative 14.9 percent).

The base budgetary balance improved meanwhile (1.1 percent of GDP in 2011, compared with a deficit of 2.2 percent in 2010). Public indebtedness also improved, with a rate of 59.9 percent in 2011, versus 65.4 percent in 2010.

The foreign debt of Comoros remains unsustainable, representing 343 percent of exports. The government is attempting to speed up the implementation of the triggers for reaching 
the completion point of the HIPC Initiative and obtain relief of its debt burden.

Specifically, the completion criterion at end-December 2010 for net reduction of domestic payment arrears fell short by 0.5 percent of GDP. Faced with an unsustainable wage bill, the government suspended payment of all wages, in its determination to renegotiate the wage increase granted in October of 2010.

The completion criterion for net domestic credit to the state was exceeded slightly, by 0.2 percent of GDP, in the wake of a delay in implementing scheduled structural reforms such as the internal frameworks, scheduled for July 2011.

\section{Balance of payments and monetary survey}

The balance of payments exhibits a deterioration of the current account balance standing at CF 29.1 billion (14.1 percent of GDP) in 2011, compared to CF 19.4 billion in 2010. Customs statistics show that the trade deficit at FOB prices widened by CF 7.8 billion, standing at CF 68.1 billion in 2011, versus CF 60.3 billion in 2010. This situation is explained by the brisk pace of imports, which did not however slow the growth of exports. Imports increased in CAF value by CF 11.4 billion, a rise of 13 percent, explained by the greater cost of oil, while exports grew by CF 1.2 billion (16 percent) because of the buoyant price for cloves.

The rise in the services deficit is explained by the significant weight of insurance and freight costs and the drop in the figure for travel.

The income account improved, as a result of the drop in outgoing external debt payments.

In the course of the first half of 2010, the monetary survey saw average growth of 2 percent, establishing money in circulation at CF 64.7 billion, versus CF 57.6 billion in 2009.

The attitude toward government indebtedness to the banking system remains cautious, to allow sufficient expansion of credit to the private sector. The ratio of required reserves remains the main instrument for regulating liquidity. It was brought down to 25 percent in 2011 , in response to a gradual weakening of demand for credit in a context of persistent excess liquidity in the banking system.

\section{Money, credit and the financial system}

Monetary expansion continued in 2011, with growth of 9.6 percent, on the heels of 19.4 percent growth in 2010. This growth was mainly attributable to the increase in net external assets (16.1 percent), with domestic credit posting growth of 4.2 percent after a rise of 17.6 percent in 2010 . The external coverage rate of the currency stood at 70.9 percent in 2011, compared to 66.9 percent in 2010.

Savings improved, climbing to a level of CF 26.5 billion in 2011, compared to CF 25.7 billion in 2010. The opening of the financial sector enabled creation of new financial products that incentivized domestic savings. 
Credits to the economy constituted the engine of growth, totaling CF 39.8 billion. This lending to private enterprises and households was chiefly in the form of short-term lending (more than 60 percent of the total), aimed at trade.

As for domestic lending, it grew by 4.3 percent, reaching CF 45.5 billion in 2011, versus CF 43.7 billion in 2010 .

\section{Poverty and vulnerability}

\section{Situation of poverty in the Comoros}

The execution of a program to fight poverty requires availability of information able to guide economic policy and specific actions designed for the program objectives. The year 2004 inquiry into the perceptions of poverty showed that many households had trouble satisfying their food needs in satisfactory fashion. The main aspects for improving peoples' well-being according to their own perceptions, are: access to quality health care; access to drinking water in sufficient quantity and of adequate quality; education, and in particular, job training; housing; employment; credit; electrical power, etc.

\section{Studies undertaken in 2003 show that one person out of every two is poor. Approximately 369 individuals out of 1000 live below the threshold of poverty.}

Poverty is especially predominant in rural areas, where the incidence of poverty is 39.1 percent for Ngazidja, 43.5 percent for Ndzouani, and 38.3 percent for Mwali. Studies conducted by the Comprehensive Household Survey (EIM) showed that the rural zones contributed 78.8 percent of the cases of household poverty in Comoros in 2004.

In cities it has been found that one individual out of every four lives below the poverty threshold, or 25 percent of the urban population. This low rate must not conceal a sizeable extension of poverty. In the city of Moroni, the poverty rate has climbed from 14.9 percent in 1995 to 21.02 percent in 2004, an increase of 20 percent. In recent years the phenomenon of rural exodus is observed in a corresponding swelling of urban centers. Areas previously rural in character have become suburbs exhibiting a strong demographic explosion.

\section{Incidence of poverty}

For the country as a whole, the incidence of poverty at the level of households was estimated at 36.9 percent in 2004 . On an individual basis, this translates as one individual out of two (44.8 percent) able to be classified as poor according to the index of monetary poverty.

The results of the EIM inquiry allow us to identify four socio-economic categories that are relatively distinct from the point of view of the incidence of poverty: (i) households whose head is a protected wage earner (incidence of poverty: 25.5 percent); (ii) households headed by an unprotected wage earner (incidence of poverty: between 30 percent and 35 percent); (iii) subgroups whose head is a foodstuffs farmer, a farmer renting land, an unemployed person living outside the workforce (incidence of poverty: between 38 percent and 39 percent); (iv) households headed by a micro-entrepreneur, a cattleman 
or a fisherman (incidence of poverty: between 46 percent and 54 percent). We note that three socio-economic groups account for nearly two-thirds of national poverty: farming households (30.2 percent), households headed by an unprotected wage earner (15.8 percent), and households where the head of household is not a participant in the workforce (19.6 percent).

Data on the economic environment support the hypothesis of an improved socio-economic situation and an increase in poverty, with the volume of investments making an impact on employment.

\section{Poverty and distribution of incomes}

Over the period 1995-2004 at the national level, the inequality of per capita expenditures widened considerably. All the inequality indicators show a net increase in disparities. The Gini index rose by 25.7 percent (from 0.443 to 0.557 ). At the level of households, we see an increased gulf in inequalities attributable to income elasticity compared to expenditures. The stock of income remained unchanged while real per capita income fell on the order of 1 percent since 2008, at a time when expenses rose because of imported inflation affecting consumer goods.

Growth during the period was weak just offsetting the rate of population growth. The impact of redistributed income was greater on Grande Comoro than on the other two islands. Transfer income emanating from traditions and customs as well as from Comorians living abroad go a long way toward mitigating poverty. Nevertheless, this state of affairs merely serves to underscore vulnerability, given the random nature of this income.

The breakdown of sources of inequality throws into relief the role of household demographics (especially the number of children aged 5-14 years), as well as the level of instruction of the head of the household, the number of employed persons per household, and the geographic location of the household. We also note that the existence of external transfers has the effect of boosting the inequality of expenditures, especially on Ngazidja. However, the available data do not permit verification of the change in the situation in terms of inequality up to the year 2011. Weak growth added to high inflation reveals an intensification of inequalities accounting for an increase in deep poverty over the course of recent years in Comoros.

\section{Vulnerability}

Vulnerable households are more numerous than poor ones. Persistently poor households, poor households in transition, and non-poor, precarious and vulnerable households continue to be very vulnerable. While 36.8 percent of households are poor, 47 percent are very vulnerable. The number of persons exposed to the risk of poverty in the short term is markedly greater than the incidence of poverty itself. With an average ratio of vulnerability of 0.405 versus a ratio of poverty of $0.37,25$ percent of non-poor but vulnerable and precarious families have an 80 percent chance of dropping back into poverty in the short term. 


\section{Poverty and economic growth}

The profile of poverty shows the urgency of making a fresh launch of the growth process and the need to fight with determination against the causes of poverty in Comoros. The EIM results show the importance of the private sector to this recovery, in particular in the agro-food areas, in order to ensure strong economic growth and reduce the incidence of poverty in significant fashion. The dynamics of the process must also be extended to the economic operators of the other profitable sectors (tourism, trade, public works and building), which are able to bring the required investments to the recovery of growth and create jobs and reduce the poverty in which numerous Comorian families are now living, according to the study of sources of growth in the Union of Comoros financed by the African Development Bank. On the other hand, growth alone is not sufficient to guarantee a significant reduction in poverty if inequalities become ever more acute, access to education and healthcare does not improve, and the environment degrades. The government has therefore made access to education, to quality healthcare (especially reproductive health) and preservation of the environment priorities able to improve the living conditions of Comorians within the framework of the Poverty Reduction and Growth Strategy.

\section{IMPLEMENTATION OF THE PRIORITY ACTION PLAN IN 2011 AND HIPC TRIGGERS}

\section{Core strategy 1: stabilize the economy and lay the groundwork for strong growth based on equity}

This core strategy concerns: the manner in which major public finance reforms are undertaken, as well as the recasting of the administration; adoption of an incentivizing trade policy; integration of Comoros into the regional and world economies; implementation of measures aimed at increasing competitiveness of the Comorian economy, and in particular in the profitable sectors of foodstuffs, agriculture and tourism; accomplishment of reforms and investments with a view to ensuring reliable energy supplies at a reasonable cost, and the construction and improvement of basic economic infrastructures (roads, ports, airports, telecommunications) designed to sustain foreign trade and enable Comorian economic operators to harness opportunities arising in the domestic market. Finally, this core strategy bears on improving access to drinking water and sanitation services.

\section{a) Public finance}

The PRGSP has set itself the objective of improving the operations of government and public finance. Implementation of sectoral programs and projects in 2011 has featured the following:

- passage of Law No. 11-007B/AU dated May 3, 2011 related to the General Tax Code; 
- passage of Law No. 11-027/AU dated December 29, 2011 related to government procurement contracting and delegation of government services;

- ad valorem taxation in customs replacing presumptive taxation.

\section{Breakdown of priority indicators}

\begin{tabular}{|c|c|c|c|}
\hline Priority indicators & $\begin{array}{l}2010 \text { reference } \\
\text { value }\end{array}$ & 2011 target & 2011 completions \\
\hline Total indebtedness & CF 99.3 billion & ND & CF 88.8 billion \\
\hline Debt service & CF 2.6 billion & ND & CF 2.7 billion \\
\hline GDP growth rate & 1.6 percent & ND & 2.6 percent \\
\hline Inflation rate & 3.8 percent & ND & 1.6 percent \\
\hline $\begin{array}{l}\text { Primary balance as } \\
\text { percentage of GDP }\end{array}$ & -1.6 percent & -1 percent & 1.6 percent \\
\hline Tax revenues & CF 22.4 billion & 5 percent & CF 23.5 billion $(4.80 \%)$ \\
\hline Nontax revenues & CF 6.4 billion & 3 percent & CF 11.2 billion $(75.5 \%)$ \\
\hline Gross investment rate & 16 percent & $\mathrm{ND}$ & 17 percent \\
\hline $\begin{array}{l}\text { Share of education in } \\
\text { budget }\end{array}$ & CF 12.775 billion & 8 percent & CF 15.4 billion (6.2\%) \\
\hline $\begin{array}{l}\text { Share of health care in } \\
\text { budget }\end{array}$ & CF 8.2 billion & 7 percent & CF 8.5 billion $(4.2 \%)$ \\
\hline
\end{tabular}

Source: General Budget Directorate

\section{Foreign debt}

The foreign debt of the Union of Comoros remains unsustainable. As of December 31, 2011, the total debt stood at CF 88.4 billion, representing CF 69.143 billion in debt to multilateral lenders and CF 19.315 billion in bilateral debt. The foreign debt represented 343 percent of exports, and the government is striving to speed up the implementation of triggers to accede to the completion point of the HIPC Initiative and thereby obtain some relief from its debt burden.

The stock of debt - debt amount and arrears - was CF 70.483 billion towards multilateral lenders and CF 23.162 billion toward bilateral lenders, which brings the total foreign indebtedness to CF 93.646 billion.

\section{Foreign debt service}

As of December 31, 2011, debt service totaled CF 2.7 billion, with CF 2.7 billion to multilateral lenders and CF 0.4 billion to bilateral lenders. The increase of CF 0.1 billion over the figure for 2010 is explained by the fact that in 2010 Comoros obtained a deferment of payment bearing on USD 0.24 million.

\section{Investment rate}

The economic activity of the Union of Comoros has taken place within a context of economic recovery at the international level. That state of affairs had a relatively positive effect on the standard of living of populations. Economic activity grew moderately, at a rate of 2.6 percent, compared to 2.2 percent in 2010 . 


\section{Primary budget balance as a percentage of GDP}

One of the authorities' priorities was a target for the primary budget balance as a percentage of GDP of less than 1 percent. Execution of government financial operations was marked by a clear improvement in the primary balance, which posted a surplus equal to 1.6 percent of GDP, in contrast to the deficit of 1.6 percent of GDP in 2010. This change resulted from the improvement in government revenues that reached 16.1 percent of GDP, including 3 percent of GDP in nonrecurring revenues under the economic citizenship program, compared to total revenues of 14.3 percent of GDP in 2010. The wage bill was reduced to a level more compatible with the ability to mobilize government domestic revenues ( 8.5 percent of GDP) following cancellation of the wage increase granted in 2010 .

\section{Government revenue}

As the result of more sustained mobilization efforts at end-2011, government revenue reached 16.1 percent of GDP, including 3 percent of exceptional economic citizenship revenues, compared to a revised forecast of 13.1 percent of GDP and actual performance of 14.3 percent of GDP in 2010. The wage bill was reduced to a level more compatible with the ability to mobilize government domestic revenues ( 8.5 percent of GDP) following cancellation of the wage increase granted in 2010. Consequently, the primary budget balance showed a surplus equal to 1.6 percent of GDP, compared to the deficit of 1.6 percent of GDP in 2010.

\section{External current account}

In 2011 the deficit of the external current account deepened significantly, after remaining unchanged in 2010. It is estimated at nearly 9.5 percent of GDP for 2011 ( 7.0 percent of GDP in 2010), reflecting the increases in world prices for foodstuffs and petroleum products, the recovery of imports linked to direct foreign investment, and a slight drop in financial flows in the form of budget supports. Gross transfers of funds from Comorians living abroad continued to advance modestly, and foreign exchange reserves remained at a comfortable level, equal to 6.4 months of imports of nonfactor goods and services.

\section{Industrial production index}

This indicator has never been calculated. The government is working with the assistance of the ADB to calculate the indicator; results are expected in 2013.

\section{Sector financing}

The government finance sector enjoys the support of the African Development Bank through its Institutional Capacity Building Project (PRCI), in the amount of USD 166.4 million, combined with the Program in Support of Economic Reforms and Financial Governance (PAREGF), in the amount of [units of account] 2 million, and the World Bank, through its project in support of good economic governance (AGBE), in the amount of USD 95.8 million. 


\begin{tabular}{|l|c|c|}
\hline \multicolumn{1}{|c|}{ Outcome indicator } & 2011 target & $\begin{array}{c}\text { Performance/trend } \\
\text { for 2011 }\end{array}$ \\
\hline $\begin{array}{l}\text { Number of Commerce } \\
\text { Ministry managers trained }\end{array}$ & 4 & 11 \\
\hline
\end{tabular}

\begin{tabular}{|r|l|r|}
\hline \multicolumn{1}{|c|}{ Donors } & \multicolumn{1}{|c|}{ Activity } & \multicolumn{1}{c|}{$\begin{array}{c}\text { Amount } \\
\text { (KMF Millions) }\end{array}$} \\
\hline PRCI/BAD & $\begin{array}{l}\text { Institutional capacity building of } \\
\text { financial agencies }\end{array}$ & 166.4 \\
\hline AGDE Project/World Bank & Good economic governance & 95.8 \\
\hline Total & & $\mathbf{2 6 2 . 2}$ \\
\hline
\end{tabular}

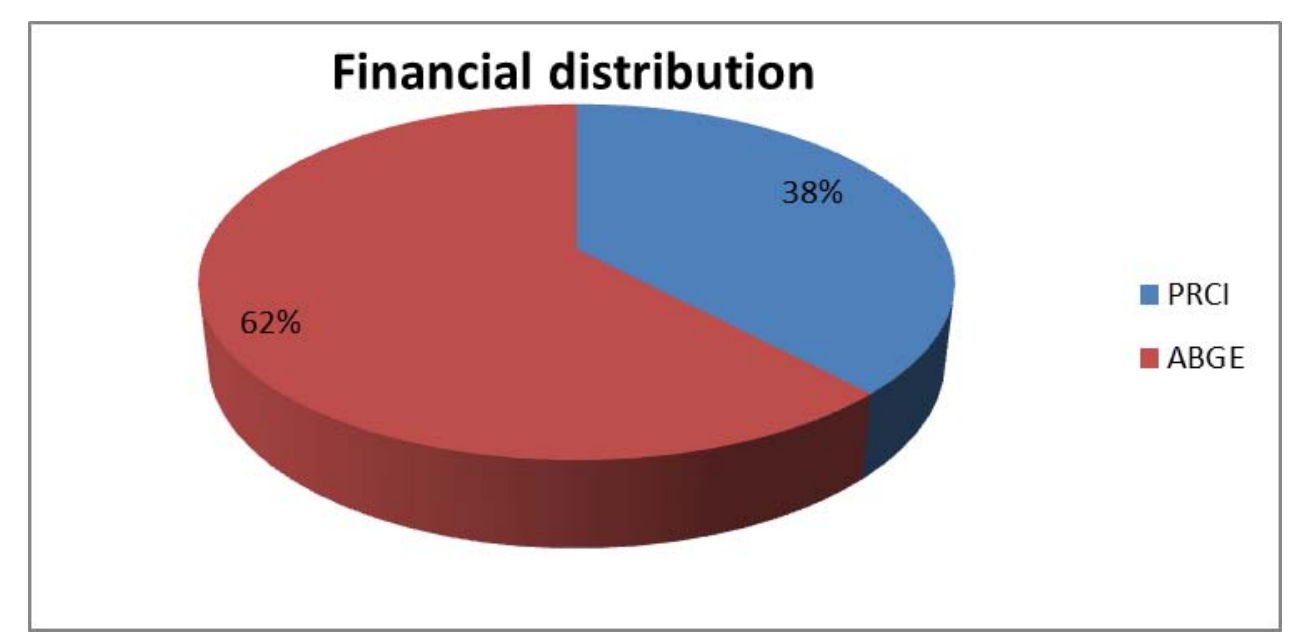


Triggers

\section{Poverty Reduction and Growth Strategy Paper}

- Satisfactory implementation of the full PRGSP for at least on year, as confirmed by an Annual Progress Report submitted by the government to the IMF and the IDA.

\section{Macroeconomic stability}

- Maintain macroeconomic stability: confirmed by satisfactory establishment of ECF arrangement supported by the IMF.

\section{Management of public finance and governance}

- Produce on a regular quarterly basis a detailed report on budget execution over a period of at least 12 months prior to achievement of completion point.

- Adopt the reference terms for an integrated, complete, and computerized feasibility study of public finance management, including cost estimates and a schedule for establishing the proposed system.

- Adopt the law on government contracts compliant with COMESA standards and generate the corresponding implementation rules; enforce the new code in satisfactory fashion prior to arriving at the HIPC completion point.

- Adopt the revised internal framework (organizational chart and staff assignment plan) compliant with the amendment of the constitution of 2009, for all ministries.

- Government approval and submission to Parliament of draft law creating the Court of Accounts, mandated by the constitution to provide external auditing of budget operations. (1)

\section{Structural reforms}

- Adopt the official reform strategies to strengthen the management of Comoros Telecoms (telecommunications), of Societe Comorienne des Hydrocarbures (importing and storing hydrocarbon products), and MAMWE (utilities); and launch bids to identify a strategic partner for at least one of the three companies.
Progress

Instead of a global report as in 2010 , sectoral reports have been drawn up and have been folded into a consolidated report.

March 2012: evaluation mission for the 3rd and 4th Extended Credit Facility (ECF) completed.

Public finance report and minutes available.

Terms of reference adopted. In addition, the outline guide for computerizing financial administration is now available.

Government contracting code adopted

Internal framework adopted

Supreme Court operational.

Accounts section consists of 3 chambers: (Verification, Budgetary discipline and Decision).

Comoros Telecoms: Consensus on the road map with the World Bank ;

- SCH: Business Plan and promotion pending Mamwe: Strategic partnership agreement with Saudi group AlSharif

Software program available. Two agents trained. Schedule for installing software remains to be 
- Produce detailed annual reports on the domestic and foreign debt not later than six months after year's end, including data on existing inventories, new lending and debt service due and paid out. At least one report of this type should be

Draft decree is circulating but held up pending census of FOP agents and internal frameworks.

- Revise the year 2003 decree (Decree No. 03-62/PR) establishing the debt management office, refocus on its activities and its mission, while taking into account the office's capacity constraints.

State of affairs regarding HIPC Initiative triggers:

\section{Satisfactory implementation of the full PRGSP}

Sectoral and consolidated reports are drawn up and will be submitted to the IMF by the government in June 2012.

\section{Macroeconomic stability}

Macroeconomic stability maintained, as confirmed by satisfactory implementation of program for Enlarged Credit Facility. In that context, the $3^{\text {rd }}$ review of the ECF program was satisfactory and was validated by the IMF evaluation mission.

\section{Public finance management}

The public finance report and minutes have been drawn up and made available. The terms of reference for a feasibility study regarding an integrated, comprehensive, and computerized system for managing public finance has been generated and adopted. In addition, the study on the blueprint for computerizing financial administration is available. The Supreme Court is operational. The accounts section consists of 3 chambers:

Verification, Budget discipline, and Decision. The government procurement contract code and internal frameworks have been adopted.

\section{Structural reforms}

Discussions have begun between the government and the World Bank regarding the road map for privatization of Comoros Telecom. A strategic partnership agreement has been signed between the government and the Saudi Group Al-Sharif regarding MAMWE.

\section{Debt management}

Implementation of the debt management system is ongoing and the 2003 decree creating the Debt Directorate has been revised. The year 2010 annual report has been drawn up and published. 


\section{Outlook and recommendations}

The following recommendations have been formulated after completion of the analysis:

- Maintain budgetary discipline in order to stay within the structural guidelines of the program in 2012.

- Promote the values of rigor, integrity, transparency, and effectiveness in public affairs.

- Strengthen the mechanisms for managing and monitoring public finance.

- Broaden the tax base, improve recovery, and ensure the security of receipts.

- Introduce a results-based approach in budget preparation and execution.

- Prioritize resources in the direction of high-impact sectors, with a view to achieving the development priorities of the Comoros.

- Support the Ministry of Finance with respect to state of the art computer equipment and specialized software.

- Train sectoral managers in the use of tools for controlling public expenditures (budget framework, TOFE generation, etc.).

- $\quad$ Speed up the process for drawing up a Medium-Term Expenditure Framework (MTEF).

\section{b) Trade}

The PRGSP calls for integration and facilitation of domestic and foreign trade. Implementation of the PRGSP in the sector in 2011 was characterized by:

- creation of a Trade Arbitration Center;

- transition from presumptive customs duties to ad valorem taxation;

- an order creating an office of certification of origin.

\section{Breakdown of priority indicators}

Between 2010 and 2011, the value of exports increased by 16 percent: CF 8.9 billion in 2011 compared to CF 7.7 billion in 2010 . 


\begin{tabular}{|l|l|l|l|l|l|l|}
\hline & $\mathbf{2 0 0 6}$ & $\mathbf{2 0 0 7}$ & $\mathbf{2 0 0 8}$ & $\mathbf{2 0 0 9}$ & $\mathbf{2 0 1 0}$ & $\mathbf{2 0 1 1}$ \\
\hline Exports (KMF millions) & 4,089 & 4,912 & 2,190 & 4,230 & 7,655 & 8,908 \\
\hline Imports (KMF millions) & 45,189 & 49,716 & 60,323 & 74,532 & 86,482 & 97,935 \\
\hline $\begin{array}{l}\text { Trade balance (KMF } \\
\text { millions) }\end{array}$ & $-41,100$ & $-44,804$ & $-58,133$ & $-70,302$ & $-78,827$ & $-89,027$ \\
\hline Coverage rate & 9.05 & 9.88 & 3.63 & 5.68 & 8.85 & 9.10 \\
\hline
\end{tabular}

Source: Central Bank of the Comoros

In the course of the last three years, the value of Comoros exports has increased, on average, by 63 percent, the result of buoyant external demand and favorable export prices for cloves.

Meanwhile, the value of imports has risen to CF 97.9 billion, an increase of 13 percent compared to the value in 2010. This state of affairs has worsened the trade balance but improved the degree of openness of the economy from 47 percent in 2010 to 52.0 percent in 2011, with the coverage rate of imports by exports rising from 8.9 percent to 9.1 percent over the same period.

\begin{tabular}{|l|c|c|}
\hline \multicolumn{1}{|c|}{ Results indicator } & 2011 target & $\begin{array}{c}\text { Performance/trend } \\
\text { in 2011 }\end{array}$ \\
\hline $\begin{array}{l}\text { Number of managers in Ministry of Trade } \\
\text { trained }\end{array}$ & 4 & 11 \\
\hline
\end{tabular}

Source: General Directorate for Trade (Human Resources Department)

Eleven managers from the Ministry of Trade benefited from short- or long-term training devoted to economic and/or commercial policy. Financing was provided by either UNCTAD, through its CIR project, or by WTO. The sectoral target for training was exceeded.

\begin{tabular}{|l|c|c|}
\hline \multicolumn{1}{|c|}{ Results indicator } & 2011 target & $\begin{array}{c}\text { Performance/trend } \\
\text { in 2011 }\end{array}$ \\
\hline Laws passed & 1 & 2 \\
\hline
\end{tabular}

Source: General Directorate for Trade (Human Resources Department)

In 2011 two laws were implemented. The first enables the transition from customs duties calculated as lump sums to an ad valorem taxation system, and the second enabled implementation by order of an Office of Certification of Origin.

However, the Budget Law, which called for free entry of products originating in the COMESA region, was not implemented.

\section{Sector financing}

\begin{tabular}{|c|c|c|}
\hline Donors & Activities & $\begin{array}{c}\text { Amount (in } \\
\text { KMF millions) }\end{array}$ \\
\hline Union of Comoros & Technical and material support & 98.25 \\
\hline CIR/UN system & Capacity building & 21.00 \\
\hline Total & & $\mathbf{1 1 9 . 2 5}$ \\
\hline
\end{tabular}




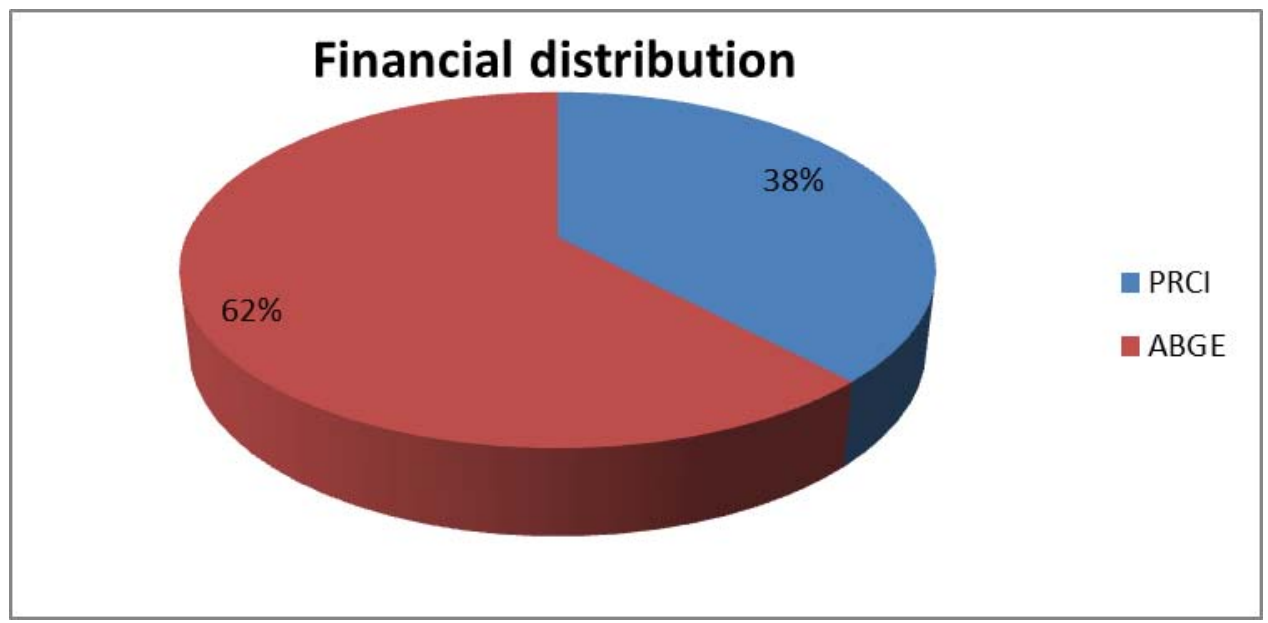

\section{Outlook and recommendations}

It is abundantly clear that development of the private sector requires improvement of the business climate and strengthening its competitiveness in order to be prepared to respond to the challenges of economic and trade openness to which Union of Comoros is committed.

Accordingly, the Customs/Economy-Trade Committee that has been implemented must be given formal status by a ministerial order and extended to include the transportation sector.

Along with its commitment to ensuring the autonomy of women, the Union of Comoros must develop income-generating activities and women's entrepreneurship, as well as looking into opportunities presented by the COMESA market.

\section{c) Energy}

The PRGSP aims at improving the supply of low-cost energy by means of:

- strengthening the institutional, organizational, and management framework of the energy sector;

- strengthening energy storage, generation, and distribution infrastructures;

- boosting energy efficiency and broadening alternatives to wood for heating;

- diversifying energy sources.

Salient features of the sector in 2011 included:

- strengthening the institutional framework with the technical and financial support of several development partners, including the ADB, UA, UE, COMESA, World Bank, and UNIDO; 
- noteworthy progress in enlarging networks and increasing number of hook-ups to the power grid throughout the 3 islands, using public funding;

- restoration of financial and organizational auditing of MAMWE and $\mathrm{SCH}$;

- creation of a Training Plan;

- dilapidated condition of existing installations and networks;

- establishing and equipping the General Directorate and regional directorates;

- protracted electrical power outages on all of the three islands, especially on Grand Comoro.

\section{Breakdown of priority indicators}

\begin{tabular}{|l|c|c|}
\hline \multicolumn{1}{|c|}{ Results indicator } & 2011 target & 2011 performance \\
\hline Electrification rate & 50 percent & 45 percent \\
\hline Technical loss rate & 38 percent & 20 percent \\
\hline Rate of commercial losses & 15 percent & 30 percent \\
\hline Cost to consumer of $1 \mathrm{kWh}$ & KMF 132 & KMF 132 \\
\hline
\end{tabular}

Source: MAMWE 


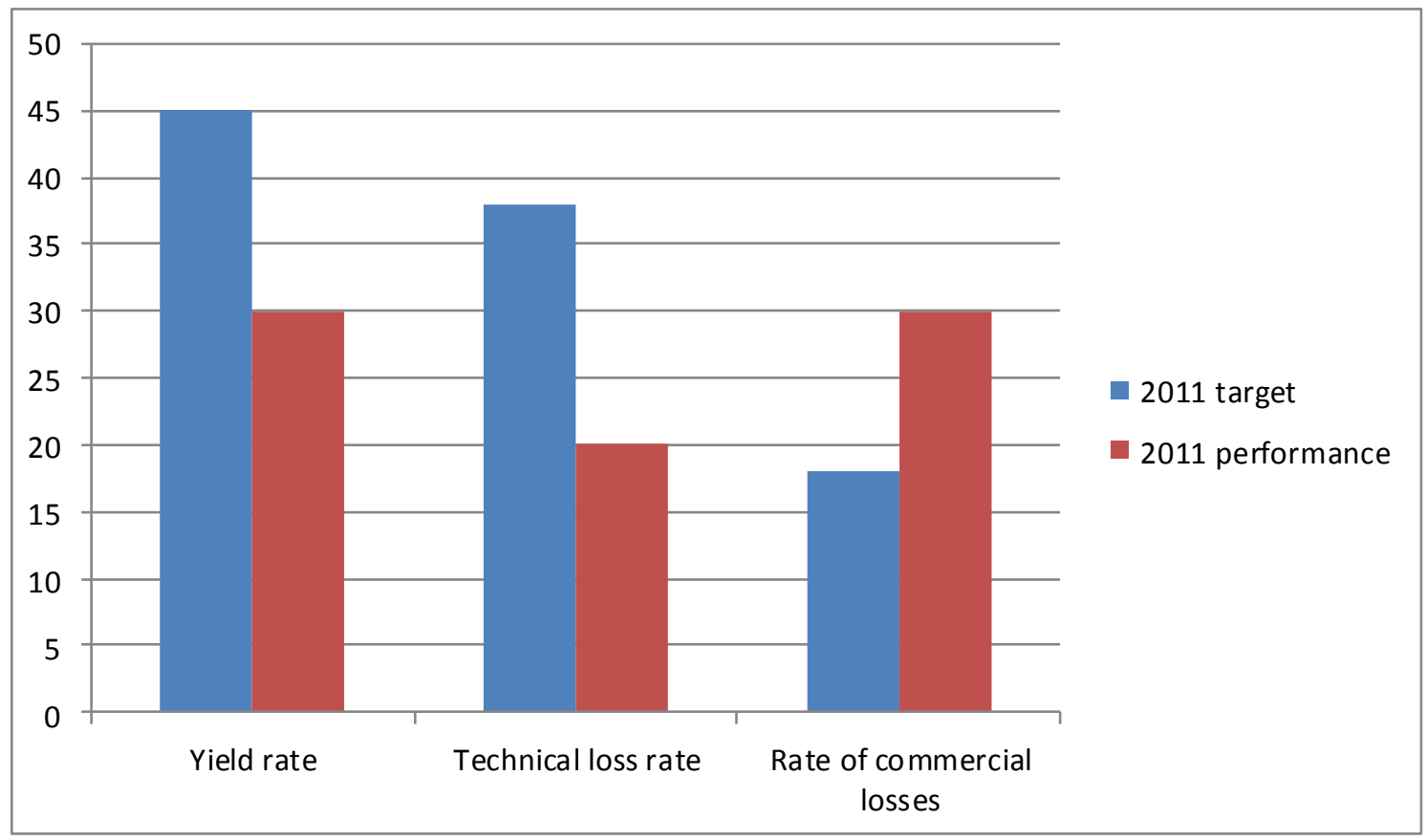

Source: Energy Directorate

As the chart shows, the energy yield rate (30 percent) fell below targets set for 2011. This trend is explained by the dilapidated condition of the power grid, which cause high losses in the transport and distribution of electricity (10 percent). Moreover, these losses are clearly caused by substantial losses outside generating plants, estimated at an additional 10 percent.

Consumer fraud, failure to enforce the rules related to theft of electricity, as well as technical failures (logistic and computer-related) at MAMWE are the sources of enormous commercial losses, estimated at 30 percent. Meters equipped with card swipers, originally thought to be the solution to this problem when fully implemented, have not always produced the expected results.

\section{Electrification rate}

The country-wide electrification rate stands at 45 percent, below the 50 percent targeted in 2011. Despite the failure to achieve the expected result, it must be said that several efforts have been made to extend the grid and hook-ups to electrical power. Of the three islands, the highest rate of coverage is on Mohéli (70 percent). The Comorian government, through economic citizenship funds, remains the greatest contributor.

\section{Cost to the consumer of $1 \mathrm{kWh}$ of electricity}

The sustained increase on the international hydrocarbon products markets has not been passed on to the consumers in the Union of Comoros. The government has subsidized the sector to keep the cost of $1 \mathrm{kWh}$ of electricity unchanged, despite the resulting cash flow problems at SCH and MAMWE. Accordingly, the cost of $1 \mathrm{kWh}$ of electricity has remained unchanged at CF 132 from 2010 to 2011. 


\section{Sector financing}

Several technical and financial partners have supported the energy sector in response to the plea made by the government.

\begin{tabular}{|l|l|r|}
\hline \multicolumn{1}{|c|}{ Donor } & \multicolumn{1}{|c|}{ Activity } & \multicolumn{1}{c|}{$\begin{array}{c}\text { Amount } \\
\text { (CF millions) }\end{array}$} \\
\hline EU/WB & Completion of the national energy strategy & 40 \\
\hline Kuwait & Geothermal feasibility study & 200 \\
\hline ADB & Institutional support (AEPA) & 200 \\
\hline People's Republic of China & Installation of new groups & 200 \\
\hline People's Republic of China & Installation of 500 household solar panels & 1,100 \\
\hline Economic citizenship funds & Extension of MT/BT networks & 1,000 \\
\hline $\begin{array}{l}\text { FEM; PNUE; UNIDO; } \\
\text { COMESA; EU }\end{array}$ & $\begin{array}{l}\text { Research and promotion of renewable } \\
\text { energy }\end{array}$ & 250 \\
\hline Al-Sharif; Sudan; IR of Iran & $\begin{array}{l}\text { Implementation of the national energy } \\
\text { strategy }\end{array}$ & $\mathbf{2 , 9 7 0}$ \\
\hline \multicolumn{2}{|c|}{ Total } & \multicolumn{2}{|c}{} & \multicolumn{2}{|c|}{} \\
\hline
\end{tabular}

Source: General Directorate for Energy and Water

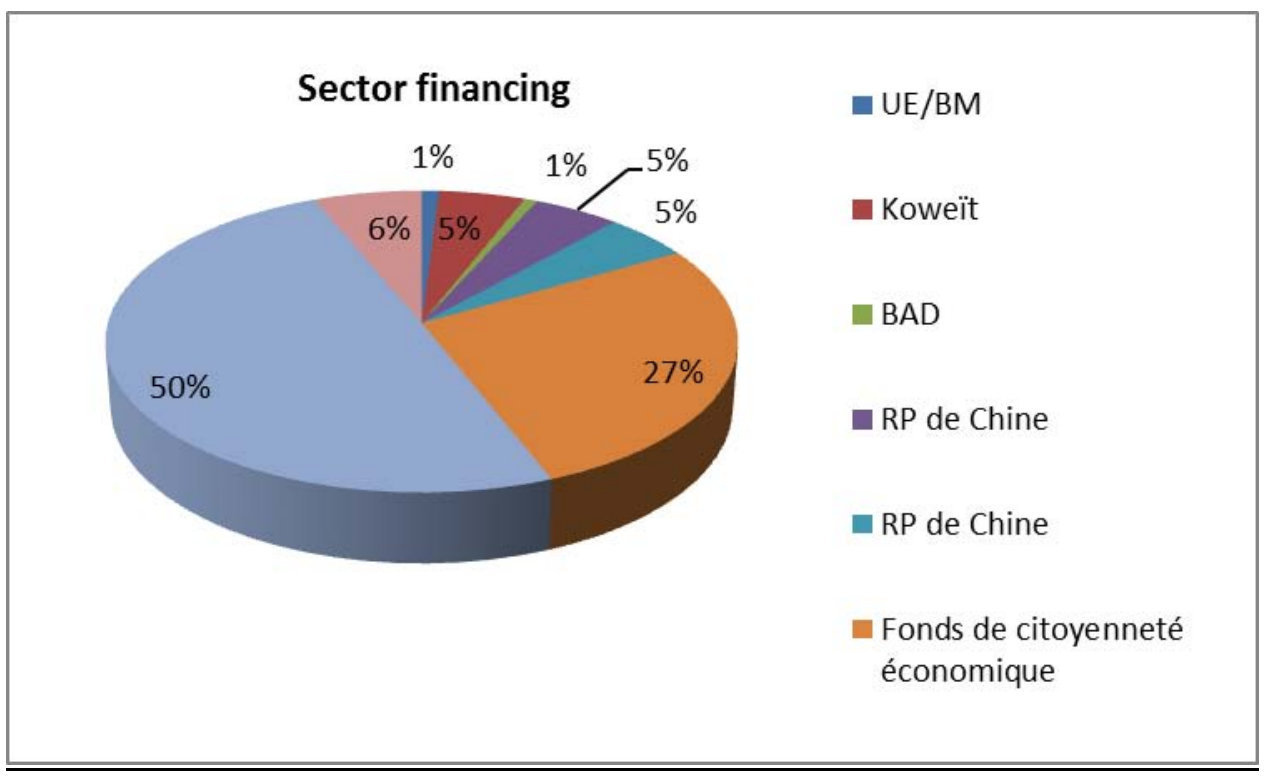

[donor list, right column, top to bottom: EU/WB; Kuwait; ADB; People's Republic of China; People's Republic of China; Economic citizenship funds]

\section{Outlook and recommendations}

The energy sector hosts a number of initiatives from development partners: 
- The African Development Bank (ADB) is involved within the framework of its country program to assist the energy sector in the Union of Comoros.

- The Al-Sharif group has signed a strategic partnership agreement with the Union of Comoros to boost its production capacity and has provided assistance to train local technicians.

- The European Union has also helped in completing a strategy document and an action plan covering a period of 20 years, and to help with the installation of a solar park on Mohéli.

- Other partners, including the UNDP through its GEF funds and the World Bank, have mobilized to assist Comoros in finding reliable solutions to problems related to providing energy at less cost.

In light of the visible constraints, some recommendations have been reformulated:

- rehabilitate and review the already installed facilities in order to boost their production capacity;

- $\quad$ speed up the installation of the facilities offered by China;

- $\quad$ speed up completion of the feasibility studies on geothermal sources;

- update the studies on hydroelectric potential on Anjouan and Mohéli;

- complete the feasibility studies on the wind potential of the three islands.

\section{d) infrastructure}

In the infrastructure sector, the government has designated as its priority objective to improve basic infrastructures and communications services by: improving the security of the road network; constructing and updating standards for ports and airports; constructing administrative buildings and public housing; and promotion of information technology for communications serving development.

Highlights in the sector include:

- validation and finalization of the new Road Maintenance Strategy spread out over five years, with financing from the tenth meeting of the European Development Fund (EDF), devoted to ensuring current and periodic upkeep of the national road network;

- specification of the sectoral policy for transportation in the Union of Comoros out to the year 2030; Law No. 11-025/AU dated December 29, 2011 on the sustained development program for the transportation sector;

- $\quad$ start of PADST activities and incorporation of technical assistance; 
- approval of the law on sectoral policy for transportation;

- approval of Law No. 11-026/AU dated December 29, 2011 related to the Urbanism and Construction Code in the Comoros;

- wreck of the inter-island coastal vessel Madjiriha (around sixty victims).

\section{Breakdown of priority indicators}

\begin{tabular}{|l|r|r|r|}
\hline \multicolumn{1}{|c|}{ Priority indicators } & \multicolumn{1}{c|}{$\begin{array}{c}\text { 2010 } \\
\text { reference value }\end{array}$} & 2011 target & $\begin{array}{c}\text { 2011 } \\
\text { performance }\end{array}$ \\
\hline Percentage of accidents & $80 \%$ & $70 \%$ & $84 \%$ \\
\hline Resurfaced national roads & $\mathrm{NC}$ & $5 \mathrm{~km}$ & $19 \mathrm{~km}$ \\
\hline Resurfaced regional roads & $\mathrm{NC}$ & $55 \mathrm{~km}$ & $7 \mathrm{~km}$ \\
\hline Resurfaced city streets & $\mathrm{NC}$ & $25 \mathrm{~km}$ & $3.5 \mathrm{~km}$ \\
\hline Airports fenced & 1 & 1 & 3 \\
\hline Air passenger traffic & 239,881 & 256,673 & 254,273 \\
\hline Port passenger traffic & 38,084 & 40,749 & 38,260 \\
\hline Rate of telephone subscriptions & $54 \%$ & $75 \%$ & $59 \%$ \\
\hline Constructed administrative buildings & $\mathrm{NC}$ & 10 & 95 \\
\hline Affordable housing offered & $\mathrm{NC}$ & 90 & 65 \\
\hline
\end{tabular}

Source: National Infrastructure Directorate

\section{Number of injuries per accident}

Accidents and bodily injuries are on the rise, from 80 percent in 2010 to 84 percent in 2011 , compared to a target figure of 70 percent. This state of affairs is attributable for the most part to the dreadful condition of the roads, particularly outside the city of Moroni.

Actions have been undertaken by the relevant authorities, with the assistance of technical and financial partners to improve the condition of our road infrastructures. With the Economic Citizenship Fund, the government has completed several projects that add improvements to this indicator, for example, the rehabilitation and restructuring of $3.5 \mathrm{~km}$ of city streets in Moroni, which smoothed out its vehicle circulation. The Road Upkeep Fund (FER) maintained roads in the Moroni-Hahaya corridor, the busiest traffic corridor.

\section{Road rehabilitation}

The government has also set as a sectoral priority rehabilitation of highly damaged roads. It has undertaken a vast program financed by the Economic Citizenship Fund to rehabilitate $41 \mathrm{~km}$ covering access in the Anjouan basin.

The technical and financial partners have supported the efforts made by the authorities. The French Development Agency (AFD) financed the asphalting of the Hajoho-Jimilime road, connecting a region with strong economic potential, and Qatar has taken up a position regarding road building.

Nevertheless, it needs to be underscored that the performances have fallen short of the targeted objectives for the year under study. In addition to slow government procurement contract processing, there have been problems in mobilizing resources. 


\section{Rate of telephone subscriptions}

The subscriber rate rose to 59 percent in 2011, from 54 percent in 2010. This slight increase is explained by an improvement in the network resulting from investments made in 2010. In addition, the ADSL product has been added to the network. The lack of sector openness deprives the users of products of higher quality at competitive prices.

\section{Number of passenger arrivals at Hahaya International Airport}

In 2011, the number of passenger arrivals rose by 6 percent, from 239,881 in 2010 to 256,673 . This result fell below the forecast made, and is attributable to more rigorous controls of aircraft resulting in grounding of a certain number of them.

\section{Number of passenger arrivals in the new port of Moroni}

The wreck of the inter-island coastal vessel forced the port authority to strengthen inspections of coastal vessels. Port traffic rose slightly, by 6 percent compared to 2010 . The number of passengers increased from 38,084 to 38,260. More rigorous inspections of coastal vessels explain the shortfall of the target for passenger arrivals set at 40,749.

\section{Number of administrative buildings built/rehabilitated}

Within the framework of strengthening the rule of law, administrative buildings have been built and/or rehabilitated in the course of 2011. Courtrooms have been built/rehabilitated in various courthouses, island council meeting houses have been built on Mohéli and on Anjouan, weather bureaus and the Office of Tourism have also been built.

Affordable housing has been constructed with the support of the Housing Agency (clay brick experiment).

Comoros Telecom has built commercial offices in some localities using its own funds.

\section{Sector financing}

\begin{tabular}{|l|l|r|}
\hline \multicolumn{1}{|c|}{ Donor } & \multicolumn{1}{c|}{ Activity } & Amount (CF millions) \\
\hline Union of Comoros & Building infrastructure & 4,819 \\
\hline European Union & Road infrastructure & 600 \\
\hline France/AFD & Road infrastructure & 162 \\
\hline Total & & $\mathbf{5 , 5 8 1}$ \\
\hline
\end{tabular}




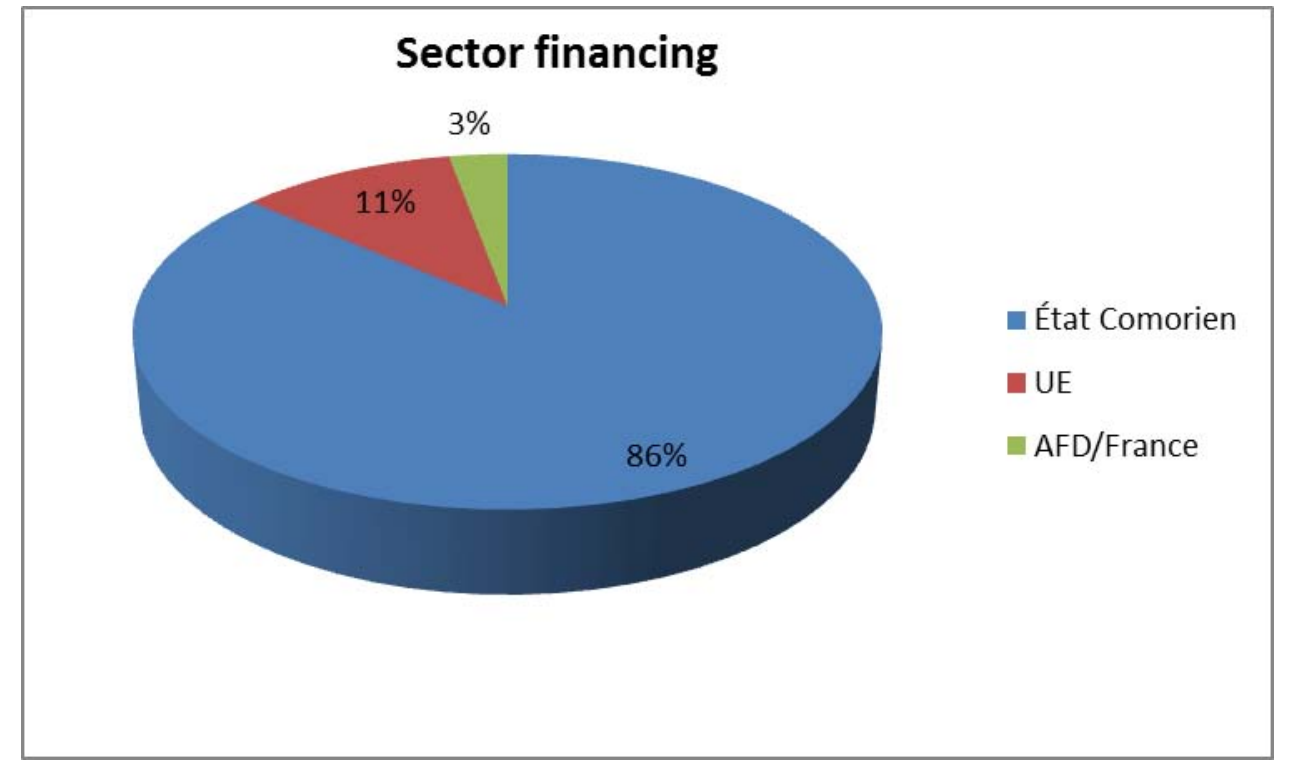

[Donor list, right column, top to bottom: Union of Comoros; European Union; France/AFD]

\section{Outlook and recommendations}

Programs and projects involving several technical and financial partners are being implemented. The roads subsector is experiencing an unprecedented condition of degradation for lack of regular maintenance and adequate allocations of budget resources, and, in addition, investment in new construction, rehabilitation and restructuring of old trunk routes dependent on contributions from foreign donors.

The ports and airports sector recorded significant investments that are nevertheless inadequate to boost the level and quality of subsector infrastructures to match needs and requirements.

The subsector of telecommunications is experiencing problems related to equipment ill adapted to the system, an uncontrolled expansion, poor performance of services provided, and poor financial governance of the chief public operator. On the other hand, the subsector is expanding very rapidly and the chief public operator has made capital investments from its own resources up to this point, while benefiting from financing at concessional conditions from China, to make the fiber optic network operational; the underwater cable for the network is already laid but is not yet operational. We make the following recommendations:

- mobilize the resources promised at the Doha Conference for this sector, as well as the resources from other development partners;

- ensure strengthening of the capacities of the road brigade;

- make cooperation between the national Gendarmerie and the national police force operational in regard to controlling the highways;

- update secondary airport landing strips to meet security standards; 
- establish a national air and maritime transportation company;

- speed up the opening of the sector to private operators able to bring to the sector the necessary investments for expansion, efficiency, and effectiveness;

- draw up a blueprint for land use management incorporating the following dimensions: road, port, and airport infrastructures; telecommunications; energy; water conveyance; environment and quality of life; economic activity zones;

- draw up a strategy for national and external financing of equipment arising from the blueprint;

- restock the road maintenance funds on a regular basis as a form of national support to the Public Investment Program (PIP);

- improve access to telecommunications and radio-television services at a competitive price;

- establish a committee to coordinate donors.

\section{e) Water and sanitation}

The PRGSP seeks to improve access to drinking water and sanitation facilities and to manage the resource on a sustainable basis by proceeding as follows:

- strengthen the institutional, regulatory, and management framework of the sector of water and sanitation;

- strengthen planning and review of impact indicators;

- implement the national program for access to drinking water;

- implement the sanitation program;

- nationalize integrated management of the water resource.

Sector highlights in 2011:

- construction of a network $23 \mathrm{~km}$ in length;

- 9 drilling and harnessing stations hooked up to the network;

- implementation of a sanitation and water program for 300 households;

- strengthening of the regulatory, legal, and institutional framework with the support of the African Development Bank (BAD). 


\begin{tabular}{|l|r|r|}
\hline \multicolumn{1}{|c|}{ Results indicators } & 2011 target & Performance \\
\hline Rate of access to potable water & $20 \%$ & $11 \%$ \\
\hline $\begin{array}{l}\text { Number of households benefiting from a } \\
\text { sanitation program }\end{array}$ & 200 & 300 \\
\hline Length of new network construction $(\mathrm{km})$ & 22 & 23 \\
\hline
\end{tabular}

Source: General Energy and Water Directorate

\section{Percentage of the population having access to a source of potable water}

No improvement was observed in the number of people having access to a source of potable water. In spite of the new constructions of water conveyance networks and drilling stations in community contexts, the rate of access has not advanced. This delay is due in the first place to the lack of a system for analyzing and treating water in rural districts. The lack of a government investment in this regard constitutes a big obstacle.

We note that the rate of access to potable water (11 percent) reflects only observations made in the city of Moroni water supply network.

\section{Number of households benefiting from a sanitation program}

The number of households benefiting from a sanitation program is 300 . This figure exceeds the target set for the year 2011. The sanitation activities undertaken by the PAEPA project of the BAD remain the key argument in favor this development.

\section{Length of the newly built water network $(\mathrm{km})$}

The built water network has reached $23 \mathrm{~km}$, exceeding by one kilometer the projections of 2011. This performance is explained by the implementation of the rural area water conveyance program financed by AFD. This program is active at Djando on Mohéli and Domoni and Sima on Anjouan.

Sector financing

\begin{tabular}{|r|l|r|}
\hline \multicolumn{1}{|c|}{ Donor } & \multicolumn{1}{c|}{ Activity } & \multicolumn{1}{c|}{$\begin{array}{c}\text { Amount (in } \\
\text { KMF millions) }\end{array}$} \\
\hline BAD & Access to potable water program (AEP) & $1,512,500$ \\
\hline AFD & Oichili AEP project & 800 \\
\hline & & $\mathbf{1 , 5 9 2 , 5 0 0}$ \\
\hline
\end{tabular}

Source: General Energy and Water Directorate 


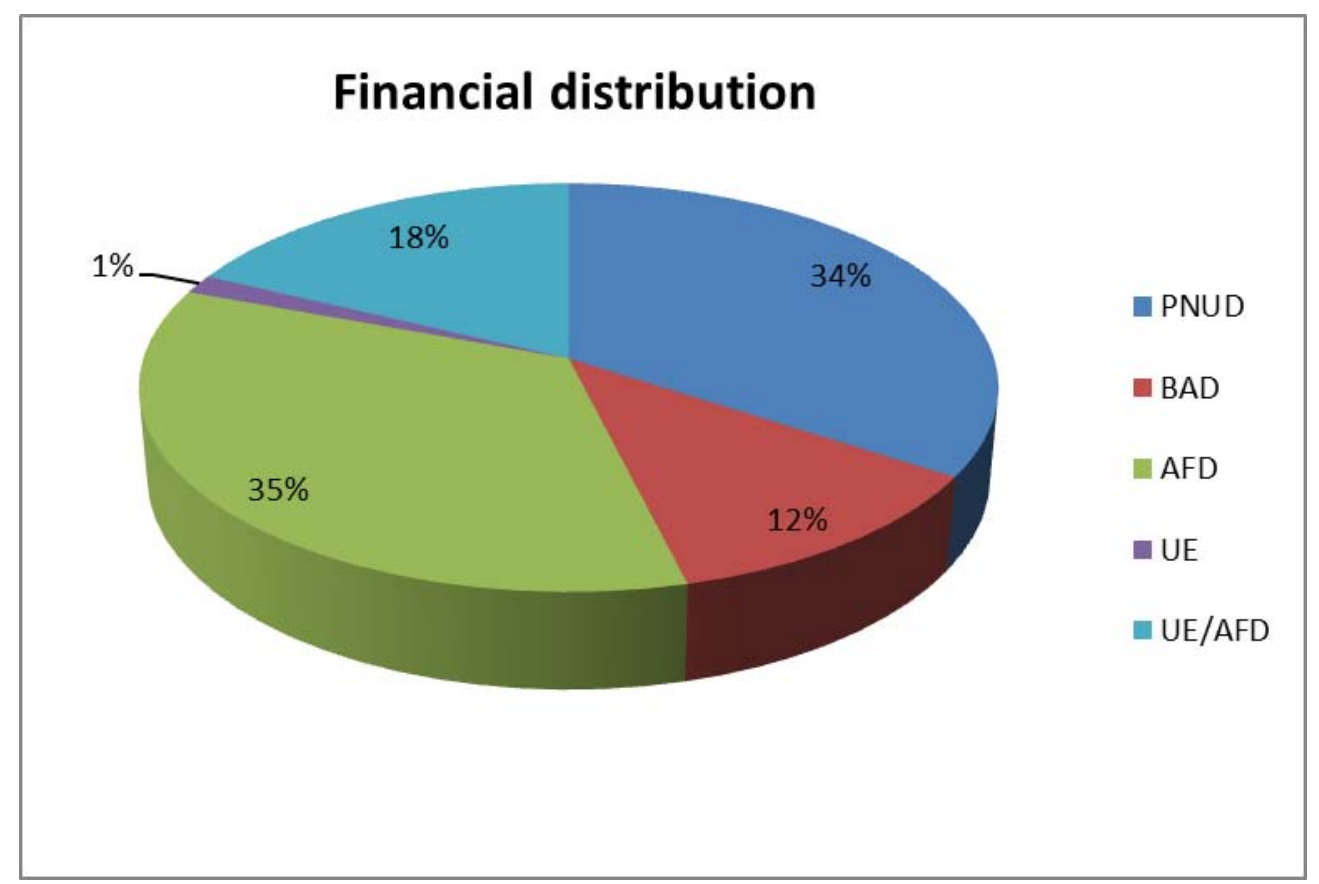

[Donor list, right column, top to bottom: UNDP; $A D B ; A F D ; E U ; E U / A F D]$

\section{Outlook and recommendations}

The Comorian government has issued a very strong signal with a view to promoting the sector, as reflected in donor outreach and mobilization;

- AFD and EU will finance the AEP in Domoni in the amount of CF 6 million.

- The Islamic Republic of Iran will implement a well equipment program on Ngazidja.

- Upcoming launch of a project to protect water resources from the effects of climate change, financed by UNDP;

- Conference on investment and development in the Comoros held in 2010 in Doha, Qatar, with commitments from multiple donors in support of the sector.

The following are recommended:

- $\quad$ speed up the implementation of AEPA project activities;

- $\quad$ speed up the implementation of activities in AEP projects in Sima, Djando, Domoni and Geceau;

- create and implement a regulatory and institutional framework governing the totality of the sector;

- implement a system for analysis and treatment of water in community contexts. 


\section{Core strategy 2: strengthen the profitable sectors by emphasizing institution-building and increased participation of private economic operators}

This core strategy concerns the implementation of priority programs aimed at developing and increasing the productivity of sectors enhancing economic growth and contributing to a lasting reduction of poverty. The sectors involved are, in particular, agriculture, livestock, fishing, and tourism. Although the traditional businesses of the agro-food sector are better know and their contributions to economic development and food security no longer in need of demonstration, the tourism sector offers great potential that has never really been exploited.

\section{a) The private sector}

To develop the private sector, the PRGSP aims at supporting the organization of the private sector and developing financial intermediation and micro lending.

In 2011, the implementation of programs and projects was marked by:

- launch of a broad program of reforms of the business climate, with technical assistance from IFC;

- passage of Law No. 11-007B/AU dated May 3, 2011 and promulgation of Decree No. 12-151/PR of the new Tax Code;

- passage of Law No. 11-027/AU dated December 29, 2011 and promulgation of Decree No. 12-131/PR of the Government Contracts Code;

- Law ratifying the MIGA convention (investment guarantee);

- Law regulating and organizing leasing;

- adoption of a blueprint on inclusive finance;

- creation of the center for administrative formalizing of businesses.

\section{Breakdown of priority indicators}

\begin{tabular}{|l|r|r|}
\hline \multicolumn{1}{|c|}{ Results indicators } & 2011 target & \multicolumn{1}{c|}{$\begin{array}{c}\text { Performance/trend } \\
\text { for 2011 }\end{array}$} \\
\hline Regulatory and legislative documents available & 1 & 3 \\
\hline Number of new businesses in the service sector & 35 & 107 \\
\hline Growth rate of credit to the private sector & $30 \%$ & $8.41 \%$ \\
\hline
\end{tabular}

Source: [source missing]

Three laws were passed and their impact on an improved business climate requires no demonstration. The laws are: the Tax Code, the Urbanism Code, and the Government Contracting Code. 
The World Bank report entitled "Doing Business 2012" changed the place of the Comoros from $159^{\text {th }}$ position to $157^{\text {th }}$ position. This modest improvement took into account only a single domain, namely the transfer of property. In fact, the government, with the technical support of the SFI, launched significant structural reforms aimed at improving the business climate, especially regarding investments (ANPI performs secretarial functions in connection with these reforms). These reforms have affected the areas of: creation of businesses, transfer of property, obtaining loans, and execution of contracts.

Progress in this connection can be measured by a reduction in the time required to create a business (48 hours versus two weeks). The cost of creating a business has fallen from KMF 530,000 to KMF 69,500, with a 17-step process reduced to 2 steps, availability on line of a model company, and the fee for property transfer down from 15 percent to 9 percent. In 2011, out of 411 companies registered with the business registry, 268 were supported by ANPI.

The upward trend in creation of service companies shows the tendency of the national economy to favor the tertiary sector. Overall, 107 new service sector business have been created. The entity AMIE supported 32 small and medium-sized enterprises (PME), lending a total of CF 22,909,000 in the form of small lines of credit for entrepreneurs unable to acquire a guarantee fund. In addition, the Comorian Cash Crop Exporters Association benefited from a strengthening of its capacities from the Strengthened Integrated Framework project in the amount of CF 2.45 million.

Bank lending increased from CF 17.367 billion in 2006 (including CF 13.487 billion to the private sector) to CF 43.704 billion in 2010 (with CF 35.304 billion to the private sector), and to CF 45.852 billion in 2011 (CF 38.275 billion to the private sector).

\section{Changes in bank lending}

\begin{tabular}{|l|r|r|r|r|r|r|}
\hline & \multicolumn{1}{|c|}{$\mathbf{2 0 0 6}$} & \multicolumn{1}{c|}{$\mathbf{2 0 0 7}$} & $\mathbf{2 0 0 8}$ & \multicolumn{1}{c|}{$\mathbf{2 0 0 9}$} & $\mathbf{2 0 1 0}$ & $\mathbf{2 0 1 1}$ \\
\hline Total bank lending (KMF millions) & 17,367 & 19,413 & 27,503 & 37,172 & 43,704 & 45,852 \\
\hline Claims on central administration & 2,871 & 2,938 & 5,246 & 7,266 & 5,743 & 6,016 \\
\hline Credits to the economy & 14,496 & 16,475 & 22,257 & 29,906 & 37,961 & 39,836 \\
\hline Public sector (AdmiLoc and SNFP) & 959 & 1,040 & 2,744 & 1,303 & 2,547 & 1,561 \\
\hline Private sector & 13,487 & 15,385 & 19,463 & 28,050 & 35,304 & 38,275 \\
\hline $\begin{array}{l}\text { Other credits (other public finance } \\
\text { companies) }\end{array}$ & 50 & 50 & 50 & 553 & 110 & -- \\
\hline
\end{tabular}

Source: Central Bank of the Comoros

To be sure, the private sector has received an ever larger volume of bank credits, with annual growth rates moving from 13.65 percent in 2007 to 8.41 percent in 2011, including a spike of 35.10 percent in 2008 . Even though the annual growth rate of lending awarded to the private sector declined from 2008 to 2011 , the rate remained positive all the same. Such weak growth could have been foreseen in the wake of the strong increases of the preceding years, and all the more since the required reserves rate-i.e., blocked bank deposits with the Central Bank of the Comoros - was 30 percent between July 2010 and July 2011. Since July 2011, the rate has been brought down to 25 percent.

Meanwhile, the volume of long-term lending remains thin compared to the total volume of credits granted by the system, thereby limiting the investment capacities of businesses. 
In fact, despite the underperformance of the tertiary sector, commercial activities posted growth of 4.2 percent in 2011, compared to 1.41 percent in 2010. Meanwhile, commercial activities contributed more than 52 percent to the volume of the services sector. It follows that bank lending to the private sector has especially benefited trade, whose credits are for the short term, at the expense of productive activities, which require long-term credits.

\section{Chart 1. Changes in lending to the private sector}

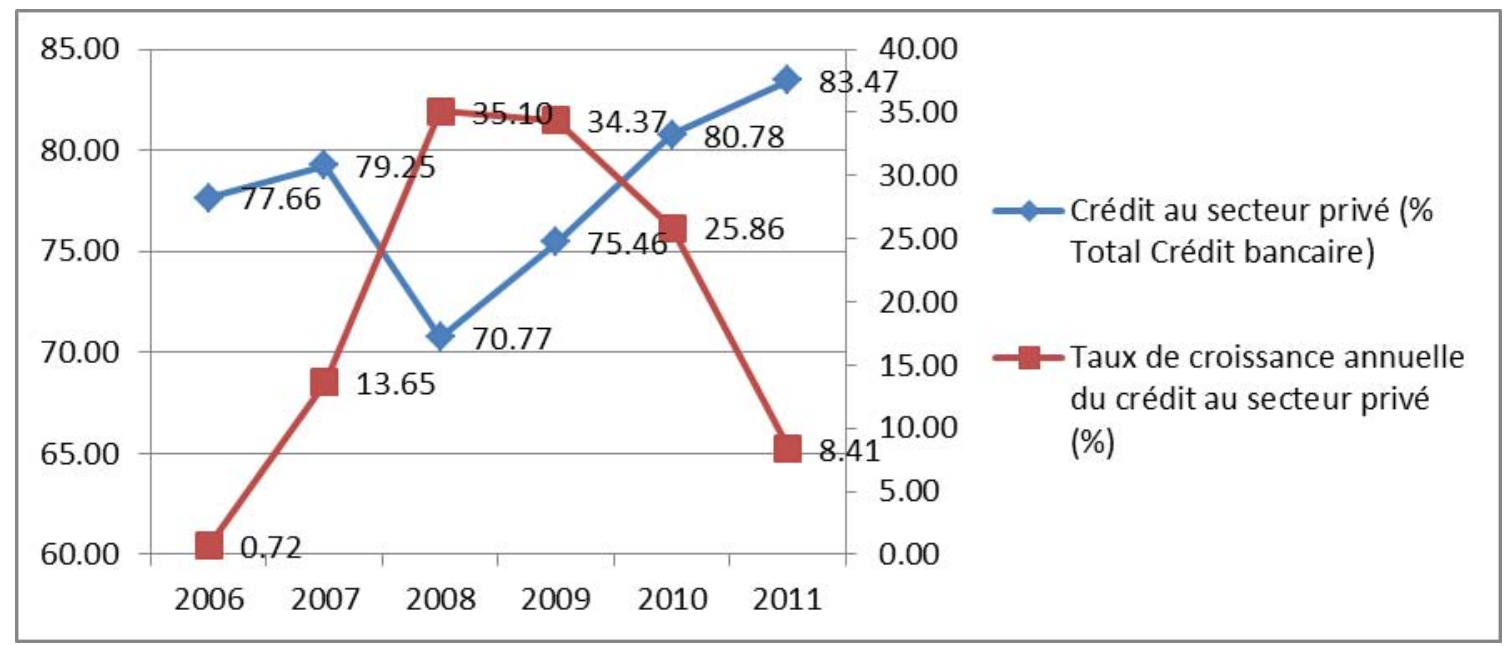

Source: Central Bank of the Comoros

[right column, top to bottom: Credit to the private sector (as a percentage of total bank lending); Annual growth rate of credit to the private sector (percentage)]

As concerns the DTIs, we note the involvement of the French Development Agency (AFD) in the role of technical and financial support (30 percent financing of the Mecks Moroni Building, line of credit placed at the disposal of Mecks and Sanduk). The PAFIC/SNU project supports the DTIs by strengthening capacities and improving the management system. These actions have had the effect of increasing the market share of the DTIs, now standing at 30 percent of the financial sector in the Comoros.

\section{Sector financing}

\begin{tabular}{|c|c|c|}
\hline Donor & Activity & $\begin{array}{c}\text { Amount (KMF } \\
\text { millions) }\end{array}$ \\
\hline PAFIC/UNDP & Microfinance & 50.75 \\
\hline COMESA & Business climate & 35.00 \\
\hline SFI/World Bank & Business climate & 70.20 \\
\hline EIF/UNDP & Capacity building & 2.45 \\
\hline Total & & 158.40 \\
\hline
\end{tabular}

Source: Ministry of Finance 


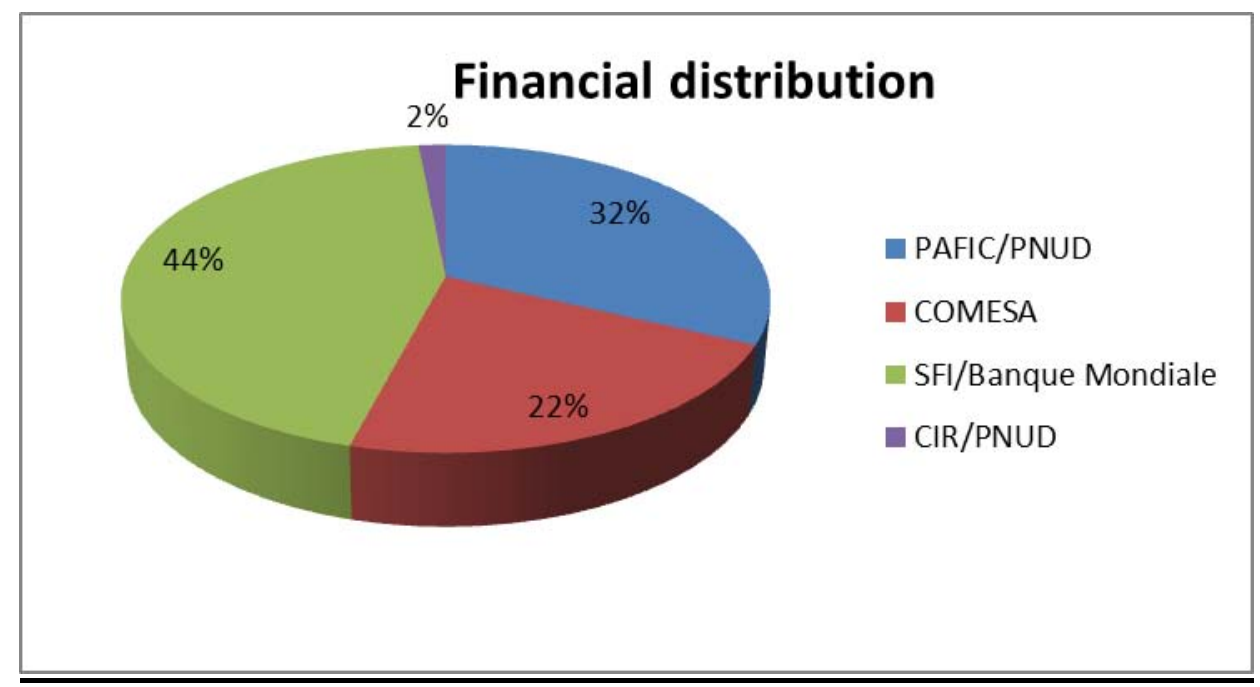

[right column, top to bottom: PAFIC/UNDP; COMESA; IFC/World Bank; EIF/UNDP]

\section{Outlook and recommendations}

As far as recommendations are concerned, we need mainly to recall that one of the sector's problems is support of operators intending to undertake bankable projects at financial institutions, and in particular, large-scale development projects, a problem that arises from the lack of engineering capacity and support institutions.

Moreover, the PRGSP has characterized some sectors as promoters of growth, without specifying the priorities the authorities have in mind vis-à-vis the targeted sectors.

There is therefore good reason to:

- make additional efforts to improve the business climate, strengthen competitiveness so as to be in a position to respond to challenges of the economic and commercial openness to which the Comoros are committed;

- create zones equipped with services wherein economic operators will find the entire range of infrastructures needed to facilitate their establishment, including creation of a free trade zone;

- flesh out a communications strategy to better promulgate the reforms;

- undertake actions on behalf of Comorians living abroad and steer their funds in the direction of projects adding to economic development.

\section{b) Agriculture}

The PRGSP has three objectives in the area of agriculture: strengthen the security of the land heritage of the Comoros, support the creation of an environment favorable to development of the sector, and lead a recovery of agricultural and agro-food production.

Highlights of programs and projects implemented in 2011 were:

- commitment by the authorities to ensuring food self-sufficiency; 
- a substantial increase in imports of agricultural foodstuffs, both plant and animal;

- demand driven by population growth;

- weak recovery in exports of cash crops.

Breakdown of priority indicators

\begin{tabular}{|l|r|r|r|}
\hline \multicolumn{1}{|c|}{ Priority indicators } & $\begin{array}{c}\text { 2010 } \\
\text { reference } \\
\text { value }\end{array}$ & 2011 target & $\begin{array}{c}\text { 2011 } \\
\text { performance }\end{array}$ \\
\hline Percentage of registered land parcels & $163,000 \mathrm{ha}$ & $25 \%$ & 0 \\
\hline Growth rate of agricultural production & $10 \%$ & $10 \%$ & $20 \%$ \\
\hline Growth rate of agricultural investment & $5 \%$ & $8 \%$ & $5 \%$ \\
\hline Growth of market garden production & $21 \%$ & $60 \%$ & $60 \%$ \\
\hline Number of catchment areas rehabilitated & $\mathrm{ND}$ & 50 & 1 \\
\hline
\end{tabular}

Source: General Directorate for Agriculture and Livestock

\section{Percentage of registered land}

Agricultural production is confronted with the real landed property problem, and more particularly the problem of the status of the land owner. The percentage of agricultural land currently registered is very small - in the area of 163,000 hectares. In 2011, the state property department recorded no requests for registration of farm land parcels, thereby thwarting the target of 25 percent set in 2011.

The commitment by the authorities to restructure the land tenure system will help quiet tensions and conflicts that undermine the performance and dynamism of village communities. Their actions will have positive effects on rendering farm land more secure and providing people with incentives to take up farming. The communal development process now ongoing will link town councils and NGOs involved in agriculture for the purpose of identifying arable land, and is expected to help in achieving the targets set for the sector. The exorbitant cost of registering land would explain peoples' reticence to register their land holdings. The Forestry Law constitutes a beginning of the solution to the land problem. However, financial resources are being mobilized from development partners such as IFAD (PNDHD_National Program for Sustainable Human Development) to support the security of land holdings, protection, and management of vulnerable sites. Clarifying the agricultural land tenure system will have the effect of establishing high-yield farming.

\section{Growth rate of farm production}

The growth rate of food production posted a result exceeding the threshold aimed at for 2011. Food crops and legumes account for the greatest share of this performance, the result of support in the form of farming inputs and the multiplication of food crop seeds from our partners, especially the IDB and the PNDHD. This suggests an opportunity to establish a national center for seed production, given the fact that the programs are happy to import them. 
We should also note the significant contribution of the value chain project of the United Nations system on Mohéli to increased production of food crops, even though problems related to preservation and commercialization have arisen. The same is true of the HajohoJimilime road corridor project on Anjouan undertaken by PREDIVAC/AFD, a region with substantial farming potential.

\section{Growth rate of agricultural investment}

The growth rate of agricultural investment was flat between 2010 and 2011, and this impelled the national authorities, with the support of technical and financial partners, to envisage various actions aimed at improving the indicator within the framework of the program supporting an environment favorable to agricultural production.

In particular, we note the commitment of Iranian foreign aid to acquire 70 mini-tractors; the development of irrigation systems in the farming zones of Pomoni (Anjouan); the promotion and development of small processing and preserving units for short-term perishable goods (United Nations system); and the establishment of a laboratory for the analysis of food products (FAO), etc.

\section{Growth of legume food crops}

Food crop production increased by 60 percent as forecast in 2011. This was the result of programs for distribution of agricultural seeds to farmers; installation of new irrigation systems in farm lands; programs supported mainly by IDB, IFAD and the UN system.

\section{Number of catchment areas built}

The target of 50 catchment areas set for 2011 is far from being reached. In fact, only a single partner, Iran, has invested in rehabilitating a catchment area in Koua-Mitsamiouli. Financial resources intended for this activity have met with delays in mobilization. Actions envisaged for 2011 are now deferred to 2012, which promises a future intensification of garden produce and legume production.

\section{Sector financing}

\begin{tabular}{|c|c|c|}
\hline Donor & Completed projects & $\begin{array}{c}\text { Amount (KMF } \\
\text { millions) }\end{array}$ \\
\hline Iran & Constructed catchment area & 15 \\
\hline FAO & Analytical laboratory & 4 \\
\hline PREDIVAC/AFD & Support to SNAC & 522 \\
\hline FEM & Irrigated perimeter & 20 \\
\hline IDB & Seeds & 90 \\
\hline IFAD & Seeds & 17 \\
\hline Value chain project/UN system & Sector support & 237 \\
\hline $\begin{array}{ll} & \text { Total } \\
\end{array}$ & & 1,105 \\
\hline
\end{tabular}




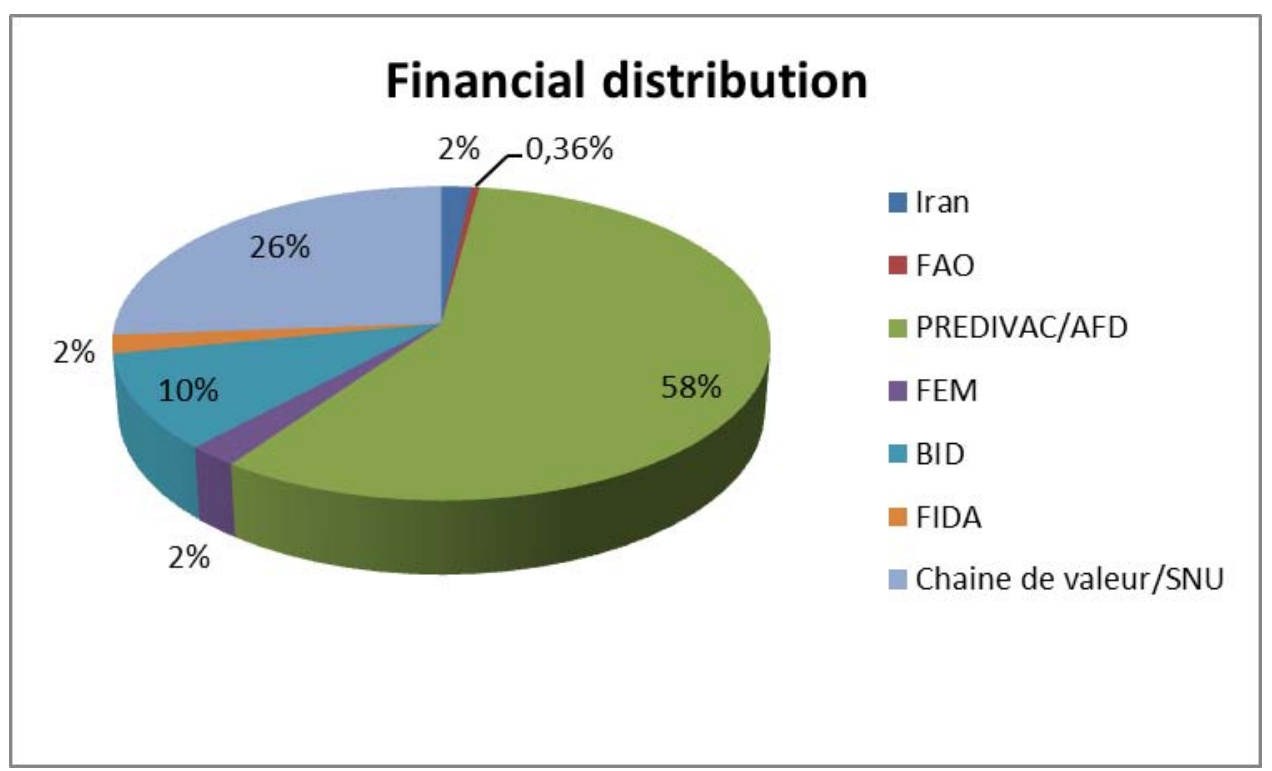

[right column, top to bottom: Iran; FAO; PREDIVAC/AFD; FEM; IDB; IFAD; Value chain project/UN system]

\section{Outlook and recommendations}

As for recommendations, there are good reasons to:

- $\quad$ speed up the process of registering land;

- involve farmer organizations as partners in development of the sector;

- professionalize the sector by incentivizing young persons (current average age of farmers is 56 years) while simultaneously strengthening training of participants;

- underscore crop group plans within the framework of a new agricultural strategy oriented towards exports;

- encourage small- and medium-sized farm operations;

- make the Mwali agricultural school operational;

- establish a monitoring body for partner activities;

- establish a research and analysis unit devoted to agricultural statistics;

- promote inter-island circulation of agricultural products;

- improve the preservation and distribution circuits of products;

- $\quad$ strengthen the capacities for managing programs and projects within the ministry. 


\section{c) Livestock}

With a view to developing cattle rearing, the PRGSP aims to protect animal livestock against exotic infectious diseases and intensify animal production categories.

In 2011, the implementation of programs and projects was characterized by:

- a strong increase in imports of meat products;

- sustained demand for animal protein reflecting ever increasing consumer demand;

- intensive recovery of bovine imports from the sub-region.

\section{Breakdown of priority indicators}

\begin{tabular}{|l|r|r|r|}
\hline \multicolumn{1}{|c|}{ Priority indicators } & $\begin{array}{c}\text { 2010 } \\
\text { reference } \\
\text { value }\end{array}$ & $\begin{array}{c}\text { 2011 } \\
\text { target }\end{array}$ & 2011 performance \\
\hline Rate of livestock vaccination coverage & $25 \%$ & $40 \%$ & $18 \%$ \\
\hline Number of ruminants treated & $\mathrm{NR}$ & 20,000 & $7,500(37.5 \%)$ \\
\hline Number of poultry vaccinated & $25 \%$ & $40 \%$ & $87,301(1,306 \%)$ \\
\hline Rate of poultry vaccination coverage & $25 \%$ & $25 \%$ & $24 \%$ \\
\hline Ruminant mortality rate & $80 \%$ & $\mathrm{NA}$ & $20 \%$ \\
\hline Poultry mortality rate & $30 \%$ & $40 \%$ & $30 \%$ \\
\hline Protein needs covered & $\mathrm{NR}$ & 600 & 297 \\
\hline Inseminations & $\mathrm{NR}$ & 2 & 7 \\
\hline Inseminators trained & $\mathrm{NR}$ & 2 & 3 \\
\hline Number of pilot farms & & $25 \%$ & 800 \\
\hline
\end{tabular}

Source: General Directorate for Agriculture and Livestock

\section{Rate of vaccination coverage of ruminant livestock}

The rate of vaccination coverage of ruminant livestock posted a slight advance, i.e., 18 percent, lower than the threshold of 40 percent targeted; this rate corresponds to 1,095 head vaccinated, out of 59,239 inventoried. This underperformance is explained by the absence of a binding regulation regarding the vaccination protection of animals, as well as the abandonment of the 2011 campaign because of inadequate financial resources. The immediate consequence is that livestock vaccination is carried out at the request of the cattle breeder and at excessive cost, such as in the case of theileriosis, and this despite the support of partners including IFAD and the NGOs Activa/APSA and ACDE.

\section{Number of ruminants treated}

Overall, 7,500 ruminants out of the 20,000 targeted have been treated for blackleg and diseases transmitted by tics, or a completion rate of 37.5 percent. Vaccination against blackleg involved 1,095 head out of 15,000 targeted, for a rate of 7.3 percent. Cattle breeders did not make requests to the programs for vaccination services in the case of diseases transmitted by tics. The low completion rate is the result of the excessive cost of the vaccines and the lack of financial support for the livestock breeders. 


\section{Rate of vaccination coverage of poultry}

The poultry vaccination rate is satisfactory, showing progress from 25 percent in 2010 to 87.06 percent in 2011 . The rate is 78.16 percent on Ngazidja, 89.48 percent on Anjouan, and 95.22 percent on Mohéli. Credit for this achievement goes to the exceptional campaign initiated by VACNADA (EU), whose activities also encompassed local poultry.

\section{Mortality rates for ruminants and poultry}

The mortality rates for ruminants and poultry continue to depend on efforts made in vaccinating. With respect to ruminants, the 24 percent rate recorded in 2011 (compared to 25 percent in 2010) reflects the low rate of vaccination recorded. The rate of 20 percent recorded for poultry (compared to 80 percent in 2010) reflects the government's efforts to protect poultry.

\section{Protein needs covered}

Protein coverage of 30 percent accounts for the massive imports of poultry giblets and meat products as well as bovids. In a move to staunch this hemorrhaging of our trade balance, the government initiated a feasibility study for creating an industrial livestock rearing unit; the Reunion Island general council has indicated an interest in supporting such a program. The value chain project on Mohéli and the support of the French Development Agency to Ndzouani are currently working on improving this coverage of protein needs.

\section{Insemination undertaken}

For the purpose of improving milk production, a program has been implemented to introduce cross-bred cows. Out of 600 cases targeted, a total of 297 cows were inseminated, including 90 percent with the support of IFAD, a modest performance explained by a lack of sufficient specialized human resources, despite the interest shown by the livestock breeders. As a consequence, the government is now directing the support from development partners to training specialized technicians, in order to meet more fully the needs expressed.

\section{Inseminators trained}

The authorities have anticipated the interest that livestock breeders might show in insemination. This explains the training of 25 agents, a number clearly exceeding the target of 2 trainers contemplated for 2011. This initiative will improve the number of inseminations undertaken, thereby indicating the government's determination to intensify milk production.

\section{Number of pilot farms}

With the objective of experimenting with insemination as a means of introducing crossbred species, the government initially envisaged establishing two pilot farms, which plan was clearly exceeded by establishment of more than 3 private farms and 2 associated farms financed by the UN system. It should be noted that in addition to the partners, some 
local promoters have made financial contributions to this effort with a view to intensifying the practice of insemination.

\section{Sector financing}

\begin{tabular}{|l|l|r|}
\hline \multicolumn{1}{|c|}{ Donor } & \multicolumn{1}{|c|}{ Type of involvement } & \multicolumn{1}{c|}{$\begin{array}{c}\text { Contribution } \\
\text { (KMF } \\
\text { millions) }\end{array}$} \\
\hline FIDA & Vaccination & 5 \\
\hline VACNADA (EU) & Vaccination & 32 \\
\hline PNDHD/UNDP & Vaccination & 11.09 \\
\hline FEM & Pilot farm & 25 \\
\hline $\begin{array}{l}\text { Co-development/French Development } \\
\text { Agency }\end{array}$ & Material support & 24 \\
\hline Local partners & Pilot farms & 95 \\
\hline Value chain project/UN system & Poultry raising & $\mathbf{2 0 2 . 0 9}$ \\
\hline
\end{tabular}

Source: General Directorate for Agriculture and Livestock

\section{Financial distribution}

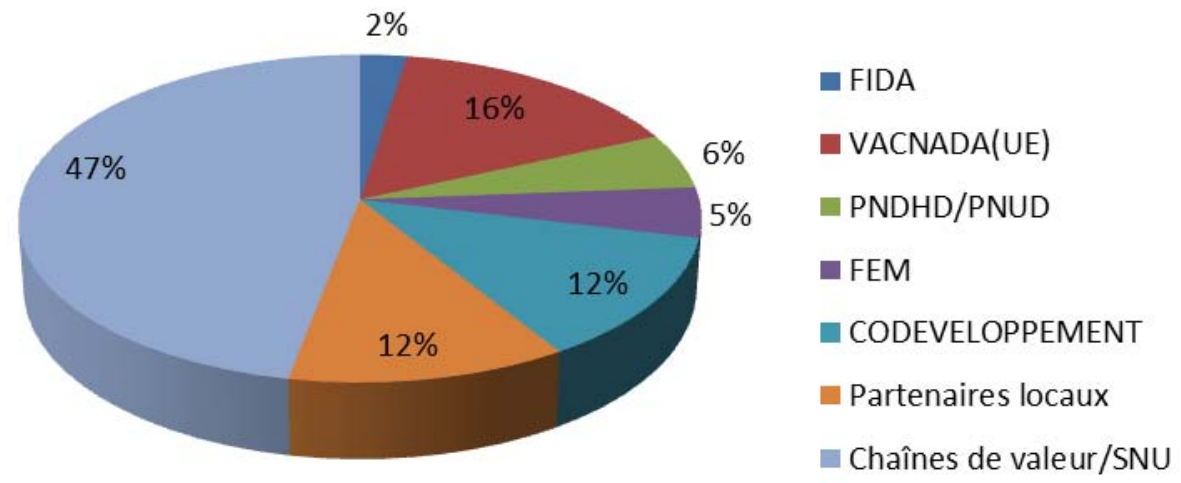

[right column, top to bottom: FIDA; VACNADA (EU); PNDHD/UNDP; FEM; Co-development; Local partners; Value chain project/UN system]

\section{Outlook and recommendations}

The chief recommendations are the following:

- draw up a medium-term policy to cover our protein needs as concerns poultry giblets;

- $\quad$ pass legislation to protect our livestock; 
- contemplate operating an industrial poultry raising facility;

- create the conditions for recovery of the bovid production line;

- prioritize cross-breeding of cows for purposes of milk production;

- explore the paths leading to an industrial breeding unit;

- strengthen animal sanitation conditions at the frontiers.

\section{d) Fishing}

For purposes of developing fishing, the PRGSP seeks to create an environment favorable to the harmonious development of the sector, developing a system for preserving, processing, and marketing seafood products.

Highlights of programs and projects implemented in 2011 include:

- review of fishing agreements with the European Union;

- Qatar's determination to develop the sector;

- localization of fish species far from the coasts and traditional fishing zones;

- agreements on the boundaries of our territorial waters;

- explosion of seafood prices.

\section{Breakdown of priority indicators}

\begin{tabular}{|l|r|r|r|}
\hline \multicolumn{1}{|c|}{ Priority indicators } & 2010 value & 2011 target & 2011 performance \\
\hline Growth rate of seafood products & $0.02 \%$ & $0.07 \%$ & $0.02 \%$ \\
\hline Growth rate of the fishing sector & $1 \%$ & $3 \%$ & $3 \%$ \\
\hline & & & $\begin{array}{r}\text { Available statistics } \\
\text { show a slight } \\
\text { exceeding of this } \\
\text { target }\end{array}$ \\
Growth rate of investments & $5 \%$ & $10 \%$ & 12 \\
\hline DCPs in force & $\mathrm{NA}$ & 25 & 24 \\
\hline Advanced technicians trained & $\mathrm{NA}$ & 10 & 19 \\
\hline $\begin{array}{l}\text { Professional training instructors } \\
\text { trained }\end{array}$ & $\mathrm{NA}$ & 20 & $40 \%$ \\
\hline Motorized vessels & $30 \%$ & $40 \%$ & $0.05 \%$ \\
\hline Losses after catch & $0.05 \%$ & $0.05 \%$ & \\
\hline
\end{tabular}

Source: General Directorate of Fisheries

The growth rate of the fishing sector remained unchanged at 3 percent between 2010 and 2011. Climate changes contributed to that state of affairs, as fishing catches moved outside 
the usual fishing zones, thereafter necessitating the use of motorized boats with large storage capacities.

Despite reaching the target for percentage post-catch loss, the lack of sufficient storage capacity constitutes an impediment to intensification of activities, which explains the immobile growth rate.

The sole fishery enterprise is confronting difficulties cause by high operating costs, and in particular, the rise in the prices of petroleum products. Nevertheless, only the modernization of the sector, with the introduction of new fishing techniques combined with fleets able to navigate on the high seas, is able to impact the rate of production. In this regard, Qatar's commitment to support the efforts of the authorities in the sector to access the export market will have a considerable impact on fishing production and on our economy.

\section{Growth rate of seafood products}

With reference to a target of 0.07 percent for 2011, the growth rate remained unchanged between 2010 and 2011 at 0.02 percent. The causes of that stagnation are identical to the cause of sectoral growth stagnation.

\section{Growth rate of investments}

Sector specialists would all agree that the growth rate of investments in the sector has exceeded the target of 10 percent, with the start of construction on the fish factory supported by the Qatar project. The various accomplishments regarding fishing fleets, outboard motors, construction of small-scale piers, acquisition of cold rooms, etc. are such as contribute to achieving the target set.

\section{Training sessions completed}

Building the capacities of managers and agents in the fishing sector is a response to objectives of modernizing the sector. Various kinds of training are offered by the National Fishing School in Mirontsy-Anjouan, providing 6 training modules while the target was 5, 19 managers trained (out of a targeted figure of 20), not counting the 42 fishing technicians trained within the framework of the Qatari project, including 11 agents in Sri Lanka.

All these actions will contribute to implementing a modern strategy.

\section{Number of motorized vessels}

The authorities' determination to support independent fishermen enabled motorizing of 40 percent of fishing boats in 2011, compared to 30 percent in 2010. Credit is due to the policy of waving fees and customs duties on fishing boats and outboard motors begun with the Budget Law, and having the effect of lowering the cost of acquiring boats by 20 percent. However, special mention should be made of the acquisition of large-scale fishing fleets based on the assumption of a modernized sector. 


\section{Percentage of post-catch losses}

The rate of post-catch losses remained unchanged at 0.05 percent between 2010 and 2011 . Preserving and marketing problems thus penalize the efforts of fishermen. Some development partners support the sector, with a goal of boosting production, including Japan, which has rehabilitated refrigeration equipment and ice making equipment, while Qatar supported intensified production.

\section{Sector financing}

\begin{tabular}{|l|l|r|}
\hline \multicolumn{1}{|c|}{ Donor } & \multicolumn{1}{|c|}{ Activity } & \multicolumn{1}{c|}{$\begin{array}{c}\text { Amount (KMF } \\
\text { millions) }\end{array}$} \\
\hline European Union & Control and surveillance & 118.2 \\
\hline $\begin{array}{l}\text { Indian Ocean Commission/ } \\
\text { World Bank }\end{array}$ & Fishing development & 23 \\
\hline PNDHD & Country cooperation document & 1.723 \\
\hline Qatar & Construction (fishing project) & 320 \\
\hline European Union & Statistics & 28 \\
\hline JICA & Rehabilitation of fishing school & 470 \\
\hline \multicolumn{2}{r|}{} & $\mathbf{1 9 7}$ \\
\hline
\end{tabular}

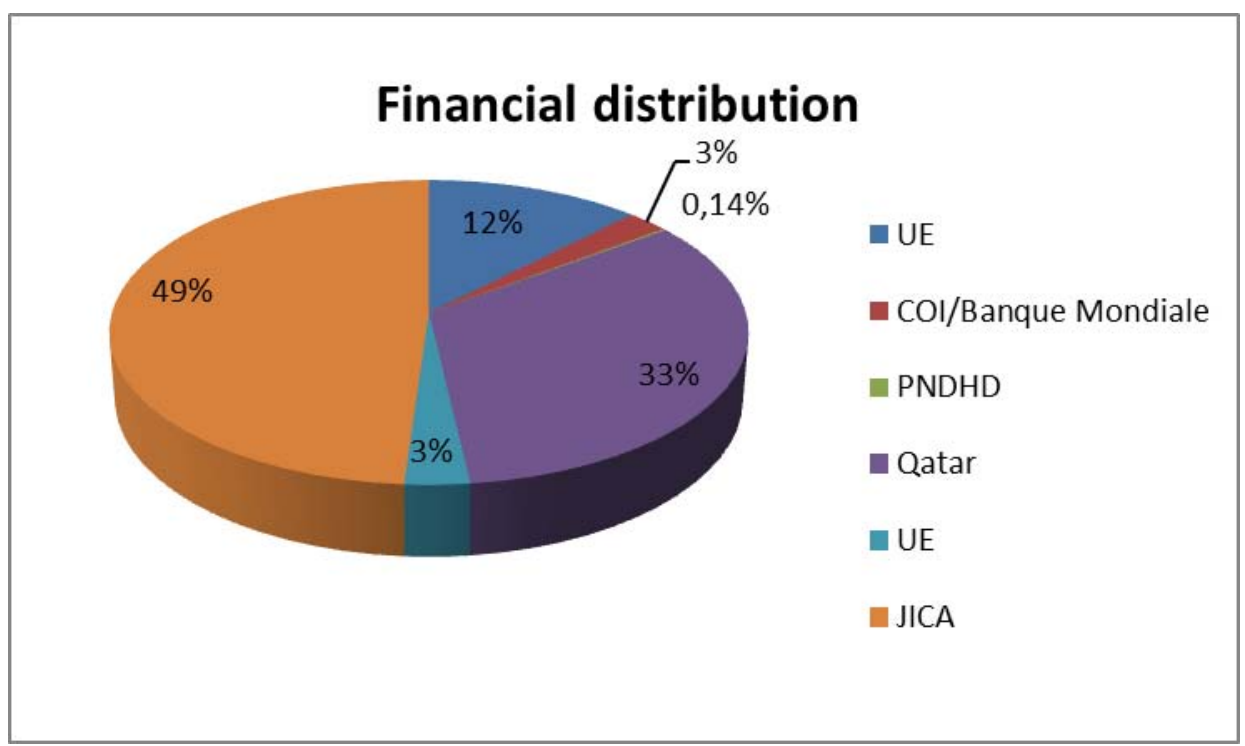

[right column, top to bottom: EU; IOC/World Bank; PNDHD; Qatar; EU; JICA]

\section{Outlook and recommendations}

The fishing sector must recast its strategy and devote itself to economic development, becoming a rallying point for job creation. An operation oriented to the export market offers possibilities for job creation and added value. The handling and processing unit that will emerge from the new Qatari unit will require an intensive work force and will have a real impact on the contribution of the sector to GDP. Moreover, since the jobs will be rather intended for women, the project will impact the autonomy of women.

The sectoral recommendations are as follows:

- take the lead in sector changes by drawing up a human resources training plan; 
- encourage construction of storage and preservation units in the targeted zones;

- initiate a policy of modernizing the fishing sector;

- speed up the construction of piers and small-scale fishing ports;

- set up a body to monitor partner activities;

- take advantage of our membership in integration groups;

- take advantage of the definition of the limits of our maritime borders.

\section{e) Tourism}

In the context of the PRGSP, the tourism sector has set development of the sector as its objective.

In 2011, the implementation of programs and projects was characterized by:

- construction of the National Office of Tourism;

- passage of a law on tourism.

\section{Breakdown of priority indicators}

\begin{tabular}{|c|c|c|}
\hline Results indicator & 2011 target & $\begin{array}{c}2011 \\
\text { Performance/trend }\end{array}$ \\
\hline Tourist arrivals & 20,000 & 15,000 \\
\hline Beds available & 700 & 1,026 \\
\hline Number of persons trained & 100 & 175 \\
\hline Number of major cultural events organized & 3 & 2 \\
\hline
\end{tabular}

Source: General Tourism Directorate

Despite the lack of statistics for 2011 on tourist arrivals, and despite the lack of a specific event able to influence the flow of arrivals at the borders, it is estimated that the trend in tourist arrivals would be between 15,000 and 16,000 persons.

In fact, growth fell from 23.04 percent in 2010 to a level of 3.30 percent in 2011, an underperformance explicable by the transportation sector, with its elevated cost for the Comoros destination, combined with the absence, irregularity, and uncertainty of direct flights to the major touristic markets, and poor connections between flights. The same is true of the transportation service between islands, characterized by irregular flights and ever more costly services in general. The high cost of visas for stays is another factor discouraging tourists passing through neighboring countries from adding the Comoros as a destination on their trips.

Tourist hosting capacity has improved, meanwhile, with 282 new beds added through the development of small-scale hosting, with a total of 1,026 beds available in 2011, compared to 472 beds in 2009 . 
Having begun in March 2011, construction of the National Tourism Office was completed in December 2011. Clearly the Office could be operational in 2012. This project is the result of cooperation with the People's Republic of China and would constitute an excellent tool for our administration's promoting of tourism.

Because it is believed that tourism must be one of the Comoros' engines of development, training related to the sector's capacities have been undertaken and 175 persons have benefited from this training. IUT, CUFOP and UCCIA offer initial and ongoing training, of short duration and sometimes modular. The APROJEC project of ILO has supported these initiatives.

Two major events have been organized:

- the Medina festival, held annually in Mutsamudu, Anjouan;

- Briskly, a traditional dancing contest, held annually in Mbeni, Ngazidja.

These artistic and cultural events stir enthusiasm in visiting tourists come to appreciate our cultural diversity.

On Ndzouani, French foreign assistance has supported the restoration of historic sites, including the fort and citadel of Mutsamudu. UNESCO has also rehabilitated historic monuments on Ngazidja. These completed projects are going to have an impact on the inflow of tourists into the Comoros.

\section{Sector financing}

\begin{tabular}{|c|c|c|}
\hline Donor & Activity & Amount (KMF millions) \\
\hline People's Republic of China & Real estate infrastructure & 400 \\
\hline Union of Comoros & Logistical support & 30.7 \\
\hline UNDP (ILO) & Training & 13.75 \\
\hline Total & & 444.45 \\
\hline
\end{tabular}

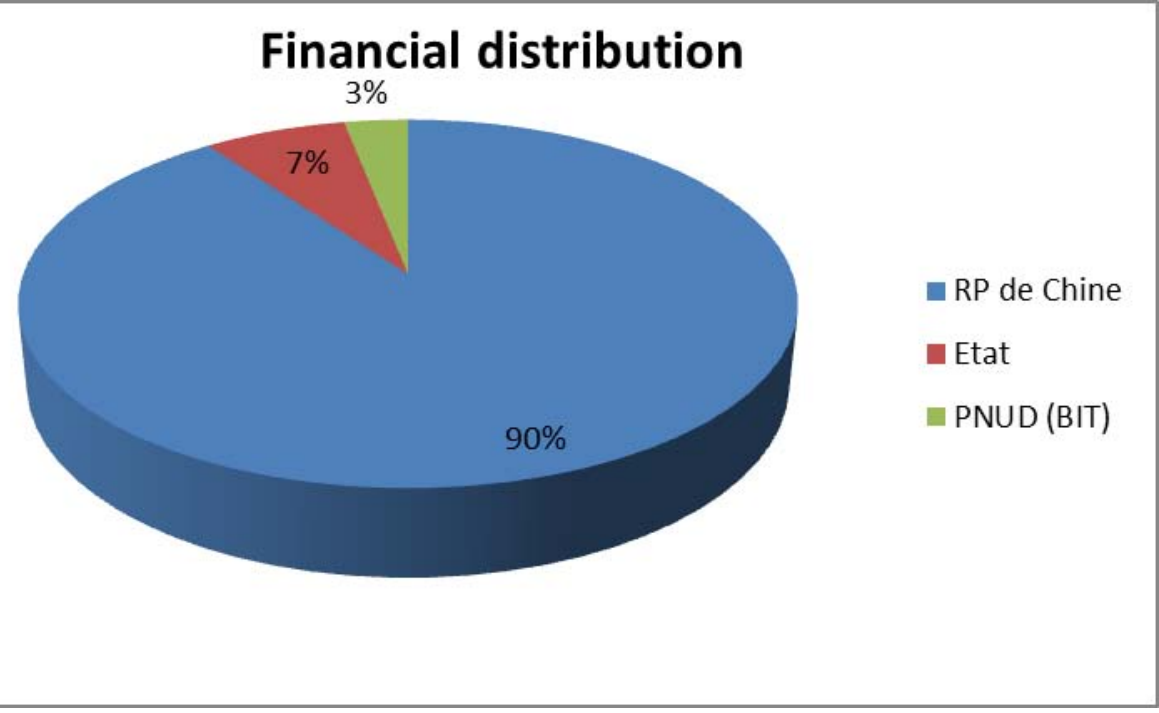

[right column, top to bottom: People's Republic of China; Union of Comoros; UNDP (ILO)] 
Based on the observation that more than 50 percent of touristic visits are made by friends and family, it is crucial to develop services targeting them, for instance in a customer satisfaction inquiry to serve as a guide to actions and strategies in response. Comoros must target its touristic clientele, with a presence in the world's major trade fairs and exhibitions, and with a view to mounting a genuine promotion of the sector.

Whence the following recommendations:

- $\quad$ set up an information desk on tourism in the airports;

- mobilize the needed resources to mount programs, with particular efforts going to the internal market;

- take advantage of tourist arrivals in the sub-region;

- revitalize the site on tourism in the Comoros;

- develop cultural activities in support of tourism promotion;

- establish a partnership with air transportation companies offering organized visits and promotional rates for visitors;

- revive both island and inter-island tourism;

- mount annual promotional activities;

- revive the cultural festivities of our cultural heritage.

\section{Core strategy 3: strengthen governance and social cohesion}

This core strategy involves implementing programs and projects aimed at strengthening good governance and social cohesion by forging democratic and administrative institutions at the Union and island levels. Specifically, it is a matter of:

$\checkmark$ Promoting good governance, social cohesion, solidarity and peace-building

$\checkmark$ Improving the legal framework, stepping up efforts to combat corruption, and boosting transparency and governance

$\checkmark$ Strengthening justice system capabilities

$\checkmark$ Fighting terrorism and international crime and strengthening civil security. Program implementation focused on:

Adoption of Law $N^{\circ} 11-028 / A U$ of $12 / 23 / 11$ on the National Commission on Human Rights and Freedoms. 
Adoption of Law $\mathrm{N}^{\circ} 11-017 / \mathrm{AU}$ of $12 / 13 / 11$ on the rights of disabled persons.

Adoption of Law $\mathrm{N}^{\circ} 11-006 / \mathrm{AU}$ of May 2, 2011 concerning the communal organization of the Union of Comoros and Law $\mathrm{N}^{\circ} 11-005 / \mathrm{AU}$ of 4/7/11 on decentralization.

Analysis of priority indicators

\begin{tabular}{|l|c|c|}
\hline Indicators & Target for 2011 & Achieved in 2011 \\
\hline Conflict potential and dynamics & Studies & Studies carried out \\
\hline Conflict settlement mechanisms & Studies & Studies carried out \\
\hline $\begin{array}{l}\text { Job creation through vocational } \\
\text { training }\end{array}$ & 150 & 280 \\
\hline Number of laws voted on & 10 & 24 \\
\hline $\begin{array}{l}\text { Number of international } \\
\text { conventions ratified }\end{array}$ & 5 & 5 \\
\hline $\begin{array}{l}\text { Number of certified audits and } \\
\text { reports }\end{array}$ & 3 & 10 \\
\hline $\begin{array}{l}\text { Number of judicial bodies } \\
\text { established }\end{array}$ & & 1 \\
\hline Installation of the Supreme Court & Up and running & Up and running \\
\hline Number of prisons rehabilitated & 3 & 1 \\
\hline $\begin{array}{l}\text { Number of courthouses } \\
\text { built/rehabilitated }\end{array}$ & 3 & 3 \\
\hline Source: Depard (Direction Generale of & & \\
\hline
\end{tabular}

Source: Department (Direction Générale) of Solidarity and Gender Promotion

- Conflict potential and dynamics and settlement mechanisms

Studies have been carried out by the NGO CAP on social prejudices, forms of discrimination, citizenship, and women's and youth expectations with respect to social cohesion.

Other initiatives were undertaken, especially in connection with the UNDP's Peace Building Fund Program (PBF). We would mention the establishment of 16 peace committees and the organization of nine exchange meetings among their members. Other peace-building activities included the organization of a training course on conflict prevention and management techniques, an exchange of experiences trip to Burundi for two officials, and the organization of reconciliation meetings between ex-FGAs and their victims.

At the University of the Comoros, a unit was established to do research into social cohesion, with a view to raising awareness among young people of the need to safeguard it.

Finally, the biometric voter registration project supported by our partners will help promote the proper conduct of elections, a permanent source of conflicts during the electoral process. This achievement would strengthen the actions of election management and oversight bodies. It is worth pointing out that the targets envisaged for this indicator have almost been reached thanks to our partners' efforts. 


\section{- Job creation through vocational training}

The projection that 100 people would be trained was exceeded by far. That is to be attributed to actions undertaken as part of the ILO's APROJEC project, which supported training and incorporation into the labor market for 280 youths and women in the agricultural sector, and training for 25 women in the hotel business and 30 youths in car repair.

The IMDAD Committee (IRAN) trained more than 1,000 youths in a range of activities, such as embroidery, joinery, information technology, decoration, and so on. However, jobs and outlets still have to be found for all those who have received training.

\section{- Laws enacted and conventions ratified}

Projections with respect to conventions involving alignment with international standards were met. In fact, Parliament authorized the Head of State to ratify five conventions related to strengthening governance (the rights of disabled persons; protection of cultural diversity; countering terrorism in all its forms and manifestations; prohibition of the development, production, stockpiling, and use of chemical weapons, and on their destruction).

As for laws, 24 laws were voted on by Parliament in 2011 (compared to the target of 10).

\section{- Number of certified audits and reports}

With a view to enhancing transparency, 10 audits were conducted of public enterprises, the three main health facilities, and of budget execution in the islands. Those audits helped contain public expenditure and had an impact on fiscal balances.

The establishment of the National Commission to Combat Corruption appears to be strengthening economic good governance, with 56 cases being investigated by this institution, of which six have been forwarded to the judiciary.

However, much remains to be done in the area of transparency, particularly with regard to the establishment of deterrents.

\section{- Revitalization of the administration}

Several achievements enabled us to improve the performance of our public administration in 2011. They included the training provided, with the support of the European Union, to administration officials in operational and strategic programming and the training of local government representative and officials with UN and EU support. The (World Bank) Support for Economic Good Governance (AGBE) project helped the civil service authorities restructure our public administration by conducting a census of government officials, extending the integrated personnel management system to all three islands (GISE), and updating and validating professional category staff. All these actions should have a real impact on the effectiveness of our administration.

\section{- Share of the budget allocated to local government}

The share allocated to local governments is still negligible. The Moroni district (commune) receives a government grant through the "Unique Administrative Royalty" (RAU). In Anjouan, the districts receive compensation taxes and the Island budget pays for some officials' wages. Given the nonexistence of regulations on local taxation, local governments make their own arrangements for day-to-day management. 
- Number of judicial bodies established

The goal of three bodies set for 2011 was met, with the appointment of juvenile court judges at the lower court level. Moreover, in a community justice context, 32 new qadis (Muslim judges) were appointed.

The Supreme Court was also established along with the court of cassation and administrative section.

These achievements are in line with the goal of establishing a functional judicial system, by completing the range of lower courts, installing the Supreme Court and forming the Higher Council of the Judiciary (conseil supérieur de la magistrature).

- Rehabilitation of the prisons

The Koki prison in Anjouan has been rehabilitated and a juvenile detention center is being built. Achievements are below target, because scant financial resources were mobilized for this project. The Moroni prison was rehabilitated by the French Red Cross.

- Courtrooms rehabilitated and/or built

The target was met by constructing the Mohéli and Anjouan law courts and rehabilitating the Ngazidja facilities. The National Police School was built in Ndzouani and the police station rehabilitated in Ngazidja.

However, an effort still needs to be made to provide the equipment needed for these facilities.

\section{Financing}

\begin{tabular}{|l|l|lr|}
\hline Donors and creditors & Contributions to: & $\begin{array}{l}\text { Amount (in millions of } \\
\text { KMF) }\end{array}$ \\
\hline UN & Real estate infrastructure & 2860 \\
\hline Government & Logistical support & 159 \\
\hline EU & Training & 2230 \\
\hline World Bank & Administrative reforms & 77 \\
\hline Iran & Real estate infrastructure & 25 \\
\hline Total & & $\mathbf{5 3 0 0}$ \\
\hline
\end{tabular}




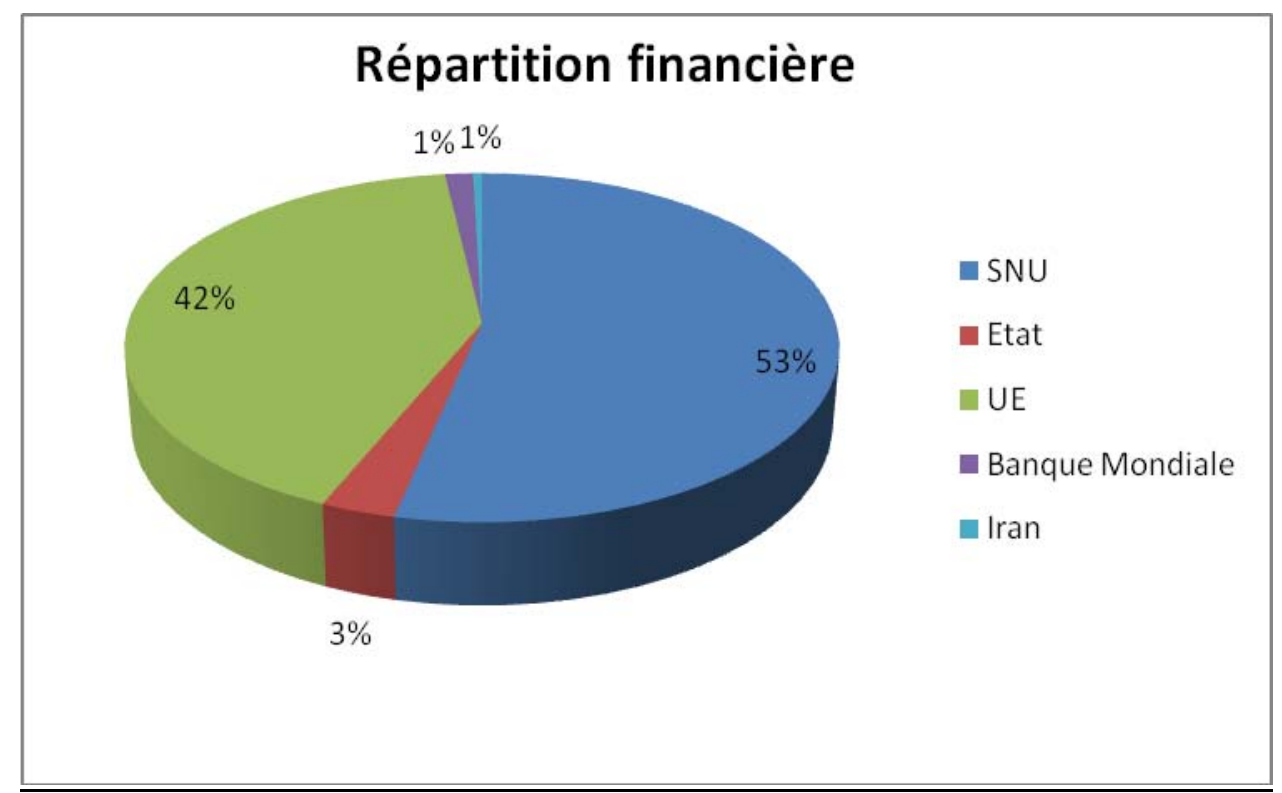

[Key: Distribution of Funding. Dark Blue: United Nations. Red: Government. Green: EU. Purple: World Bank. Light blue: Iran

\section{Outlook and recommendations}

Recommendations:

$\checkmark$ Engage in advocacy with the Government and financial partners for a settlement of the situation of the ex -FGAs in order to bring about complete national stability

$\checkmark$ Establish a permanent, independent institutional framework for ensuring transparency in electoral processes

$\checkmark$ Put in place a new legal framework to govern the conduct of political parties during electoral processes

$\checkmark$ Equip the National Police School in Anjouan (with dormitories, teaching materials, educational tools and sports equipment)

$\checkmark$ Provide materials, uniforms and protective gear for the police stations on the three islands

$\checkmark$ Provide the police precincts with surveillance equipment for sensitive areas

$\checkmark$ Establish Rules of Procedure for Civil Service Management, including arrangements for transferring and allocating budget items at the islandsUnion level

$\checkmark$ Ensure that the consultative bodies of the High Authority for the Civil Service (FOP) function effectively

$\checkmark$ Organize training courses tailored to the administration's needs

$\checkmark$ Establish statistics departments in the government's administrative units 
$\checkmark$ Computerize information systems regarding court rulings and legal instruments

$\checkmark$ Give users access to judicial system data

$\checkmark$ Establish legal libraries in the law courts

$\checkmark$ Establish local community judges in the regions as part of the decentralization effort

$\checkmark \quad$ Put in place a guidance and training system for youth enrolled at school as well as for out-of-school youth

$\checkmark$ Establish a pension system for all Comorians, regardless of the sector they work in.

\section{Core strategy 4: Improve the health status of the general public}

This core strategy seeks to improve the general public's access to quality health care, especially for the most vulnerable groups and the rural population. It accords top priority to addressing anemia and to improving all the components of the health care system.

Specifically, it is a matter of:

$\checkmark$ Combating malaria and priority diseases

$\checkmark$ Integrated development of sexual and reproductive health

$\checkmark$ Fighting HIV/AIDS and sexually transmitted diseases

Making all facets of the health system more effective and efficient.

In 2011, sectoral program and project implementation focused on:

$\checkmark$ The adoption and promulgation of Law $\mathrm{N}^{\circ} 11-001 / \mathrm{AU}$ of $3 / 26 / 11$ on the public health code

$\checkmark$ Adoption of Law $N^{\circ} 11-002 / A U$ of $3 / 27 / 11$ to combat tobacco consumption.

$\checkmark$ Adoption of Law $\mathrm{N}^{\circ} 11-004$ of 3/26/11 on regulating mutual health insurance associations

$\checkmark$ Conducting a malaria indicators survey (MIS)

$\checkmark$ Conducting the STEP Wise survey on risk factors for noncommunicable diseases

$\checkmark$ Mass distribution of insecticide-treated mosquito nets 
$\checkmark$ Preparation and validation of a 2011-2015 strategic plan to combat tuberculosis and leprosy

$\checkmark$ Revision of the 2010-2014 National Human Resources for Health Development Plan

$\checkmark$ Implementation of the Hombo and Fomboni contingency hospital plans.

$\checkmark$ Preparation and validation of the 2010-2015 Family Planning Advocacy Strategy

$\checkmark$ Preparation and validation of the National Strategy paper for Preventing and Fighting Cancer in the Union of Comoros

$\checkmark$ Preparation of the pharmaceutical profile

$\checkmark \quad$ Validation of national food and nutrition policy

$\checkmark$ The rehabilitation and equipping of certain health facilities

$\checkmark$ The establishment of management bodies in hospitals

$\checkmark$ Care for People Living with HIV

Production of teachers' guidelines and schoolbooks for teaching about HIV in schools.

\section{Analysis of priority indicators}

\section{Combating malaria:}

\begin{tabular}{|c|c|c|}
\hline Performance indicators & Benchmark & Achieved in 2011 \\
\hline Malaria prevalence rates & & 8.9 \\
\hline $\begin{array}{l}\text { Percentage of malaria cases } \\
\text { among persons visiting a doctor's } \\
\text { office }\end{array}$ & $50 \%(2004)$ & $36 \%$ \\
\hline $\begin{array}{l}\text { Tuberculosis prevalence rate per } \\
100,000\end{array}$ & $\begin{array}{r}60 / 100,000 \text { inhabitants } \\
(1985)\end{array}$ & $\begin{array}{l}37 / 100,000 \\
\text { inhabitants }\end{array}$ \\
\hline Tuberculosis cure rate & $90 \%(2009)$ & $94 \%$ \\
\hline $\begin{array}{l}\text { Immunization coverage by } \\
\text { antigen: }\end{array}$ & $\begin{array}{r}\text { BCG : 80\%(2009) } \\
\text { DTC-hepB-Hib } 1: 89 \% \\
(2009) \\
\text { DTC-hepB-Hib } 3: 83 \% \\
(2009) \\
\text { VAR (anti-measles) : } \\
(77 \%), 2008\end{array}$ & $\begin{array}{r}\text { BCG : } 88 \% \\
\text { DTC-hepB-Hib } 1: \\
92 ; 1 \\
\text { DTC-hepB-Hib } 3: \\
86,7 \\
\text { VAR: } 78 \\
\text { VAT2+ (anti- } \\
\text { tetanus) }: 22,8\end{array}$ \\
\hline
\end{tabular}

Source: National Health Department 
In the Union of Comoros, malaria is the leading cause of morbidity and mortality. The prevalence rate is estimated to be 8.9 percent (MIS 2011). The share of malaria cases in consultations fell from 50 percent in 2004 to 36 percent in 2011. It should be stressed that while morbidity remains high, mortality is notably low (53 deaths reported in 2010). This low mortality rate appears to be related to the availability of free treatment for uncomplicated malaria cases and to the massive malaria treatment campaign conducted in Mohéli between 2008 and 2010.

For tuberculosis, the monitoring indicators are in line with the international standards set by the WHO ( 85 percent cure rate), thanks in particular to the constant support of the Damien Foundation and the WHO.

Between 1985 and 2011, the prevalence rate for tuberculosis fell from 60 to 37 cases per 100,000 inhabitants, a 40 percent decline. The cure rate is satisfactory, having risen from 90 percent in 2009 to 94 percent in 2011. This indicates that the treatment provided is exemplary, bacteriological monitoring is excellent, multi-drug resistance is under control, and the Directly Observed Treatment Short Course Strategy (DOTS) is rigorously followed.

A major step in the struggle against tuberculosis was taken in 2011, namely the drafting and validating of the 2011-2015 Strategic Plan to Stop TB.

In the struggle against vaccine-preventable diseases, there was a noticeable improvement in immunization coverage by antigen. In 2011, immunization coverage for the various antigens was 88 percent for BCG, 92.1 percent for DTC/Hep/Hib1, 86,7 percent for DTC/Heb/Hib3, 78 percent for measles, and 22.8 percent for VAT2+ (anti-tetanus vaccination). This improvement owes much to the support received from the Global Alliance for Vaccines and Immunization (GAVI), UNICEF, the Japan International Cooperation Agency (JICA) and the WHO for the installation of new equipment and facilities, training, validation of the Complete Multi-annual Plan (PPAC) of the Extended Vaccination Program (PEV), the installation of vaccine storage facilities, and the introduction of management tools for vaccination services.

\section{Integrated development of sexual and reproductive health:}

\begin{tabular}{|l|l|l|}
\hline \multicolumn{1}{|c|}{ Performance indicators } & \multicolumn{1}{|c|}{ Benchmark } & Achieved in 2011 \\
\hline Maternal mortality rate & $\begin{array}{l}380 \text { deaths per } \\
100,000 \text { live births } \\
{[\mathrm{LB}](2003)}\end{array}$ & \\
\hline $\begin{array}{l}\text { Prenatal care coverage rate } \\
\text { (women who had at least one check up) }\end{array}$ & $45 \%(2010)$ & $53 \%$ \\
\hline Percentage of births in health facilities & $49 \%(2010)$ & $56 \%$ \\
\hline Infant mortality rate & $49 / 1000 \mathrm{LB}(2007)$ & \\
\hline Infant and child mortality rate & $66 / 1000 \mathrm{LB}(2007)$ & \\
\hline Sorce Hth & & \\
\hline
\end{tabular}

Source: Health Department

No recent data are available for analyzing changes in contraceptive prevalence rates. However, the information that does exist suggests that the rate remains fairly low and is changing only slowly. In that context, the United Nations Population Fund (UNFPA) has provided considerable support for the drafting of the paper advocating family planning, 
the provision of data carriers for health facilities, the production of information material, the organization of awareness-raising sessions, and the provision of contraceptives. In 2003, the maternal mortality rate was 380 per 100,000 live births (General Population and Housing Census, RGPH). In 2010, 17 maternal deaths in hospital facilities were reported, compared to 24 in 2011. In that connection, some mother and child health indicators improved, including the percentage of births in hospitals, which increased from 49 in 2010 to 56 percent in 2011. The share of Cesarean births rose from 5 percent in 2010 to 6 percent in 2011 and pre-natal care coverage rate (at least one consultation, PNC1) rose from 45 percent in 2010 to 53 percent in 2011. Despite that, it should be noted that not enough pregnant women attend a first prenatal consultation.

In addition, infant and child mortality data are not available for 2001. The data available suggest greater likelihood of reaching Millennium Development Goal 4 on the reduction of the mortality rate for children under five years of age. The infant and child mortality rate fell from 112.2 per thousand in 2003 to 66 per thousand in 2007, while the infant mortality rate declined from 79.3 per thousand in 2003 to 49 per thousand in 2007.

\section{Combating HIV/AIDS and transmittable infections:}

\begin{tabular}{|l|c|c|}
\hline Performance indicators & Benchmark & Achieved in 2011 \\
\hline Prevalence of HIV/AIDS & $0.025(2003)$ & \\
\hline
\end{tabular}

Source: Health Department

Despite the slowdown in the HIV/AIDS epidemic, this infection is still one of the major global and national public health problems. The country has a low prevalence rate estimated at 0.025 (RGPH). Screening conducted in 2011 showed that 151 people were living with HIV/AIDS.

Major actions were undertaken in 2011, with support from the Global Fund, UNAIDS, and $\mathrm{WHO}$, to prevent seroprevalence increasing. They included the provision of antiretroviral (ARV) and Opportunistic Infection (OI) drugs and rapid tests for HIV, hepatitis B and C (HBS, HCV), and syphilis (rapid plasma regain, RPR), sensitization of the population, and the preparation of schoolbooks and guides for teaching about HIV/AIDS in schools.

Making all facets of the health system more effective and efficient:

\begin{tabular}{|l|c|c|}
\hline $\begin{array}{l}\text { Performance } \\
\text { indicators }\end{array}$ & Benchmark & Achieved in 2011 \\
\hline $\begin{array}{l}\text { Health facility } \\
\text { attendance rate }\end{array}$ & $10.25 \%(2009)$ & \\
\hline
\end{tabular}

Source: Health Department

The health facility attendance rate is very low (10.25 percent in 2009). No information is currently provided on this indicator, but, judging by observed trends, it remains low. Several actions were carried out in 2011 to make all facets of the health system more effective and efficient. They included installing management bodies in hospitals, the drafting of hospital regulations, the strengthening of technical platforms in District Health 
Centers and Health Posts, technical and training support for the pharmaceutical system, the promotion of financing mechanisms by establishing mutual health insurance companies, strengthening the qualified human resources capacity of health facilities, especially by training specialized physicians, supporting training in public health, reinforcing the health care information system, and, finally, the building, rehabilitation, expansion, and equipping of a number of health facilities.

\section{Financing}

The sector is financed through a variety of mechanisms including Government allocations and contributions from international development partners and international NGOs in the amount of [KMF] 5,226,922,528 in 2011.

The following Table lists financial contributions in 2011.

\begin{tabular}{|l|r|}
\hline \multicolumn{1}{|c|}{ Sources of financing } & \multicolumn{1}{c|}{ Amount } \\
\hline GOVERNMENT & 853800000 \\
\hline Government sub-total & \\
\hline DEVELOPMENT PARTNERS & 733745310 \\
\hline WHO & 415308800 \\
\hline UNICEF & 243581527 \\
\hline UNFPA & 1423077528 \\
\hline $\begin{array}{l}\text { AFD (French Development Agency, Comorian Health Sector } \\
\text { Support Project, PASCO) }\end{array}$ & \\
\hline Global Fund & 752179105 \\
\hline UNAIDS & 12110000 \\
\hline GAVI & 14176864 \\
\hline JICA & 112339605 \\
\hline $\begin{array}{l}\text { COI-AIRIS (Indian Ocean Commission - Support for the Regional } \\
\text { STI/AIDS Prevention Initiative) }\end{array}$ & 54841807 \\
\hline Damien Foundation & 59532000 \\
\hline AFD+ SC-CF (Secours Catholique Caritas France+Caritas Comores & 226377287 \\
\hline Qatar Charity & 32765600 \\
\hline IsDB ( TA project) & 283485545 \\
\hline Red Crescent, Qatar & 9671550 \\
\hline Sub-total & 4373192528 \\
\hline Total & $\mathbf{5 2 2 6 9 9 2 5 2 8}$ \\
\hline
\end{tabular}




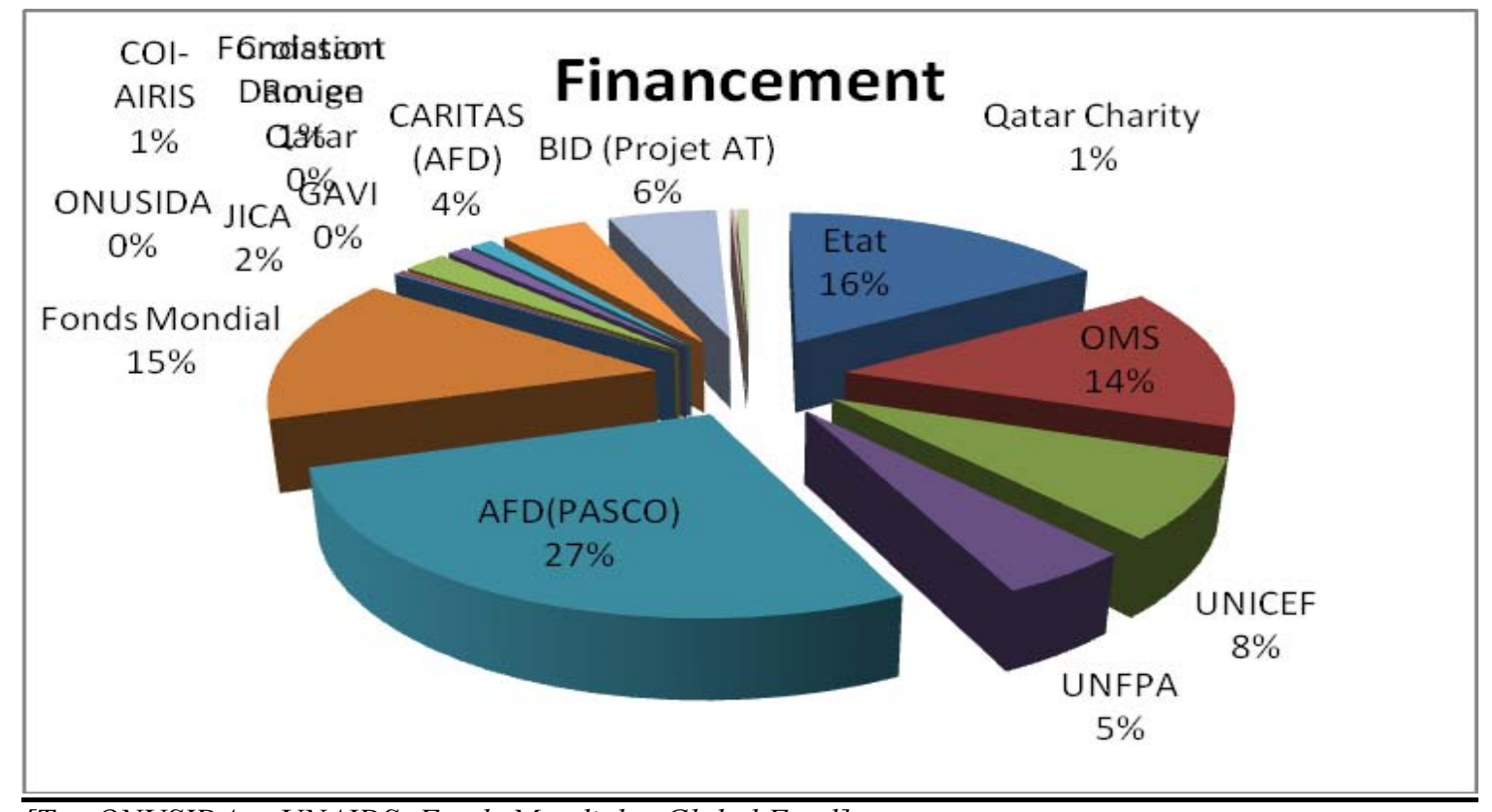

[Tr.: ONUSIDA = UNAIDS: Fonds Mondial = Global Fund]

\section{Outlook and recommendations}

The principal recommendations are:

$\checkmark$ Increase the health sector's share of government budget financing to 15 percent so as to meet the Abuja goal, pursuant to WHO recommendations

$\checkmark$ Prepare and implement a strategy for mobilizing resources to develop the health sector

$\checkmark$ Ensure that data are available, distributed, disseminated and used

$\checkmark$ Endow health facilities with qualified human resources at every level, in accordance with established regulations

$\checkmark$ Prepare the 2012-2016 National Strategic Plan to Combat Malaria

$\checkmark$ Strengthen epidemiological surveillance and the mapping of active or potentially epidemic foci in the areas at the pre-elimination of malaria phase.

$\checkmark$ Carry out the Campaign to Expedite Reduction of Maternal Mortality in Comoros (CARMMA)

$\checkmark$ Improve performance in hospitals, the pharmaceutical system and laboratories 
$\checkmark$ Expand health infrastructure coverage to reach 80 percent compliance with standards

$\checkmark$ Increase and maintain immunization coverage to 90 percent for all antigens and in all districts

$\checkmark$ Develop an Integrated Strategic Health-related Communications Plan

$\checkmark$ Ensure that all STI patients receive proper treatment.

\section{Core strategy 5: Promote education and vocational training with a view to developing human capital}

The education sector in Comoros helps produce an educated, socially responsible, population capable of making the most of economic opportunities. With that in mind, the programs and projects implemented aim to:

$\checkmark$ Develop education, technical education, and vocational training in line with the job market

$\checkmark$ Improve both access to and the quality of basic (pre-school and elementary) and secondary education

$\checkmark$ Develop competent human resources and the sector-wide approach (Swap) in education

$\checkmark$ Promote literacy campaigns and sports and cultural activities.

Implementation of programs and projects in this sector has focused on:

$\checkmark$ Preparation and validation of the 2011 Education Sector Performance Indicators

$\checkmark$ Preparation and validation of the 2011 Annual Work Plan of the Ministry of Education

$\checkmark$ Preparation of the Government Report on the National Education System

$\checkmark$ Copying, distribution and dissemination of the 2010-2015 Education and Training Master Plan

$\checkmark$ Organization of the Seventh National Conference on Education 


\begin{tabular}{|c|c|c|c|}
\hline Priority indicators & $\begin{array}{l}\text { Benchmark, } \\
2010\end{array}$ & $\begin{array}{l}\text { Target, } \\
2011\end{array}$ & $\begin{array}{l}\text { Achieved in } \\
2011\end{array}$ \\
\hline $\begin{array}{l}\text { Percentage of secondary school } \\
\text { pupils enrolled in technical } \\
\text { education and vocational training } \\
\text { schools }\end{array}$ & $3 \%$ & $15 \%$ & $8 \%$ \\
\hline $\begin{array}{l}\text { Percentage of pupils that have } \\
\text { passed the baccalaureate exam who } \\
\text { are admitted to the first year of the } \\
\text { University of Comoros (UDC) }\end{array}$ & $50 \%$ & $77 \%$ & $60 \%$ \\
\hline Pre-school enrolment ratio & $5.1 \%$ & $45 \%$ & $16 \%$ \\
\hline Gross enrolment ratio & $95 \%$ (primary) & $100 \%$ & $\begin{array}{l}104.3 \% \\
\text { (primary) } \\
43.06 \% \\
\text { (secondary) }\end{array}$ \\
\hline Net school enrolment ratio & $\begin{array}{l}77.1 \% \\
\text { (primary) }\end{array}$ & & $\begin{array}{l}79.4 \% \text { (primary) } \\
16.37 \% \\
\text { (secondary) }\end{array}$ \\
\hline Net admission ratio & $\begin{array}{l}34.6 \% \\
\text { (primary) }\end{array}$ & & $60 \%$ (primary) \\
\hline Primary school completion ratio & $57 \%$ & & $62 \%$ \\
\hline $\begin{array}{l}\text { Gap between Net Enrolment Ratios } \\
\text { for girls and boys }\end{array}$ & $4 \%$ & $2 \%$ & $4.77 \%$ \\
\hline $\begin{array}{l}\text { Percentage of Education Boards that } \\
\text { prepared and implemented annual } \\
\text { action plans }\end{array}$ & $10 \%$ & $30 \%$ & $100 \%$ \\
\hline $\begin{array}{l}\text { Literacy rate among the population } \\
\text { aged } 15+\end{array}$ & $60 \%$ & $69 \%$ & $56.5 \%$ \\
\hline
\end{tabular}

Source: Education sector performance indicators 2010/2011 and RESEN 2011

The above Table shows that the technical and vocational education enrolment rate increased by five percentage points, from 3 percent in 2010 to 8 percent in 2011, thanks to the growth in the number of technical education and vocational training establishments, but remains well below the 15 percent target set for 2011 .

Regarding admission to the University of Comoros, there was a significant hike in the admission rate for baccalaureate holders to the first year of the UDC (from 50 percent in 2010 to 60 percent in 2011), thanks to the marked increase in those who passed the baccalaureate exam (33 percent) in 2010. Despite the higher rate of admissions, the country's still very fledgling university was not able to achieve the 2011 target of 77 percent due to its insufficient absorption capacity, which meant that large numbers of those passing the baccalaureate exam immigrated to foreign universities.

The pre-school enrolment rate in 2011 was 16 percent, a significant increase of 10.9 percentage points in just one year (2010: 5.1 percent). Despite that promising trend, the country did not meet the established target of 35 percent. The shortfall was due, among other factors, to lack of funding and the dilapidated state, as well as shortage, of 
classrooms in the $E C R$. However, major efforts to improve this indicator have been noted thanks to the multifaceted support of the Technical and Financial Partners (TFP) active in this sector, with respect to the formulation of early childhood education policy, the rehabilitation of pre-school classrooms, and the provision of pedagogical and didactic materials and of training for supervisors and teachers in teaching methods and the use of schoolbooks and teachers' guidelines for early childhood education.

As regards completion of primary school, Comoros increased the ratio by five percentage points in 2001 to 62 percent from 57 percent in 2010. As a result, the percentage of children not completing primary school in 2011 was 38 , that is to say approximately 28,000 children aged 6 to 11 .

As for admission, the net ratio of admission to primary school almost doubted between 2010 to 2011 (from 34.6 percent to 60 percent), a remarkable improvement of 25.4 percentage points, thanks especially to improved access to basic education. In addition, the Table above illustrates the marked increase in the gap between gross and net school enrolment rates from 2010 to 2011 in the two primary and secondary school cycles. Indeed, the gap between these two indicators was 17.9 percent in 2010 (Gross enrolment rate 95 percent, net 77.1 percent) and 24.9 percent in 2011, a worrying increase of 7 percent points during this period. For that reason, a considerable effort has been made to enhance supervision, to provide initial and continuous training for teachers and supervisors in primary and secondary schools, and to build, rehabilitate and equip classrooms in both cycles in order to achieve the ultimate goal of narrowing that gap, which will make it possible to improve access to and the quality of education for all in keeping with the country's international commitments.

The gap between the NER for girls and that for boys in primary school unfortunately increased in 2011 by 0.7 percent (to 4.7 percent, from 4 percent in 2010), even as the efforts of the MEN, supported by the TFPs, to promote the enrollment of girls produced encourage results in terms of the percentage of girls enrolled. Indeed, the NER for girls increased from 70.9 percent to 77.0 percent in primary school, from 18.6 percent to 22.3 percent in the first cycle of secondary school, and from 10.7 to 11.17 percent in the second cycle of secondary school between 2007 and 2011.

The boy/girl ratio indicator pointed to encouraging developments in all cycles of the educational system, rising from 0.80 to 0.90 at the primary school level, from 0.81 to 0.98 in the first cycle of secondary school, from 0.88 to 1.01 in the second cycle of secondary school and from 0.68 to 0.81 in higher education between 2008 and 2011. In higher education, girl/boy parity has been trending in favor of girls for these past four years, even though boys are still a majority ( $(40,60$ percent, 41.26 percent, 41.97 percent and 44.76 percent for girls; versus 59.40 percent, 58.74 percent, 58.03 percent and 55. 24 percent for boys in 2008 to 2011).

As for the number of Education Boards that drew up and implemented Annual Action Plans, it was ascertained that all the MEN institutions did so. That positive achievement owes much to the determination of His Excellency, Dr. IKILILOU DHOININE to introduce results-based management in public administration.

Regarding management of the educational system, all its directorates and departments are manned by qualified and competent staff; however, they do require need ongoing training, refresher courses, and more appropriate and productive redeployment. 
With respect to literacy campaigns, estimates culled from the department in charge point to a 3.5 decline in the literacy rate in 2011 from a peak of 60 percent attained in 2010 .

This disappointing development is mainly due to a lack of sensitization of the population to the importance of literacy, lack of training for those most in need of it, lack of funding, the dearth of I.T. equipment and furniture, a shortage of qualified and competent personnel in the Directorate, and, finally, to a lack of political will when it comes to literacy campaigns. With a view to remedying these constraints, major steps are now being taken to boost the Directorate's capacity, conduct awareness campaigns with local communities and NGOs, and involve the competent authorities in promoting and developing literacy tuition nationwide.

Further, noteworthy efforts have been made in the area of sports and cultural activities, including the rehabilitation of the Ivembéni stadium and the Vassy platform in Anjouan, the construction of a (1) Reading Room and Educational Center for Young People in Moya, mthe construction of a (1) Media Center in Chouani by the Fund for Social Development, FSD (French embassy) and support for the establishment of four (4) Centers for Reading and Cultural Activities (CLAC) by the International Organisation of La Francophonie (OIF).

As regards budget allocations, the Government of the Union of Comoros allocated KMF 1222809191 to the sector in 2011, including KMF 846056311 for transfer expenses, KMF 4116475 in outlays on goods and services and KMF 120636405 in investment expenditures.

Public expenditure on education amounted to 4.9 percent of GDP in 2011. That is higher than the regional average and suggests that the system is not under-financed. However, most of the expenditure is on wages, leaving little room for maneuver with regard to nonwage operating expenses, which are, however, vital to ensure quality of the services provided.

\section{Financing}

\begin{tabular}{|l|l} 
Programs and projects & Cost in 2011 (KMF)
\end{tabular}

Priority Program 1 : Develop education, technical education and vocational training in line with the job market

\begin{tabular}{|l|l|}
\hline JAPAN & 383232084 \\
\hline $\begin{array}{l}\text { STEP (Support Technology for Educators and } \\
\text { Parents)/ATEC }\end{array}$ & 63546917 \\
\hline ILO & 300000000 \\
\hline UNESCO & 112000000 \\
\hline $\begin{array}{l}\text { Foumbouni Community } \\
\text { France }\end{array}$ & 40000000 \\
\hline $\begin{array}{l}\text { Priority Program 2 Improve both access to and the quality of basic (pre-school and } \\
\text { elementary) and secondary education }\end{array}$ & 39399161 \\
\hline $\begin{array}{l}\text { UNICEF } \\
\text { APLACO (Support for Development Planning and }\end{array}$ & 16002000 \\
\hline COMITE ARABE (Qatar Charity) & 105000000 \\
\hline JAPAN & 100580052 \\
\hline
\end{tabular}




\begin{tabular}{|l|l|}
\hline UNITED STATES OF AMERICA & 80000000 \\
\hline STEP/ATEC & 12000000 \\
\hline $\begin{array}{l}\text { Priority Program 3 : Develop competent human resources and the sector-wide approach } \\
\text { (Swap) in education }\end{array}$ \\
\hline APLACO & 5446500 \\
\hline UNESCO & 94500000 \\
\hline France & 98400000 \\
\hline Priority Program 4: Promote literacy campaigns and sports and cultural activities \\
\hline OIF (International Organisation of La Francophonie) & 82000000 \\
\hline UNESCO & 3500000 \\
\hline FRANCE & 85441485 \\
\hline TOTAL & $\mathbf{2 0 7 3 3 9 3 ~ 3 0 0}$ \\
\hline
\end{tabular}

\section{Distribution of sources of finance}

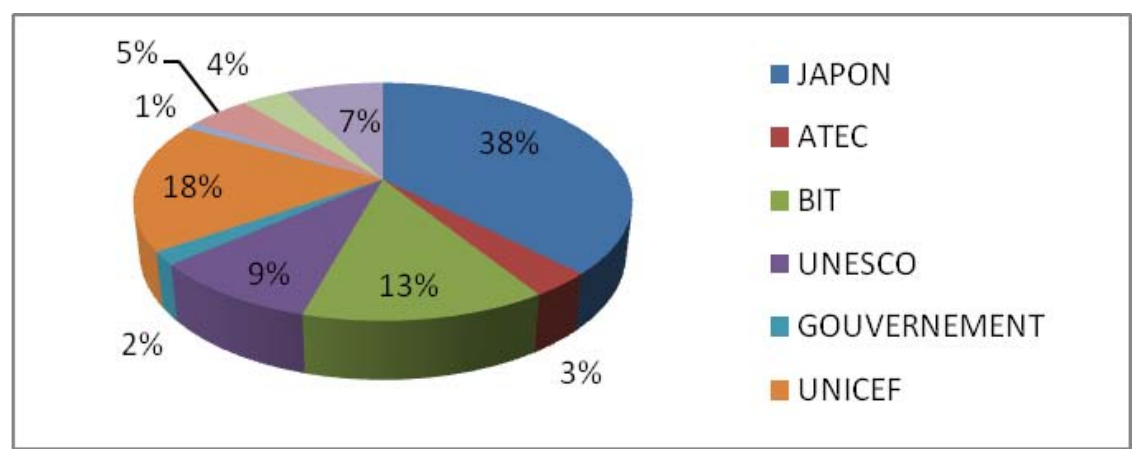

STEP/ATEC, ILO, UNESCO, GOVERNMENT, UNICEF]

[Key: JAPAN,

\section{Box: Analysis of HIPC indicators/Education}

The Heavily Indebted Poor Countries Initiative (HIPC) completion point triggers are an International Monetary Fund initiative designed to help developing countries cope with the problems that hamper their social and economic development, especially their accumulated external debt, subject to a certain number of conditions. Thus, the United Nations has defined several economic and social indicators that countries wishing to benefit from these advantages have of necessity to meet within an established time frame. In light of the above Table, achievement of those indicators in the Union of Comoros by end-2012 (the deadline established for Comoros) appears feasible if the country, in collaboration with its TFPs, redoubles its efforts in particular with respect to the construction of latrines and the distribution of books. With respect to these indicators, the country has built 86 of the 100 latrines requested (an achievement ratio of 86 percent) and distributed 38,900 books (an achievement ratio of 13 percent).

With respect to school kits, the country has already exceeded the quota of 25,000 school kits by distributing more than 66,100 sets of school supplies to the nation's schools (an achievement rate of more than 260 percent). As for school infrastructure, Comoros has built/rehabilitated and equipped 303 primary school classrooms, an achievement rate of more than 144 percent, between 2010 and 2011, exceeding the target of 210 classrooms. The Union of Comoros owes much of this achievement to the support of its TFPs in the 
sector, especially UNICEF, the Community Development Support Fund (FADC), the Technical Assistance to the Education Sector Support Programme in the Comores (PASEC), Qatar Charity, and others.

Overall, these factors enable us to state the Union of Comoros is well on the way to meeting, by end-2012, the HIPC indicator targets for the educational sector, assuming it is able to maintain current efforts and commitments.

\section{Outlook and recommendations}

The outlooks and recommendations are:

Mobilize the financial resources needed for the sector

$\checkmark$ Strengthen the capacities of both the institutions and personnel in the educational system

$\checkmark$ Improve access to and the quality of education at every level

$\checkmark$ Establish and embark on initiatives to remedy the disastrously low level of literacy and to develop cultural activities and sports in the Union of Comoros.

\section{Core strategy 6: Promote environmental sustainability and civil security}

Several programs and projects are under way in Comoros to protect the environment and safeguard its regeneration, conservation, and rational and sustainable exploitation aimed at ensuring the well-being of this and future generations. Those programs and projects specifically seek to:

$\checkmark \quad$ Conserver biodiversity and share the benefits from it equitably

$\checkmark \quad$ Preserve and promote agricultural biodiversity

$\checkmark \quad$ Adapt to climate change

- Develop environmental management and multi-sector coordination capabilities

Put in place mechanisms to prevent and manage risks relating to natural and climatic disasters.

In 2011, the implementation of programs and projects focused on: 
Participation of Comoros in the world Climate Change Conference in Durban

The Itsandra Manifest on partnership for green development in the Union of Comoros

The signing of the agreement between the Government and the UNDP on implementation of the ACCE project

Establishment of the Civil Security Department (Direction Générale de la Sécurité Civile)

Drafting of cyclone and tsunami plans

The national reforestation campaign

The extensive study on vulnerability to the principal climatic hazards

The study on vulnerability to climate change (Aclimate-COI project)

The joint communiqué between the United Nations and the Government of the Union of Comoros on the need to expedite implementation of programs concerning water, energy, agriculture and protected areas.

Analysis of priority indicators

\begin{tabular}{|l|l|l|}
\hline Performance indicators & Target & \multicolumn{1}{|c|}{$\begin{array}{c}\text { Achieved in } \\
2011\end{array}$} \\
\hline Number of zoning plans for selected sites & 2 & 3 \\
\hline Number of co-management agreements & 2 & 36 \\
\hline Number of flora and fauna inventories carried out & 2 & 5 \\
\hline $\begin{array}{l}\text { Number of people who received training in } \\
\text { developing and strengthening their capacity to } \\
\text { manage profitable activities }\end{array}$ & 100 \\
\hline Area reforested & 500 hectares & 572 hectares \\
\hline Area of land devoted to agricultural biodiversity & $30 \%$ & $20 \%$ \\
\hline Number of emergency relief plans drawn up & 2 & 2 \\
\hline $\begin{array}{l}\text { Population and institution familiar with precautions } \\
\text { to be taken for disaster response }\end{array}$ & $50 \%$ & $30 \%$ \\
\hline $\begin{array}{l}\text { Vulnerability maps drawn up } \\
\text { Number of adaptation measures implemented }\end{array}$ & 2 & 3 \\
\hline $\begin{array}{l}\text { Number of programs/projects financed to } \\
\text { strengthen Integrated Management of Coastal }\end{array}$ & $\mathbf{3}$ & $\mathbf{1 2}$ \\
\hline
\end{tabular}


Source: Department of the Environment

\section{- Number of zoning plans in selected sites}

The three zoning plans drawn up in 2011 made it possible to establish the boundaries of the priority sites for the conservation of biodiversity, namely the Karthala forest (Ngazidja), the Mont Ntringui forest (Anjouan and the wet Mohéli forest (Mlédjélé Mohéli).

The demarcation and zoning were preceded by phytoecological studies of the three sites and negotiation of natural resource (fauna, flora, water) co-management agreements, with a view to establishing regulations at the local level. Thirty-six (36) riverside communities inhabit the three sites chosen.

\section{- Number of fauna and flora inventories carried out}

The carrying out of five fauna and flora inventories in the priority biodiversity conservation areas exceeds the targets set for 2011. The inventories were conducted with support form the community-based organizations (OCB) and the Community Commitment to Sustainable Development (ECDD) projects and the National Forest Inventory office (IFN).

\section{- Number of people trained}

In 2011, 1,531 people were trained in a number of fields with a view to building and strengthening their ability to manage income generating activities (AGR) in connection with the goals of preserving and making sustainable use of natural resources.

\section{- Number of farmers who adopted productivity-enhancing methods and} systems

In 2011, 965 people received training in the adoption of methods and systems for increasing productivity in traditional agro-forestry and in integrated pest management techniques and organic farming. These methods are germane to biodiversity conservation efforts.

\section{- Area devoted to agro-biodiversity}

In 2011, it was discovered that 20 percent of the national territory is suited for agrobiodiversity. The annual target could not be met for lack of funding.

\section{- Reforested areas}

In 2011 , only 22 percent of degraded soils were restored and 572 hectares were reforested. Those reforestation efforts were undertaken with the support, in particular, of the Global Environment Facility's Small Grants Program (SGP), the aforementioned OCB, the National Program for Sustainable Human Development (PNDHD), the ECDD, and Sustainable Land Management (GDT). These activities were conducted as part of the national reforestation campaign, which began in 2010 under the motto "a tree for every Comorian" (un comorien, un arbre). Thus, more than 300,000 trees were planted in 2011. Rehabilitation of forest areas will continue in 2012. 
- Disaster relief planning

In 2011, the Civil Security Department was strengthened nationally and on the islands with respect to the coordination, organization and preparation of emergency relief. The support led to the preparation of Specialized Relief Plans (PSS) in the event of cyclones and tsunamis, as well as to updating of the national contingency plan.

- Population and institutions familiar with the precautions to be taken to respond to a disaster

The share of institutions familiar with actions needed to respond to a disaster is thought to be 30 percent. That is as a result of huge awareness campaigns directed at elected officials, préfets, mayors, and primary school teachers. Further major effort is needed to sensitize communities living in priority geographical areas.

\section{- Mapping of vulnerability}

A vulnerability study of the main climatic and natural hazards led, with support from the Acclimate project, to the drawing up of three vulnerability-to-risk maps (volcanoes, floods, and landslides).

\section{- Number of steps taken for adaptation to climate change}

The Small Grants Program enabled the Government to exceed the annual target for this indicator. Indeed, it financed 12 studies and/or projects involving adaptation to climate change measures. The actions will affect the following sectors: sustainable agriculture, commercial fishing, the development of rural ecotourism, agroforestry, and clean forms of energy.

- Number of programs/projects financed to strengthen integrated management of coastal areas

The annual target for this indicator could not be reached for lack of funding. Only two microprojects were implemented, with funding from the SGP, to shore up coastal areas in 2011 in Moindzazaboini and Ndroudé.

\section{- Number of nurseries and cuttings banks}

In 2011, the Department of the Environment registered the establishment of 20 nurseries and 3 cuttings banks nationwide. This achievement, which exceeds the annual target, was thanks to the involvement of the PNDHD and SGP programs in the implementation of plant production capacity building policies in the three protected area zones.

\section{Financing}

\begin{tabular}{|l|l|l|}
\hline Donors and creditors & Contributions to: & $\begin{array}{l}\text { Amount (in millions of } \\
\text { KMF) }\end{array}$ \\
\hline UNDP & Forestry inventory & 84.773 \\
\hline FAO & IGA/Biodiversity & 21.06 \\
\hline $\begin{array}{l}\text { POWPA (Program of } \\
\text { Work on Protected Areas) }\end{array}$ & Biodiversity & 0.63 \\
\hline Comorian Government & $\begin{array}{l}\text { Technical and material } \\
\text { support }\end{array}$ & 96.33 \\
\hline GEF/SGP & Adaptation to climate & 137.200 \\
\hline
\end{tabular}




\begin{tabular}{|l|l|l|}
\hline & change & \\
\hline UNEP & Biodiversity & 70 \\
\hline $\begin{array}{l}\text { BCPR (Bureau for Crisis } \\
\text { Prevention and Recovery) }\end{array}$ & Soil restoration & 37.05 \\
\hline GEF/UNDP & Biodiversity & 132 \\
\hline Total & & $\mathbf{5 7 8 . 4 4 3}$ \\
\hline
\end{tabular}

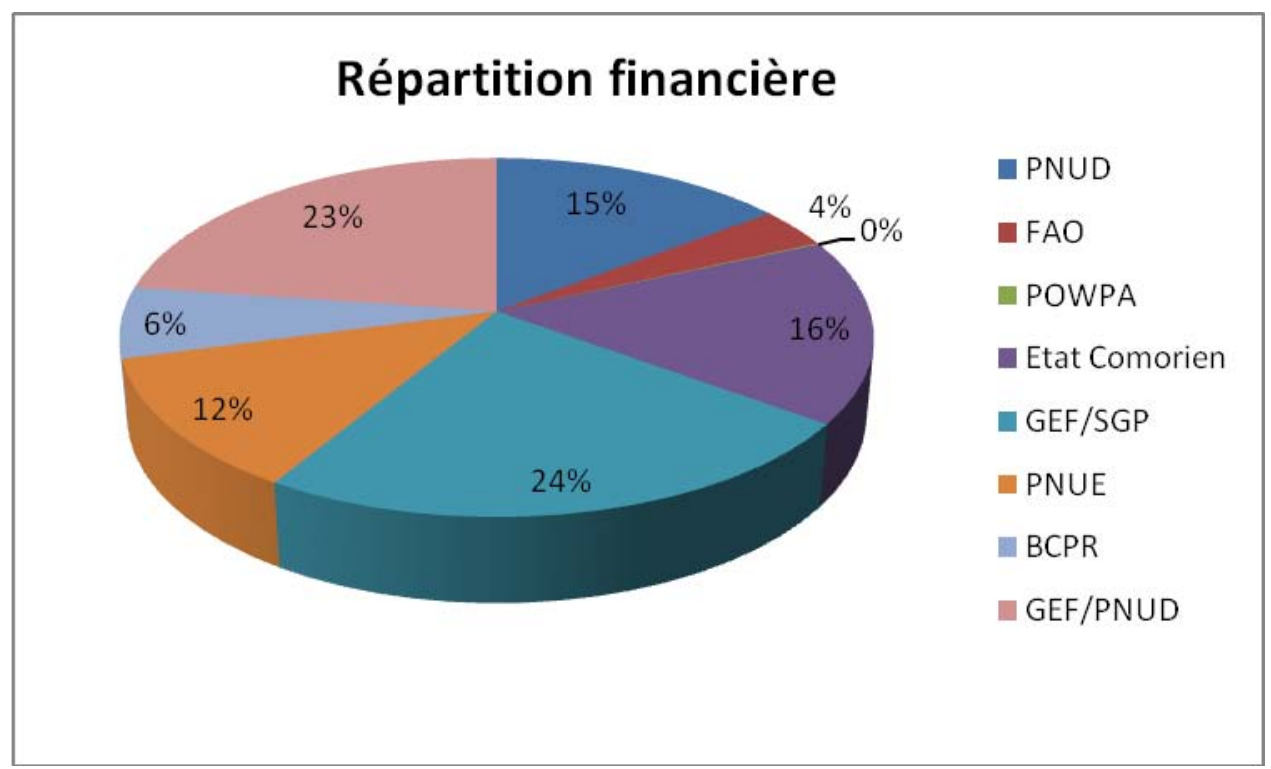

[Key: see above. Distribution of funding]

\section{Outlook and recommendations}

As regards recommendations, an effort should be made to:

Increase the number of protected areas

Provide small farmers with the wherewithal for sound management of natural resources

Introduce measures tailored to the living conditions of the most vulnerable

Restore soil fertility which is vital for the production system

Develop income generating activities (IGA) (such as beekeeping, ecotourism) in zones where protected areas are established

Guarantee land tenure security for the lowest-income farmers

Ensure sound distribution of the resources mobilized 
Strengthen stakeholders' institutional and individual capacities

Develop policies and bodies that will guarantee land tenure security for the most vulnerable farmers

Strengthen environmental management and multi-sector coordination capabilities

Enhnace integrated management of coastal areas

Facilitate access to information and communication technologies

Mobilization of resources

\begin{tabular}{|l|l|l|l|}
\hline Sector & $\begin{array}{l}\text { Programmed } \\
\text { Resources } \\
\text { (in millions of KMF) }\end{array}$ & $\begin{array}{l}\text { Resources Mobilized } \\
\text { (in millions of KMF) }\end{array}$ & Percentage \\
\hline Public finance & 14690 & 262.2 & $1.78 \%$ \\
\hline Commerce & 518 & 119.25 & $23.02 \%$ \\
\hline Energy & 14184 & 2970 & $20 \%$ \\
\hline Infrastructure & 12,225 & 5581 & $45 \%$ \\
\hline Water, sanitation & 8127 & 1592.5 & $20 \%$ \\
\hline Private sector & 863 & 181.1 & $21 \%$ \\
\hline Agriculture & 4295 & 605 & $14.09 \%$ \\
\hline Livestock & 3478 & 202.09 & $5.81 \%$ \\
\hline Fishing & 2137 & 1197 & $56.02 \%$ \\
\hline Tourism & 1415 & 444.75 & $31.43 \%$ \\
\hline Governance & 4676 & 5300 & $113 \%$ \\
\hline Education & 6083 & 2073 & $34 \%$ \\
\hline Health & 14075 & 5226 & $38.5 \%$ \\
\hline Environment & 6181 & 534 & $8.6 \%$ \\
\hline Total & $\mathbf{9 2 9 7 7}$ & $\mathbf{3 1 . 5 7 7 . 8 9}$ & $\mathbf{4 0 \%}$ \\
\hline & & &
\end{tabular}

The resources put to work amount to 40 percent of programmed financial resources. The water, sanitation and governance sectors received more than the amounts programmed. However, as regards resource mobilization, much more needs to be done for the social sectors. The same is true of the private sector, which serves as the engine of economic growth 


\section{ANALYSIS OF IMPLEMENTATION AND MONITORING AND EVALUATION}

\section{The institutional framework for monitoring the PRGS}

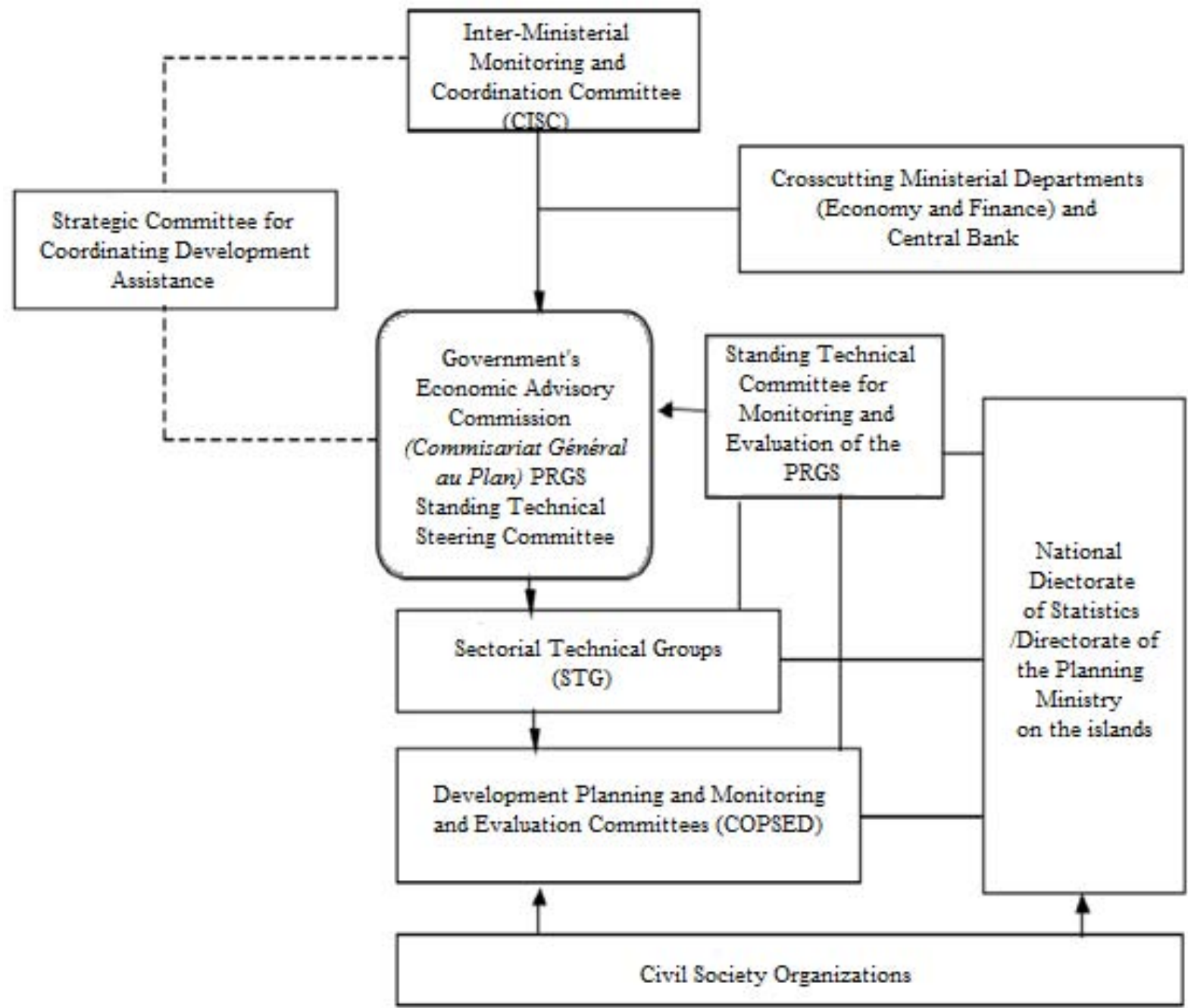


The institutional framework for implementation and monitoring and evaluation of the strategy was established by Decree $\mathrm{N}^{\circ} 10-108 / \mathrm{PR}$ of August 31, 2010. It covers the line ministries, the regional administrations, the technical and financial partners, civil society and the private sector. It breaks down into seven (7) bodies:

The Inter-Ministerial Monitoring and Coordination Committee (CISC) This body is chaired by the Secretary General of the Government and comprises all the members of the Council of Ministers. Its mandate is to take political decisions and engage in dialogue with the partners in development. In that capacity, it coordinates occasional meetings to keep abreast of progress made with implementing programs and projects under the PRGS. In 2011, the CISC met on Wednesday, March 16 to assess progress made in 2010 with respect to implementation of the strategy.

\section{The Strategic Committee for Coordinating Development Assistance (CSCAD)} The Strategic Committee for Coordinating Development Aid is chaired by the Head of State. It comprises the members of a Special Council of Ministers and technical and financial partners (TFP). The Government's Economic Advisory Commission (Commisariat Général au Plan) acts as its secretariat. This Committee is responsible for providing properly coordinated effective development assistance in Comoros. As a highlevel body for dialogue, it held a meeting in the Itsandra Hotel on October 17, 2011 to discuss and review implementation of the PRGS in 2010. Through the Commission, the Government took good note of the comments made at the meeting and the methodological note on the 2011 review process incorporated them.

\section{The Technical Steering Committee (CTP)}

The CTP is the body responsible for supervising, coordinating, and steering the implementation, as well as the monitoring and evaluation, of the PRGS. In fact, it lies at the heart of the implementation and monitoring and evaluation mechanism. It is supported by the PRGS's Permanent Technical Secretariat for M \& E, which acts as its right arm and secretariat. It ensures that the M\&E mechanism functions properly and abides by its monitoring and reporting schedules. It is composed of the Secretaries General of the ministries; representatives of the technical and financial partners, the private sector and civil society; and the Planning Directors of the islands. The PRGS Steering Committee is chaired by the Head of the Government's Economic Advisory Committee (Commissaire général au Plan). In 2011, the Steering Committee met several times to steer the end of the 2010 and the end of the 2011 strategy implementation review process.

\section{Standing Technical Secretariat (STP)}

The STP works closely with the Sectoral Technical Groups (GTS), which are responsible for planning, implementing and managing programs and projects, monitoring their execution, and collecting sector data. It plays a key role in the entire institutional framework and looks at PRGS implementation on a daily basis. It is responsible for preparing the annual strategy implementation report and, in that capacity, works with the GTS and in close coordination with the Development Planning and Monitoring and Evaluation Committees.

The National Department of Statistics (DNS)/ Decentralized organs of the Ministry of Planning in the three (3) islands

The DNS is the body officially in charge of gathering and analyzing statistical data. Within the PRGS monitoring and evaluation mechanism, the Statistics Department 
coordinates the data collection mechanism, in close collaboration with the decentralized organs of the Ministry of Planning on the islands, by implementing the National Statistics Development Strategy (SNDS). In that capacity, it is responsible for conducting and supervising data collection operations nationwide; for producing various reports on the social and economic development of the country and household living conditions; and for helping to produce progress and performance reports in coordination with the bodies involved in implementation and monitoring and evaluation of the PRGS.

The Comprehensive Household Survey (EIM) of 2004 and the Multiple Indicators Cluster Survey (MICS) of 2005 are the most recent major surveys conducted in the country. With the support of its partners, the Government has been working since preparation of the final version of the PRGS on building a statistical service endowed with sufficient human, material and financial resources to make an effective contribution to the formulation, monitoring and evaluation of economic and social development policies, programs and projects, especially the PRGS and the Millennium Development Goals (MDGs). To that end, a Demographic and Health Survey along with a multiple indicator cluster survey were launched in 2011. The idea of these surveys is to discover levels and trends in fertility and in infant and child mortality and the factors that shape them; to determine knowledge and use of contraception methods by women and men and to elicit information on the ideal number of children and on attitudes in men and women of child-bearing age toward family planning; to gather detailed data on mother and child health; to collect detailed data on the sexuality of young people and on women's and men's opinion regarding AIDS and sexually transmitted infections (STI); and to estimate the scope of gender-related violence and trauma. The findings of this survey are due to become available in 2013.

In 2011, the Government raised two hundred and thirty-five million Comorian francs with the African Development Bank to carry out phases one and two of the 1,2,3 survey. The operation began with the signing of the survey memorandum in 2011 and will end in May 2013.

\section{The Sectorial Technical Groups (GTS)}

There are nine GTS. The sectors that have them are: (1) public finance; (2) infrastructure; (3) energy, water and sanitation; (4) the private sector; (5) agriculture, fisheries, and livestock; (6) governance; (7) health; (8) education; and (9) the environment. The GTS produce important information for monitoring and evaluating the PRGS. In particular, they help monitor execution of priority programs by making information available regarding progress made with programs and projects. In that sense, preparation of the Annual Work Plan (AWP) provides an operational basis for implementing and monitoring execution of the PRGS's priority programs. This technical mechanism enables ministries to analyze, on an annual basis, the extent to which their program outcomes are achieved and to relate them to the resources allocated to them. As with the 2010 strategy implementation review, the 2011 review also involved each GTS producing and validating a progress report. The meetings to validate the nine reports ran from June 22 to June 17, 2012. The consolidation of these different reports serves as a 2011 monitoring report on PRGS implementation.

The GTS are chaired by the Secretaries General of the Ministries and composed of technical staff from the ministries, the TFPs, civil society and the private sector.

Development Planning and Monitoring and Evaluation Committees (COPSED) on the three (3) islands. 
These committees produce vital information for monitoring and evaluating the PRGS on the islands. They work closely with the GTS to plan, implement, monitor and evaluate development programs and projects. The COPSED have direct ties with the beneficiaries and are therefore at the forefront of the $\mathrm{M} \& \mathrm{E}$ mechanism. Thus, the gathering of data on program and project implementation began with preparation of the 2011 report at the regional administrations level. Meetings to validate the data were held on May 31, 2012 in Fomboni for the Mohéli COPSED; on June 1, 2012 in Mutsamudu for the Anjouan COPSED; and on June 2 in Moroni for the Grand Comore COPSED. The GTS relied extensively on these data for drawing up their reports.

\section{PRGS implementation and monitoring instrument}

The PRGS is implemented through Annual Work Plans, which constitute the operational link between the PRGS and its priority action plan. Thus, after taking office in May 2011, the Government of His Excellency Dr. IKILILOU DHOININE sent his Ministers appointment letters instructing them to achieve certain results over time. The interpretation of those engagement letters relied essentially on the PRGS action plan and let to Annual Work Plans (AWPs) being drawn up for all ministerial departments. Monitoring and evaluation of these AWPs is conducted every six months, with the Head of State chairing the process. The conclusions of those evaluations have been built into this report. The 2012 evaluations will begin by monitoring program and project implementation by the island administrations in accordance with the central authorities' instructions. It is worth pointing out that in 2011 the Union of Comoros proceeded to establish priorities within its 2010-2014 plan of action because the 2010 review stressed in its conclusions that it was ambitious and required financial and human resources that were not available for that period.

\section{Resource mobilization instrument}

The principal instruments for raising funds are:

\section{The Doha Conference on Development and Investment in Comoros}

A meeting to follow up on the Doha Conference on Development and Investment in Comoros was held in Moroni on February 23 and 24, 2011. The purpose of the meeting was to expedite mobilization of the resources promised at the Conference. The Arab partners present at the meeting ratified the promises made in Doha and several recommendations were made:

1) The Comorian authorities need to ask Qatar and the Islamic Development Bank, at the highest level, to use their good offices to persuade the partners to be more diligent.

2) The Comorian authorities must also take suitable measures to foster a favorable environment for mobilizing and absorbing official development assistance by improving overall governance in the country and implementing key sector policy reforms. 
3) The authorities must also establish a national committee to clarify the responsibilities of the various committees and speak with one voice.

- The Aid for Trade program with its principal instrument : the Enhanced Integrated Framework

The Union of Comoros acceded in 2010 to Category 1 of the Special Allocation Fund of the Enhanced Integrated Framework. Since 2011, the country has been implementing a three-year Category 1 project with a budget of US $\$ 1.3$ million. Comoros has also received agreement in principle on its eligibility for Category 2 resources if it formulates two US\$3 million projects.

Satisfactory implementation of the Enhanced Integrated Framework project paved the way for the Round Table to mobilize additional Aid for Trade resources, scheduled for September 2012 in Geneva. A medium-term plan derived from the 2010 resource mobilization strategy listed requirements totaling US\$20 million to finance the other priority actions in the Diagnostic Trade and Integration Study (DTIS) Action Matrix.

\section{- Program supported by the IMF's Extended Credit Facility}

This instrument handled by the IMF is a program that aims to lower or cancel accumulated debt. In a difficult environment, Comoros has passed the decision point and is well on the way to achieving the HIPC completion point. This multilateral instrument offers excellent opportunities for development financing by cancelling the stock of debt, as under the terms of the program the resources for repaying the outstanding debt can be devoted to priority development programs. Moreover, as completion point also represents the culmination of major structural reforms and an indication that financial governance is improving, the success of the IMF program sends a strong signal to the donor community to make further commitments to the country, by contributing the additional resources needed to finance the country's social and economic development within the framework of a pro-poor growth strategy.

\section{Implementation of the Paris Declaration}

The Union of Comoros draws heavily on Official Development Assistance (ODA). ODA finances the bulk of its investments due to the structural weakness of domestic resources. After having formally subscribed to the Paris Declaration in 2008, Comoros set about implementing it. Thus, an Assistance Coordination Mechanism was adopted, which includes inclusive institutional arrangements, already in place, and an assistance information management platform, which is currently being constructed.

In 2011, Comoros participated for the first time in surveys following up on the Principles for Good International Engagement in Fragile States and on implementation of the principles upheld in the Paris Declaration on Aid Effectiveness. The country's participation in these surveys is consistent with the Government's commitment to significantly improve the effectiveness of Official Development Assistance and make it a truly supportive tool in the country's efforts to expedite economic growth and reduce poverty.

Lessons learned and priority actions to be pursued in follow-up to the Paris Declaration include: 
- Proceeding, in connection with the PRGS mid-term review, to conduct a broader and more in-depth analysis of the causes of fragility, and including priority actions in the next plan of action

- Strengthening the national planning and programming system

- Resident donors and creditors should undertake joint analyses with nonresident donors and creditors and establish consensus building systems with them

- The Government and the donors and creditors need to re-examine the relevance of the indicators chosen for monitoring the PRGS during the mid-term review

- Establishing mutual responsibility mechanisms.

It is important to point out that the conclusions of these surveys reflect the findings of the dialogue among 62 stakeholders, representing all national and international institutions, supplemented by interviews and data collected by means of a questionnaire sent to donors and creditors.

\section{CONCLUSION AND RECOMMENDATIONS FOR 2012}

\section{Public finance}

Major progress has been made with execution of the program, enabling the country to pass significant milestones. However, in continuing efforts to increase revenue and control expenditure with the entry into force of the new tax code and implementation of the new structure of the AGID, the authorities opted for centralization of all tax revenue. The effective implementation of the new organizational frameworks testifies to the authorities' desire to substantially reduce the wage bill and keep the number of people on the payroll under control. Nevertheless, there is much to be said for focusing on domestic tax revenue and reducing the heavy dependence on revenue from port fees, particularly with upcoming implementation of the free trade agreements. The reforms undertaken will only have a significant effect if the authorities are willing to implement them in accordance with the intentions underlying them. The indicators for 2012 would improve notably, with marked improvement on the international front.

In the trade sector, we need a policy genuinely geared to reducing the value of imports, which are going to grow over time. The financial capacity of our economic transactors makes us lean in favor of a central purchasing body as a way to reduce costs and lower the prices of staple foods to the benefit of the poor. The country could take advantage of our membership in regional groups, such as the Indian Ocean Commission (COI) or the Common Market for Eastern and Southern Africa (COMESA).

We also need a policy genuinely promoting our export products, so as to further open up the economy. Our fishing agreements should envisage a component in which seafood is processed before being re-exported, as that would improve our exports statistics as well as create jobs. The Qatari project will also help promote our exports. The projections for 2012 indicate that imports will increase due to demand resulting from foreign direct 
investments and the major projects expected. Exports will stagnate due to currently unfavorable world markets.

\section{Energy}

Faced with a deteriorating energy situation, the Government has reasserted its commitment to an in-depth reform of the sector, with the support of the TFPs. The organizational and strategic audit supported by the AfDB (MAMWE) and the WB sector strategy will help clarify the energy sector context and pave the way toward restructuring agreements. However, it would be a good time to explore energy alternatives with a view to reducing our heavy dependence on oil and gas. Thanks to the many ways in which our partners have offered to help and the will shown by the authorities, the sector will post better results in 2012 with a stronger energy supply. Indeed, the review of existing groups and the exploitation of groups supported by Chinese cooperation will result in a more robust energy supply.

\section{Infrastructure}

The outlook for the roads sub-sector has improved thanks to the projects under way or programmed for 2012. In the absence of fresh funding in connection with the "economic citizenship" program (les fonds de la citoyenneté économique), the construction of new roads and the rehabilitation and restructuring of old stretches of highway will depend on contributions from outside donors. There have been major port and airport investments, but not enough to raise the level and quality of the infrastructure to meet needs and demands.

The telecommunications sub-sector faces problems related to obsolete equipment, poorly designed expansion, poor services, and faulty financial management by the principal state operator. On the other hand, the sub-sector is expanding fast and the principal state operator has invested in self-financing and has been able to take advantage of concessionary Chine loans to develop the optical fiber network, the submarine cable for which has already been connected on land but is not yet operational. The authorities have embarked on a process of privatizing part of Comores Telecom and the arrival of the new operator is likely to mean better service at affordable prices.

\section{Water and sanitation}

The Comorian Government has sent a strong signal about its intention to promote the sector, resulting in advocacy and a robust mobilization of donors and creditors. All this will permit an expansion of the water supply network. What is new in 2012 is the readiness of the partners to include rural areas in their projects. Iran has a rural wells equipment program and the UNDP has embarked on a project for protecting water resources from climate change. However, there are quality concerns and it is time to establish potability regulations.

As for sanitation, efforts undertaken in 2011 will continue in 2012. Worth noting is the commitment of the AfDB which has a line for financing sanitation works on each island, associated with the establishment of an appropriate hygiene and sanitation framework. With respect to the private sector, the partners' support for improvements in the business environment is highly beneficial for our country, which has to compete with nearby countries. We need a policy that really supports economic agents by involving the State in setting up zones facilitating foreign direct investment, a policy that genuinely helps local transactors dispose of enough resources to carry out large investments. Obviously, private sector development depends on it becoming competitive enough to respond to the challenges of the liberalized economy and trade to which our country has committed itself. Today Comoros is part of the Free Trade Area COMESA, although it is not yet operational, and, furthermore, we are heading in 2012 toward implementation of the 
Customs Union. Thus, we need to expect an impact on our port fee revenue, so that we should already start looking for mitigating measures.

Particular heed must be paid to agriculture, on which 70 percent of the Comorian population depends. We need to develop plans for each line, concentrating on two or three food crops, such as banana, cassava, and sweet potato. Naturally, market gardening also has potential for development both for local consumption and for exporting to the subregion, but only if our country adopts tight sanitary control laws. All agricultural policies must be accompanied by policies that ensure secure land tenure for farmers. In that context, too, the enabling decrees for the forestry law need to be expedited. The investments under way will improve agricultural output indicators and move toward full coverage of market and staple product needs.

As for livestock, genetic improvement of bovine dairy output through artificial insemination raises hopes of a significant increase in livestock production, as the crossfertilization of cows producing large quantities of milk is on the increase. Much remains to be done in the field of animal health and the same is true of poultry farming, where what is needed is a proactive strategy for mobilizing the funds needed to establish poultry meat and egg enterprises that will eventually cover local needs and substitute the massive imports registered at customs. In 2012, there is going to be an improvement in protein coverage from poultry as well an increased supply of eggs.

Finally, in a third line, dairy, poultry meat and egg produce are markets easy to manage and they may quickly reduce (in at most five years), albeit never drastically, the foreign currency outlays involved in the importing of mass consumption dairy products, frozen chicken pieces, and refrigerated eggs that are often associated with food poisoning epidemics.

Of the lead sectors in Comoros, it is fishing (in its industrial sub-sector) that has by far the greatest potential for development. We recommend that the country engage in a huge marketing and lobbying effort to attract foreign investors, such as the big fishing countries like Japan and the European countries to set up a local industrial fisheries industry to cover both domestic demand and exports, instead of continuing to sign fishing agreements that end up being a well organized way of stripping the country of its principal source of wealth.

A marked increase in fish output is noticeable following the installation of the Qatar private enterprise which has contributed major investments in fishing equipment, in a storage and processing plant, and in training of technical staff. The first impact of those investments will be felt in 2012. 2012 is also expected to bring ongoing regional cooperation supported by the EU, along with a large investment in studies of the fisheries potential, in training of staff, and in financial contributions to pay for local fishermen's equipment.

In tourism, it is time to move beyond rhetorical statements concerning the priority of tourism as an engine of growth and to prepare and actually implement a national tourism policy, taking into account each of the islands' specific characteristics, potential, and advantages. We need a policy to break out of isolation with a transportation sector tailored to the industry's needs, while seeking to appeal to visitors who currently prefer other countries in the sub-region. 


\section{Governance}

With respect to governance, it must be acknowledged that our country is in a precarious situation in which destabilizing elements could still re-emerge. Institutionally, we need to review the rules under which our State operates, so as to ensure true national unity. Problems such as corruption, cronyism, political influence and, not least, the issue of the former FGA are capable of undermining social cohesion unless effective steps are taken to eradicate them. The establishment of decentralization bodies is likely to enhance local, democratic governance.

Our justice system need to increase its credibility with those under its jurisdiction, who never cease to complain about the slow progress of judicial proceedings, the length of time it takes to handle cases. The Supreme Court therefore offers a solution for numerous cases awaiting a ruling.

The organization of communal general elections now scheduled for 2013, while continuing the current memorable developments in our institutional history and the reforms relating to political governance, should complete the process of major political reforms and help place the new institutional framework of the Union of Comoros on a firmer footing, with its emphasis on decentralization, local responsibility, and taking charge, at that level, of economic and social development.

Along those lines, it is necessary to consolidate and complete the political and institutional framework by rendering it more stable over the long term, shoring up the independence of the judiciary and parliament's oversight powers, and consolidating peace and social cohesion, using the resources of the United Nations second generation Peace Building Fund and supplementary resources to be sought as needed.

\section{Education}

The major progress achieved must not let us lose sight of the poor performance of certain parts of this sector. The unfortunately immense and diverse challenges have to do, directly or indirectly, with girl/boy parity, literacy, youth, culture and sports, the access to and quality of teaching at all levels of the system, teachers' qualifications, and the enrollment of those who have dropped out of school or are simply out of school for lack of school infrastructure or supervision.

The rehabilitation and upgrading of schools and training establishments are prerequisites for proper absorption of the contents of the teaching dispenses. Steps should be taken to bring training into line with the labor market, so as to ensure decent jobs. For that, it will be necessary to sign contracts with training institutes and enterprises for regarding courses alternating work with studies.

\section{Health}

Despite the resources made available by a number of partners, the health sector has trouble providing quality services to users and, above all, vulnerable groups. The survey currently under way should give us an idea of the extent to which indicator targets are being met: a prerequisite for policy formulation in the sector. The health sector suffers from management problems that could begin to be solved with regulations for health facilities. Attendance at public health facilities is very low, a state of affairs that should encourage the health authorities to offer quality services by providing health facilities that are well endowed with both medical equipment and medical personnel. Private health facilities 
should be inspected to ensure that they conform to the regulations. Efforts to train specialists also need to continue.

\section{Environment}

Despite the satisfactory results obtained, much remains to be done to win the battle against environmental degradation, where it is a question of achieving rational and sustainable management of the natural resources that constitute means of subsistence for the vast majority of vulnerable populations.

Improving "natural capital" entails adopting measures designed to increase the number of protected areas, restoring the fertility of soils on which so much of the production system depends. It also means reconstituting vegetation cover, which plays an important part for both preserving soil structure and restoring natural habitats.

Bearing in mind the socio-economic and demographic context, initiatives aimed at rational management of the environment must be based, as far as possible, on measures within the reach of the most vulnerable populations, both technologically and as regards their cost. Hence the manifest desire of decision-makers to support small farmers with alternative resources that will enable them to manage natural resources sustainably and better adapt to climate change.

\section{Regarding the programming and execution of programs and projects}

It would be best to rethink the whole process of programming programs and projects around implementation of the PRGS, in order to favor national ownership from the very first level of conception.

Weak project management capacity is noticeable, as well as rigidities in the principal TFPs' disbursement procedures. The absence of real annual work plans establishing what activities have to be done when and incorporating the time frames needed to free up the funds needed for each action is a glaring defect that ought to be corrected through appropriate capacity building. National absorption capacity is still a challenge that needs underscoring.

\section{By way of specific recommendations:}

\section{Indicator management}

It is obvious that since the EIM (2004), the MICS (2005) and the RGPH (2003), no major survey has been conducted to shape the PRGS. Yet, monitoring and evaluating require the existence of those indicators, in the framework of the central mandate assigned to the entities producing the data relating to them. Major surveys demand considerable funding, which needs to be raised from the development partners. From this angle, the actions needed for the mechanism to work more effectively will $b$ directed at improving the workings of the National Statistics Department/INSED and corresponding services on the islands. They would mean boosting personnel for in-house needs and for placing at the disposal of the other administrations, as well as for strengthening and revitalizing the planning departments on each of the islands, training them in the methodology of data collection and processing and publication of findings. 


\section{Overall workings of the mechanism}

It is recommended that the mandate and the main tasks assigned to the bodies involved in the institutional mechanism be reframed, so as to enhance performance and the effectiveness of their actions. In particular the GTS and COPSED need to have their tasks redefined.

The development steering, planning, and monitoring and evaluation committees (COPSED) are the bodies responsible for producing key information for monitoring and evaluation of the Poverty Reduction and Growth Strategy (PRGS) on the islands. In particular, they work closely with the Sectoral Technical Groups for planning, implementing, monitoring and evaluating development programs and projects. 